University of South Florida

DIGITAL COMMONS

Digital Commons @ University of

@ UNIVERSITY OF SOUTH FLORIDA

South Florida

USF Patents

June 2008

\title{
Connective tissue growth factor
}

Gary R. Grotendorst

Douglass M. Bradham, Jr.

Follow this and additional works at: https://digitalcommons.usf.edu/usf_patents

\section{Recommended Citation}

Grotendorst, Gary R. and Bradham, Jr., Douglass M., "Connective tissue growth factor" (2008). USF

Patents. 597.

https://digitalcommons.usf.edu/usf_patents/597

This Patent is brought to you for free and open access by Digital Commons @ University of South Florida. It has been accepted for inclusion in USF Patents by an authorized administrator of Digital Commons @ University of South Florida. For more information, please contact digitalcommons@usf.edu. 
(12) United States Patent Grotendorst et al. $\begin{array}{lr}\text { (10) Patent No.: } & \text { US 7,384,634 B2 } \\ \text { (45) Date of Patent: } & * \text { Jun. 10, } 2008\end{array}$

\section{(54) CONNECTIVE TISSUE GROWTH FACTOR}

(75) Inventors: Gary R. Grotendorst, Miami, FL (US); Douglass M. Bradham, Jr., Baltimore, MD (US)

(73) Assignee: University of South Florida, Tampa, FL (US)

(*) Notice: Subject to any disclaimer, the term of this patent is extended or adjusted under 35 U.S.C. 154(b) by 733 days.

This patent is subject to a terminal disclaimer.

(21) Appl. No.: 10/338,587

(22) Filed: Jan. 7, 2003

\section{Prior Publication Data}

US 2004/0005319 A1 Jan. 8, 2004

\section{Related U.S. Application Data}

(60) Continuation of application No. 09/054,363, filed on Apr. 2, 1998, now abandoned, which is a division of application No. 08/459,717, filed on Jun. 2, 1995, now Pat. No. 5,770,209, which is a continuation-in-part of application No. 08/386,680, filed on Feb. 10, 1995 , now Pat. No. 5,585,270, which is a division of application No. 08/167,628, filed on Dec. 14, 1993, now Pat. No. 5,408,040, which is a continuation of application No. 07/752,427, filed on Aug. 30, 1991, now abandoned.

(51) Int. Cl. A61K 39/395 (2006.01) $A 61 K 38 / 18 \quad(2006.01)$

(52) U.S. Cl. ................ 424/145.1; 424/158.1; 530/399

(58) Field of Classification Search .................... None See application file for complete search history.

\section{References Cited}

\section{U.S. PATENT DOCUMENTS}

\begin{tabular}{|c|c|c|c|}
\hline $4,806,523$ & A & 89 & 수 \\
\hline $4,808,402$ & A & $2 / 1989$ & Leibovich et al. ....... 424/78.06 \\
\hline $5,094,941$ & A & 3/1992 & Hart ....................... 435/7.9 \\
\hline $5,147,294$ & A & $9 / 1992$ & Smith et al. ....... \\
\hline $5,149,691$ & A & $9 / 1992$ & Rutherford .. \\
\hline 6,630 & A & $10 / 1994$ & Laurencin et al. \\
\hline $5,399,361$ & A & $3 / 1995$ & Song et al. ................ 424/ \\
\hline $5,408,040$ & A & $4 / 1995$ & Grotendorst et al. ....... 530 \\
\hline $5,418,135$ & A & $5 / 1995$ & 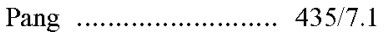 \\
\hline $5,693,607$ & A & $12 / 1997$ & Segarini et al. $\ldots \ldots \ldots \ldots \ldots . \quad 514 / 2$ \\
\hline $5,770,209$ & A & $6 / 1998$ & Grotendorst et al. .... 424/198.1 \\
\hline 3,187 & A & $7 / 1998$ & Grotendorst et al. $\ldots . .4424 / 158$. \\
\hline $5,837,258$ & A & $11 / 1998$ & Grotendorst et al. .... $424 / 198.1$ \\
\hline $6,331,298$ & $\mathrm{~B} 1 *$ & $12 / 2001$ & Ferguson et al. ......... 424/85.1 \\
\hline $7,105,305$ & $\mathrm{~B} 2 *$ & $9 / 2006$ & Williams et al. ........... 435/7.1 \\
\hline
\end{tabular}

\section{OTHER PUBLICATIONS}

Abou-Shady et al. "Connective Tissue Growth Factor in Human Liver Cirrhosis," Liver. 20:296-304 (2000) Munksgaard.
Allen et al. "Enhanced Insulin-Like Growth Factor Binding ProteinRelated Protein 2 (Connective Tissue Growth Factor) Expression in Patients with Idiopathic Pulmonary Fibrosis and Pulmonary Sarcoidosis," Am. J. Respir: Cell Mol. Biol. 21:693-700 (1999).

Bradham et al. "Connective Tissue Growth Factor: A Cysteine-rich Mitogen Secreted by Human Vascular Endothelial Cells is Related to the SRC-induced Immediate Early Gene Product CEF-10," Journal of Cell Biology 114(6):1285-1294 (1991) Rockefeller University Press.

Chen et al. "CTGF Expression is Induced by TGF- $\beta$ in Cardiac Fibroblasts and Cardiac Myocytes: a Potential Role in Heart Fibrosis." J Mol Cell Cardiol, 32:1805-1819 (2000).

di Mola et al. "Connective Tissue Growth Factor Is a Regulator for Fibrosis in Human Pancreatitis," Annals of Surgery 230(1):63-71 (1999) Lippincott Williams \& Wilkins, Inc.

Duncan et al. "Connective Tissue Growth Factor Mediates Transforming Growth Factor $\beta$-induced Collagen Synthesis: Down-Regulation by camp," FASEB J. 13:1774-1786 (1999).

Frazier and Grotendorst. "Expression of Connective Tissue Growth Factor mRNA in the Fibrous Stroma of Mammary Tumors," Int. $J$. Biochem Cell Biol. 29:153-161 (1997) Elsevier Science Ltd.

Frazier et al. "Stimulation of Fibroblast Cell Growth, Matrix Production, and Granulation Tissue Formation by Connective Tissue Growth Factor," J Invest Dermatol 107:404-41 1 (1996) Society; for investigative Dermatology, Inc.

Grotendorst. "Connective Tissue Growth Factor: A Mediator of TGF- $\beta$ Action on Fibroblasts," Cytokine \& Growth Factor Reviews 8(3):171-179 (1997) Elsevier Science Ltd.

Igarashi et al. "Differential Expression of Connective Tissue Growth Factor Gene in Cutaneous Fibrohistiocytic and Vascular Tumors," $J$ Cutan Pathol 25:143-148 (1998) Munksgaard.

Igarashi et al. "Connective Tissue Growth Factor Gene Expression in Tissue Sections from Localized Scleroderma, Keloid, and Other Fibrotic Skin Disorders," I Invest Dermatol 106:729-733 (1996) Society; for Investigative Dermatology, Inc.

Ito et al. "Expression of Connective Tissue Growth Factor in Human Renal Fibrosis," Department of Pathology, University of Amsterdam, pp. 853-861, (1997) International Socieity of Nephrology.

Kasaragod et al. "Connective Tissue Growth Factor Expression in Pediatric Myofibroblastic Tumors," Pediatric and Developmental Pathology 4:37-45 (2001) Society for Pediatric Pathology.

Kikuchi et al. "Expression of Fibrogenic Cytokines in Desmoplastic Malignant Melanoma," British Journal of Dermatology 139:192-197 (1998) British Association of Dermatologists.

Lasky et al. "Connective Tissue Growth Factor mRNA Expression is Upregulated in Bleomycin-induced Lung Fibrosis," Am J Physiol 275:L365-L37 1 (1998) American Physiological Society.

$$
\text { (Continued) }
$$

Primary Examiner-Lorraine Spector (74) Attorney, Agent, or Firm-DLA Piper US LLP

\section{ABSTRACT}

The present invention provides a novel polypeptide, Connective Tissue Growth Factor (CTGF), polynucleotides encoding CTGF and polynucleotides regulating CTGF expression. The invention also provides agents that modulate CTGF and therapeutic methods for using the agents. Also provided are diagnostic methods for using CTGF and assays for identifying agents which affect the expression of CTGF polynucleotide. 


\section{US 7,384,634 B2}

Page 2

\section{OTHER PUBLICATIONS}

Lee and Joo. "Role of Transforming Growth Factor- $\beta$ in Transdifferentiation and Fibrosis of Lens Epithelial Cells," Invest Ophthal \& Vis Sci 40:2025-2032 (1999) Association for Research in Vision and Ophthalmology.

Mori et al. "Role and Interaction of Connective Tissue Growth Factor with Transforming Growth Factor- $\beta$ in Persistent Fibrosis: A Mouse Fibrosis Model." J. Cellular Physiology 181:153-159 (1999) WileyLiss, Inc.

Oemar et al. "Human Connective Tissue Growth Factor is Expressed in Advanced Atherosclerotic Lesions," Circulation 95:831-839 (1997) American Heart Association, Inc.

Ohnishi et al. "Increased Expression of Connective Tissue Growth Factor in the Infared Zone of Experimentally Induced Myocardial Infarction in Rats," J Mol Cell Cardiol 30:2411-2422 (1998) Academic Press.

Paradis et al. "Expression of Connective Tissue Growth Factor in Experimental Rat and Human Liver Fibrosis," Hepatology 30:968976 (1999).

Querfeld et al. "Pseudoscleroderma Associated with Lung Cancer: Correlation of Collagen Type I and Connective Tissue Growth Factor Gene Expression," British Journal of Dermatology 142:1228-1233 (2000) British Association of Dermatologists.

Sato et al. "Serum Levels of Connective Tissue Growth Factor Are Elevated in Patients with Systemic Sclerosis: Association with Extent of Skin Sclerosis and Severity of Pulmonary Fibrosis," Journal of Rheumatology 17:149-154 (1998).

Shi-wen et al. "Autocrine Overexpression of CTGF Maintains Fibrosis: RDA Analysis of Fibrosis Genes in Systemic Sclerosis," Experimental Cell Research 259:213-224 (2000) Academic Press.

Shimo et al. "Connective Tissue Growth Factor Induces the Proliferation, Migration, and Tube Formation of Vascular Endothelial Cells In Vitro, and Angiogenesis In Vivo," J. Biochem. 126:137-145 (1999) Japanese Biochemical Society.

Vorwek et al. "CTGF (IGFBP-rP2) Is Specifically Expressed in Malignant Lymphoblasts of patients with Acute Lymphoblastic Leukaemia (ALL)," British Journal of Cancer 68(6):756-760 (2000) Cancer Research Campaign.
Wenger et al. "Expression and Differential Regulation of Connective Tissue Growth Factor in Pancreatic Cancer Cells," Oncogene 18:1073-1080 (1999) Stockton Press.

Bang et al., "Cyclic AMP induces transforming growth factor $\beta 2$ gene expression and growth arrest in the human androgen-independent prostate carcinoma cell line PC-3," Proc. Natl. Acad. Sci. USA, 89:3556-3560 (1992).

Grotendorst et al., "A Novel Transforming Growth Factor $\beta$ Response Element Controls the Expression of the Connective Tissue Growth Factor Gene," Cell Growth and Differentiation, 7(4):469-480 (1996). Igarashi et al., "Regulation of Connective Tissue Growth Factor Gene Expression on Human Skin Fibroblasts and During Wound Repair," Molecular Biology of the Cell, 4(6):637-645 (1993).

Inagaki et al., "Transforming Growth Factor- $\beta$ stimulates $\alpha 2(\mathrm{I})$ Collagen Gene Expression through a cis-Acting Element That Contains an Sp1-binding Site," J. Biol. Chem., 269(20):14828-14834 (1994). Keeton et al., "Identification of Regulatory Sequences in the Type 1 Plasminogen Activator Inhibitor Gene Responsive to Transforming Growth Factor $\beta$," Journal of Biological Chemistry, 266(34):2304823052 (1991).

Rundhaug and Nettesheim, "Growth Regulation of Primary Rat Tracheal Epithelial Cell Cultures by Endogenous Transforming growth Factor- $\beta s$," J. Cellular Physiology, 155(3):483-493 (1993).

Ryseck et al., "Structure, Mapping, and Expression of fisp-12, A Growth Factor-Inducible Gene Encoding a Secreted Cysteine-Rich Protein," Cell Growth and Differentiation, 2(5):225-233 (1991).

Wilson et al., " $2.2 \mathrm{Mb}$ of contiguous nucleotide sequence from chromosome III of C. elegance," Nature, 368(6466):32-38 (1994).

Bradham et al., "Connective Tissue Growth Factor: a Cysteine-rich Mitogen Secreted by Human Vascular Endothelial cells is Related to the SRC-induced Immediate Early Gene Product CEF-10," J. Cell Biology, 114(6):1285-1294 (1991).

Oemar et al., "Connective Tissue Growth Factor, Friend or Foe?" Arteriosclerosis, Thrombosis, and Vascular Biology, 17(8):14831489 (1997)

Shimokado et al., Cell 43:277-286, Nov. 1985.

Campochiaro et al., Exp. Eye Res. 49:217-227, 1989.

Matsuoka et al., Proc. Nat. Acad. Sci. 86:4416-4420, Jun. 1989

* cited by examiner 


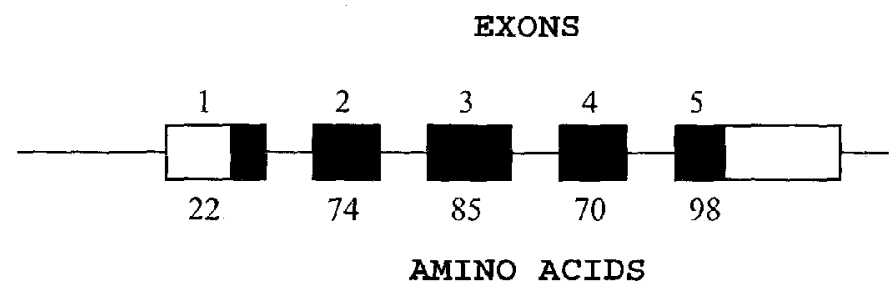

FIG. 1A

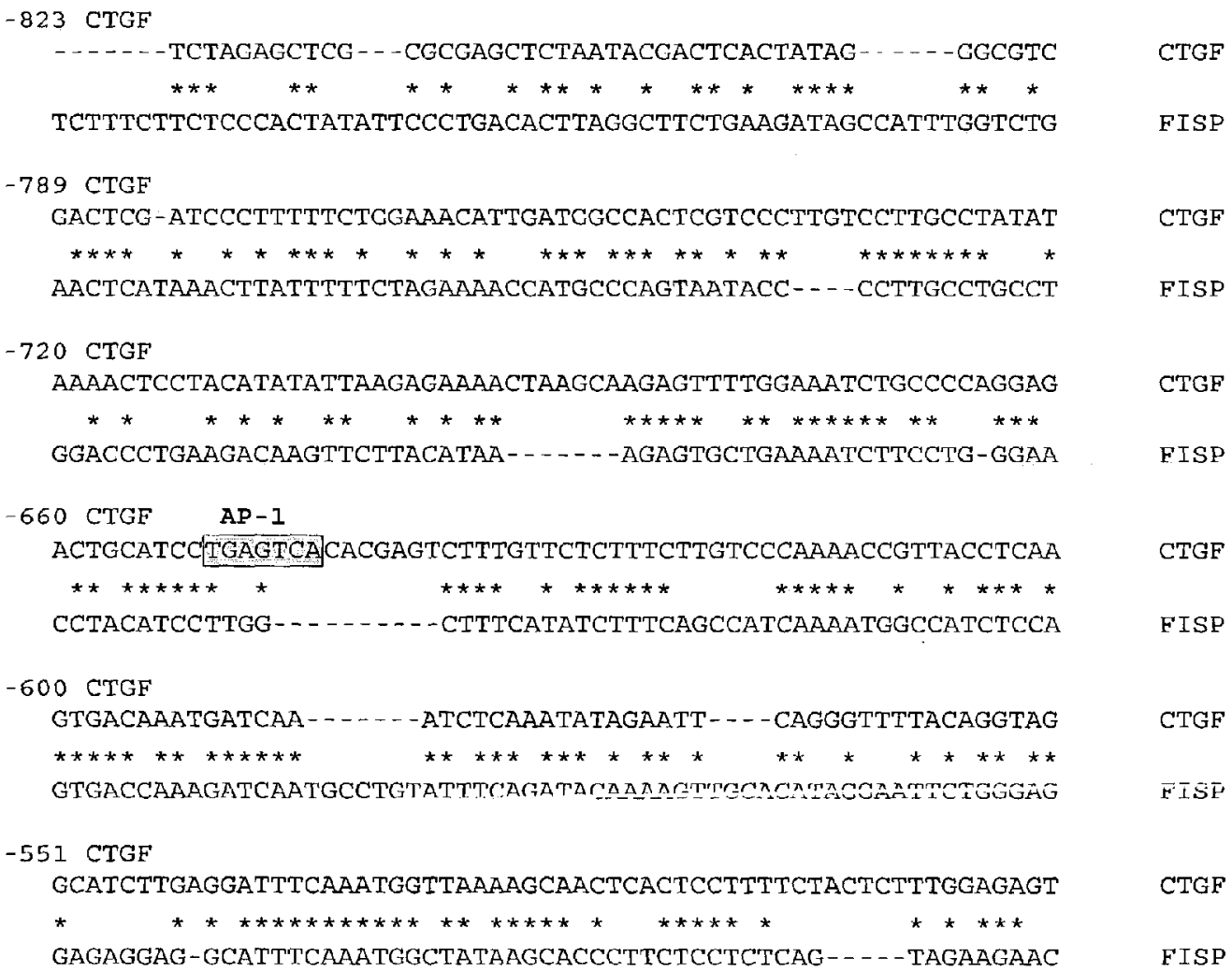

FIG. 1B 
-823 TCTAGAGCTCGCGCGAGCTCTAATACGACTCACTATAGGGCGTCGACTCGATCCCTTTTT

- 763 CTGGAAACATTGATGGCCACTCGTCCCTTGTCCTTGCCTATATAAAACTCCTACATATAT

-703 tAAGAGAAAACTAAGCAAGAgTtTtgGAaATCTGCCCCAGGAGACTGCATCCTGAGTCAC

$A P-1$

-643 ACGAGTCTTTGTTCTCTTTCTTGTCCCAAAACCGTTACCTCAAGTGACAAATGATCAAAT

-583 CTCAAATATAGAATTCAGGGTTTTACAGGTAGGCATCTTGAGGATTTCAAATGGTTAAAA

-523 GCAACTCACTCCTTTTCTACTCTTTGGAGAGTTTCAAGAGCCTATAGCCTCTAAAACGCA

463 AATCATTGCTAAGGGTTGGGGGGGAGAAACCTTTTCGAATTTTTTAGGAATTCCTGCTGT

-403 TTGCCTCTTCAGCTACCTACTTCCTAAAAAGGATGTATGTCAGTGGACAGAACAGGGCAA CAIG box

-343 ACTTATTCGAAAAAGAAATAAGAAATAATTGCCAGTGTGTTTATAAATGATATGAATCAG

AP -1

-283 GAGTGGTGCGAAGAGGATAGGAAAAAAAAATTCTATTTGGTGCTGGAAATACTGCGCTTT

-223 TTTTTTCCTTTTTTTTTTTTTCTGTGAGCTGGAGTGTGCCAGCTTTTTCAGACGGAGGAA NF-1 like

-163 TGCTGAGTGTCAAGGGGTCAGGATCAATCCGGTGTGAGTTGATGAGGCAGGAAGGTGGGG TIE-like

-103 AggAatgCGAGgAATGTCCCTGTTTgTGTAGGACTCCATTCAGCTCATTGGCGAGCCGCG CATbOX

-43 GCCGCCCGGAGCGTATAAAAGCCTCGGGCCGCCCGCCCCAAACTCACACAACAACTCTTC SP-1 TATABOX SP-1 +1

17 CCCGCTGAGAGGAGACAGCCAGTGCGACTCCACCCTCCAGCTCGACGGCAGCCGCCCCGG

77 CCGACAGCCCCGAGACGACAGCCCGGCGCGTCCCGGTCCCCACCTCCGACCACCGCCAGC

137 GCTCCAGGCCCCGCGCTCCCCGCTCGCCGCCACCGCGCCCTCCGCTCCGCCCGCAGTGCC

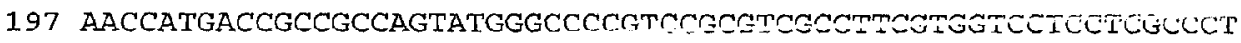
$\begin{array}{llllllllllllllllllll}M & \mathbf{T} & \mathbf{A} & \mathbf{A} & \mathbf{S} & \mathbf{M} & \mathbf{G} & \mathbf{P} & \mathbf{V} & \mathbf{A} & \mathbf{V} & \mathbf{A} & \mathbf{F} & \mathbf{V} & \boldsymbol{V} & \boldsymbol{L} & \mathbf{L} & \mathbf{A} & \mathbf{L}\end{array}$ 257 CTGCAGCCGGGTAAGCGCCGGGAGCCCCCGCTGCGGCCGGCGGCTGCCAGGGAGGGACTC

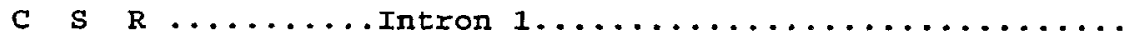
317 GGGGCCGGCCGGGGAGGGCGTGCGCGCCGACCGAGCGCCGCTGACCGCCCTGTCCTCCCT $\ldots \ldots \ldots \ldots \ldots \ldots \ldots \ldots \ldots \ldots \ldots \ldots \ldots \ldots \ldots \ldots \ldots \ldots \ldots \ldots \ldots \ldots \ldots \ldots \ldots \ldots \ldots \ldots \ldots \ldots$ 
377 GCAGCCGGCCGTCGGCCAGAACTGCAGCGGGCCGTGCCGGTGCCCGGACGAGCCGGCGCC $\begin{array}{llllllllllllllllllllll}\ldots & \text {. } & \text { A } & \text { A } & \text { V } & G & Q & \mathbb{N} & C & \mathbf{S} & G & \mathbf{P} & \mathbf{C} & \mathbf{R} & \mathbf{C} & \mathbf{P} & \mathbf{D} & \mathbf{E} & \mathbf{P} & \mathrm{A} & \mathbf{P}\end{array}$ 437 GCGCTGCCCGGCGGGCGTGAGCCTCGTGCTGGACGGCTGCGGCTGCTGCCGCGTCTGCGC $\begin{array}{llllllllllllllllllll}R & C & P & A & G & V & S & \text { L } & \text { V } & \text { L } & \text { D } & G & \text { C } & G & \text { C } & C & R & \text { V } & C & A\end{array}$ 497 CAAGCAGCTGGGCGAGCTGTGCACCGAGCGCGACCCCTGCGACCCGCACAAGGGCCTCTT $\begin{array}{llllllllllllllllllll}K & Q & \text { L } & G & \mathbf{E} & \mathbf{L} & \mathbf{C} & \mathbf{T} & \mathbf{E} & \mathbf{R} & \mathbf{D} & \mathbf{P} & \mathbf{C} & \mathbf{D} & \mathbf{P} & \mathbf{H} & \mathbf{K} & \mathbf{G} & \mathbf{L} & \mathbf{F}\end{array}$ 557 CTGTGACTTCGGCTCCCCGGCCAACCGCAAGATCGGCGTGTGCACCGGTAAGACCCGCAG $\begin{array}{lllllllllllllllllll}C & D & F & G & S & P & A & N & R & K & I & G & V & C & T & \ldots & \text { Intron } & 2 \ldots\end{array}$

617 CCCCCACCGCTAGGTGTCCGGCCGCCTCCTCCCTCACGCCCACCCGCCCGCTGGAAAAAG

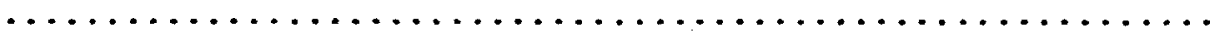

677 AAACCGCTCGGACTGAGTTTCTTTCTCCAGCTGCTGCCAGCCCGCCCCCTGCAGCCCAGA ..............................

737 TCCCAACTCGCATCCCTGACGCTCTGGATGTGAGAGTGCCCCAATGCCTGACCTCTGCAT .............................

797 CCCCCACCCCTCTCTTCCCTTCCTCTTCTCCAGCCAAAGATGGTGCTCCCTGCATCTTCG $\ldots \ldots \ldots \ldots \ldots \ldots \ldots \ldots \ldots \ldots \ldots \ldots \ldots$

857 GTGGTACGGTGTACCGCAGCGGAGAGTCCTTCCAGAGCAGCTGCAAGTACCAGTGCACGT $\begin{array}{llllllllllllllllllll}G & G & T & V & Y & R & S & G & E & S & F & Q & S & S & C & \mathbb{R} & Y & Q & C & T\end{array}$

917 GCCTGGACGGGGCGGTGGGCTGCATGCCCCTGTGCAGCATGGACGTTCGTCTGCCCAGCC $\begin{array}{llllllllllllllllllll}C & I & D & G & A & V & G & C & M & \mathbf{P} & \mathbf{L} & \mathbf{C} & \mathbf{S} & \mathbf{M} & \mathbf{D} & \mathbf{V} & \mathbf{R} & \mathbf{I} & \mathbf{P} & \mathbf{S}\end{array}$

977 CTGACTGCCCCTICCCGAGGAGGGTCAAGCTGCCCGGGAAATGCTGCGAGGAGTGGGTGT $\begin{array}{llllllllllllllllllll}\mathbf{P} & \mathbf{D} & \mathbf{C} & \mathbf{P} & \mathbf{F} & \mathbf{P} & \mathbf{R} & \mathbf{R} & \mathbf{V} & \mathbf{K} & \mathbf{L} & \mathbf{P} & \mathbf{G} & \mathbf{K} & \mathbf{C} & \mathbf{C} & \mathbf{E} & \mathbf{E} & \mathbf{W} & \mathbf{V}\end{array}$

1037 GTGACGAGCCCAAGGACCAAACCGTGGTTGGGCCTGCCCTCGCGGGTGAGTCGAGTCTTC

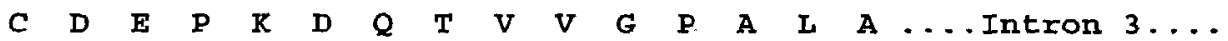

1097 CTCTAAGTCAGGGTCGTGATTCTCTCCCAGGGAGGGAGTCCTAACTGTGCCGACCGAACG

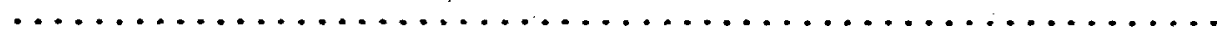

1157 GGGAAATACCTTATCAGGCGTTTTACATGGTGTTTGTGTGCTCTGCTCTCGCAGCTTACC

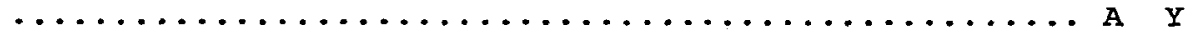

1217 GACTGGAAGACACGTTTGGCCCAGACCCAACTATGATTAGAGCCAACTGCCTGGTCCAGA $\begin{array}{llllllllllllllllllll}\mathbf{R} & \mathbf{L} & \mathbf{E} & \mathbf{D} & \mathbf{T} & \mathbf{F} & \mathbf{G} & \mathbf{P} & \mathbf{D} & \mathbf{P} & \mathbf{T} & \mathbf{M} & \mathbf{I} & \mathbf{R} & \mathbf{A} & \mathbf{N} & \mathbf{C} & \mathbf{I} & \mathbf{V} & \mathbf{Q}\end{array}$

1277 CCACAGAGTGGAGCGCCTGTTCCAAGACCTGTGGGATGGGCATCTCCACCCGGGTTACCA

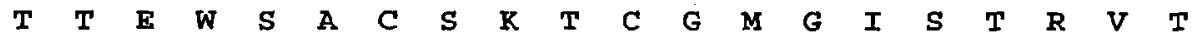

1337 ATGACAACGCCTCCTGCAGGCTAGAGAAGCAGAGCCGCCTGTGCATGGTCAGGCCTTGCG $\begin{array}{llllllllllllllllllll}N & D & N & A & S & C & R & I & E & K & Q & S & R & L & C & M & V & R & P & C\end{array}$

1397 AAGCTGACCTGGAAGAGAACATTAAGGTACATGTTCTGCTCCTATTAACTATTTTTCACA $E \quad A \quad D \quad I \quad E \quad E \quad N \quad I \quad K \ldots \ldots \ldots \ldots$ Intron $4 \ldots \ldots \ldots$

1457 GGAAAAACAGTGGATAGGACCCAACTTAGGGCTCTTGCACGCTTGTTAGTATAAGCCCGT

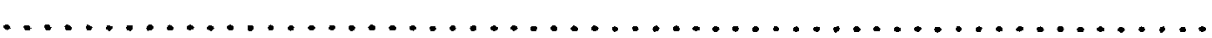

1517 TATCTCCAAAACTATCTAACCATTGAGCTGTTTTGCTGGAATGAGAGCTTGTSTARTAEC

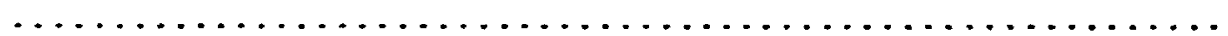

1577 AACCACCAGTTTTCCACTACGAAATCTTCCACAGGGTTAGTTAATTCAAGACATTCCAAG

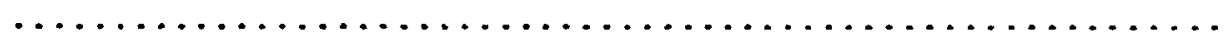

1637 AGAGGCTCTGGCTATTTTTGGACATAGCAAATGAGACTCAAACTTCCTCCCCTCAAAATA FIG. 1C (con't) 
1697 TAAACAGAAGTCAGACAACAGAAGACTAAAACACAGAGGGTTGAAGAAAGCCACTCCTCT

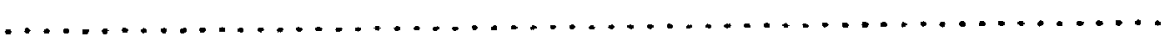

1757 TGTAGAGTCGCTGATTTTTTTTTTICCTCTCTCTTTTCCCTTGTCTTCCTTAGAAGGGCA

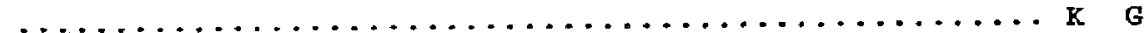

1817 AAAAGTGCATCCGTACTCCCAAAATCTCCAAGCCTATCAAGTTTGAGCTTTCTGGCTGCA $\begin{array}{llllllllllllllllllll}K & K & C & I & R & T & P & K & I & S & K & P & I & K & F & E & L & S & G & C\end{array}$

1877 CCAGCATGAAGACATACCGAGCTAAATTCTGTGGAGTATGTACCGACGGCCGATGCTGCA $\begin{array}{llllllllllllllllllll}\mathbf{T} & \mathbf{S} & \mathbf{M} & \mathbf{K} & \mathbf{T} & \mathbf{Y} & \mathbf{R} & \mathbf{A} & \mathbf{K} & \mathbf{F} & \mathbf{C} & \mathbf{G} & \mathbf{V} & \mathbf{C} & \mathbf{T} & \mathbf{D} & \mathbf{G} & \mathbb{R} & \mathbf{C} & \mathbf{C}\end{array}$

1937 CCCCCCACAGAACCACCACCCTGCCGGTGGAGTTCAAGTGCCCTGACGGCGAGGTCATGA $\begin{array}{llllllllllllllllllll}\mathbf{T} & \mathbf{P} & \mathbf{H} & \mathbf{R} & \mathbf{T} & \mathbf{T} & \mathbf{T} & \mathbf{L} & \mathbf{P} & \mathbf{V} & \mathbf{E} & \mathbf{F} & \mathbf{R} & \mathbf{C} & \mathbf{P} & \mathbf{D} & \mathbf{G} & \mathbf{E} & \mathbf{V} & \mathbf{M}\end{array}$ 1997 AGAAGAACATGATGTTCATCAAGACCTGTGCCTGCCATTACAACTGTCCCGGAGACAATG

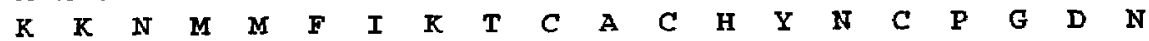
2057 ACATCTTTGAATCGCTGTACTACAGgAAGATGTACGgAGACATGGCATGAAGCCAGAGAG $\begin{array}{llllllllllllllll}\mathbf{D} & \mathbf{I} & \mathbf{F} & \mathbf{E} & \mathbf{S} & \mathbf{L} & \mathbf{Y} & \mathbf{Y} & \mathbf{R} & \mathbf{K} & \mathbf{M} & \mathbf{Y} & \mathbf{G} & \mathbf{D} & \mathbf{M} & \mathbf{A}\end{array}$

2117 TGAGAGACATTAACTCATTAGACTGGAACTTGAACTGATTCACATCTCATTTTTCCGTAA 2177 AAATGATTTCAGTAGCACAAGTTATTTAARTCTGTTTTTCTAACTGGGGGAAAAGATTCC 2237 CACCCAATTCAAAACATTGTGCCATGTCAAACAAATAGTCTATCTTCCCCAGACACTGGT 2297 TTGAAGAATGTTAAGACTTGACAGTGGAACTACATTAGTACACAGCACCAGAATGTATAT 2357 TAAGGTGTGGCTTTAGGAGCAGTGGGAGGGTACCGGCCCGGTTAGTATCATCAGATCGAC 2417 TCTTATACGAGTAATATGCCTGCTATTTGAAGTGTAATTGAGAAGGAAAATTTTAGCGTG 2477 CTCACTGACCTGCCTGTAGCCCCAGTGACAGCTAGGATGTGCATTCTCCAGCCATCAAGA 2537 GACTGAGTCAAGTTGTTCCTTAAGTCAGAACAGCAGACTCAGCTCTGACATTCTGATTCG 2597 AATGACACTGTTCAGGAATCGGAATCCTGTCGATTAGACTGGACAGCTTGTGGCAAGTGA 2657 ATTTGCCTGTAACAAGCCAGATTTTTTAAAATTTATATTGTAAATATTGTGTGTGTGTGT 2717 GTGTGTGTATATATATATATATATGTACAGTTATCTAAGTTAATTTAAAGTTGTTTGTGC 2777 CTTTTTATTTTTGTTTTTAATGCTTTGATATTTCAATGTTAGCCTCAATTTCTGAACACC 2837 ATAGGTAGAATGTAAAGCTTGTCTGATCGTTCAAAGCATGAAATGGATACTTATATGGAA 2897 ATTCTGCTCAGATAGAATGACAGTCCGTCAAAACAGATTGTTTGCAAAGGGGAGGCATCA 2957 GTGTCTTGGCAGGCTGATTTCTAGGTAGGAAATGTGGTAGCTCACGTTTAATGAACAAAT 3017 GGCCTTATTAAAAACTGAGTGACTCTATATAGCTGATCAGTTTTTCACCTGAAGCATTTG 3077 TTTCTACTTTGATATGACTGTTTTTCGACAGTTTATTTGTTGAGAGTGTGACCAAAAGTT 3137 ACATGTTTGCACCTTTCTAGTTGAAAATAAAGTGTATATTTTTTCTATAAAGGGCTTGGT 3197 TATTCATTTATCCTTCTAAACATTTCTGAGTTTTCTTGAGCATAAATAGGAAGTTCTTAT 3257 TAATCATAAGATAATTCACCAATAATTTTCTAAATATCTTTAATTATTCTATACATTAAT 3317 AAATTGATTATTCCATAGAATTTTATGTAAACATACTTCACACTGAATCAAGTATCACA 3377 GACTTGCAGGCATA 
Hours after

TGF $\beta$ removal

$\begin{array}{llllllll}C & 0 & 1 & 4 & 8 & 24 & 30 & 48\end{array}$

CTGF

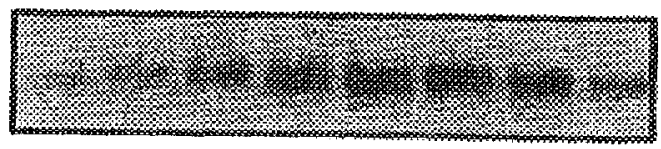

FIG. $2 A$
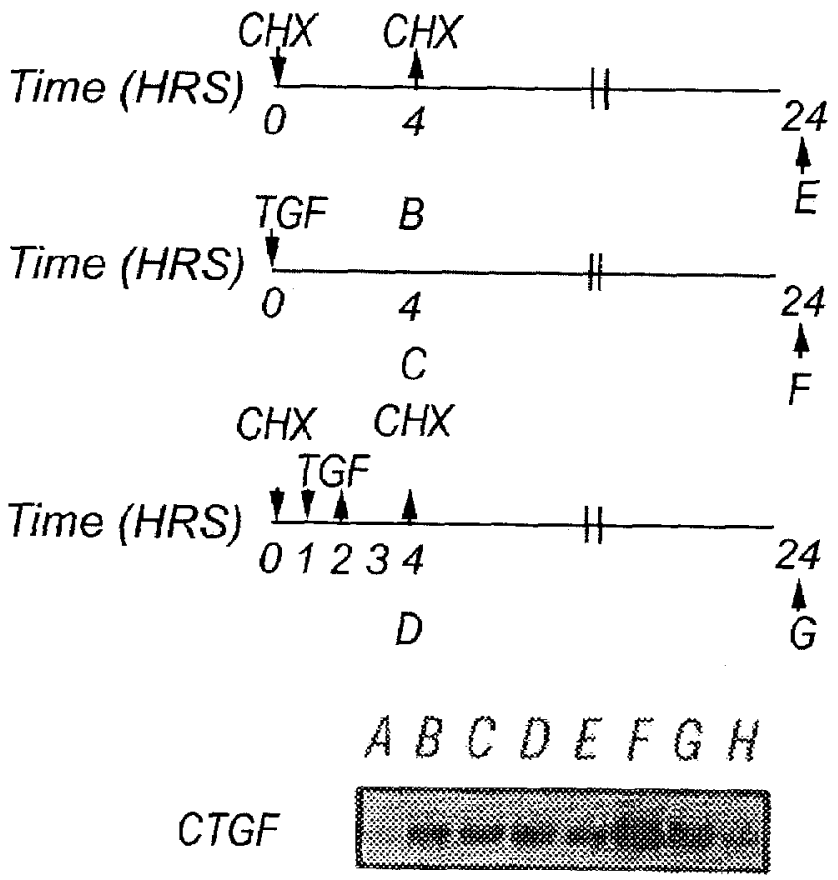

FIG. 2B

TGFP (TÜng/mi)

Puromycin $(100 \mu \mathrm{g} / \mathrm{ml})$

Anisomycin (10ug/ml)

CTGF
$-+-+-+$

$-++-$

$-\quad+-++$

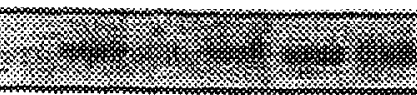

FIG. $2 C$ 

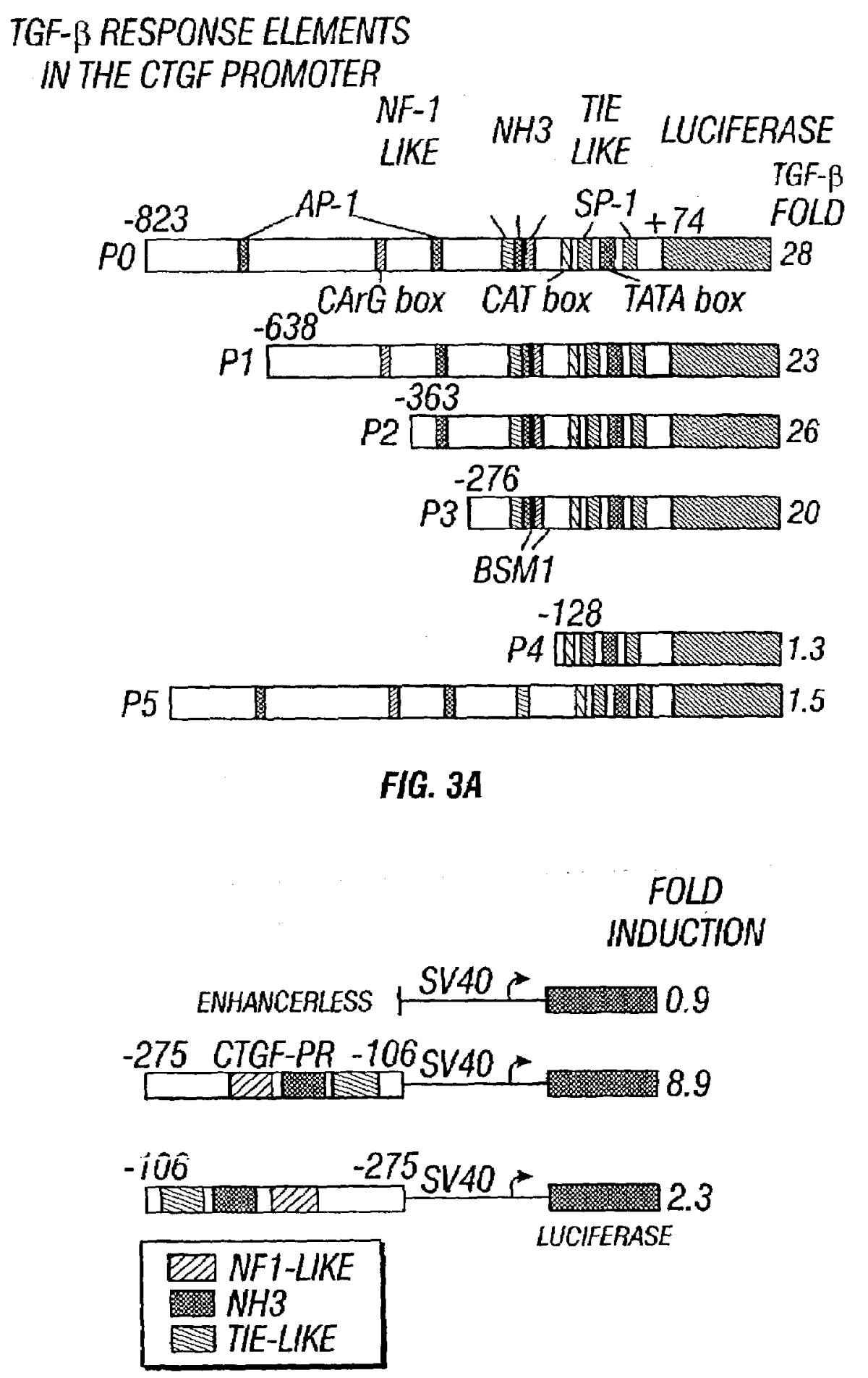

FIG. 3B 

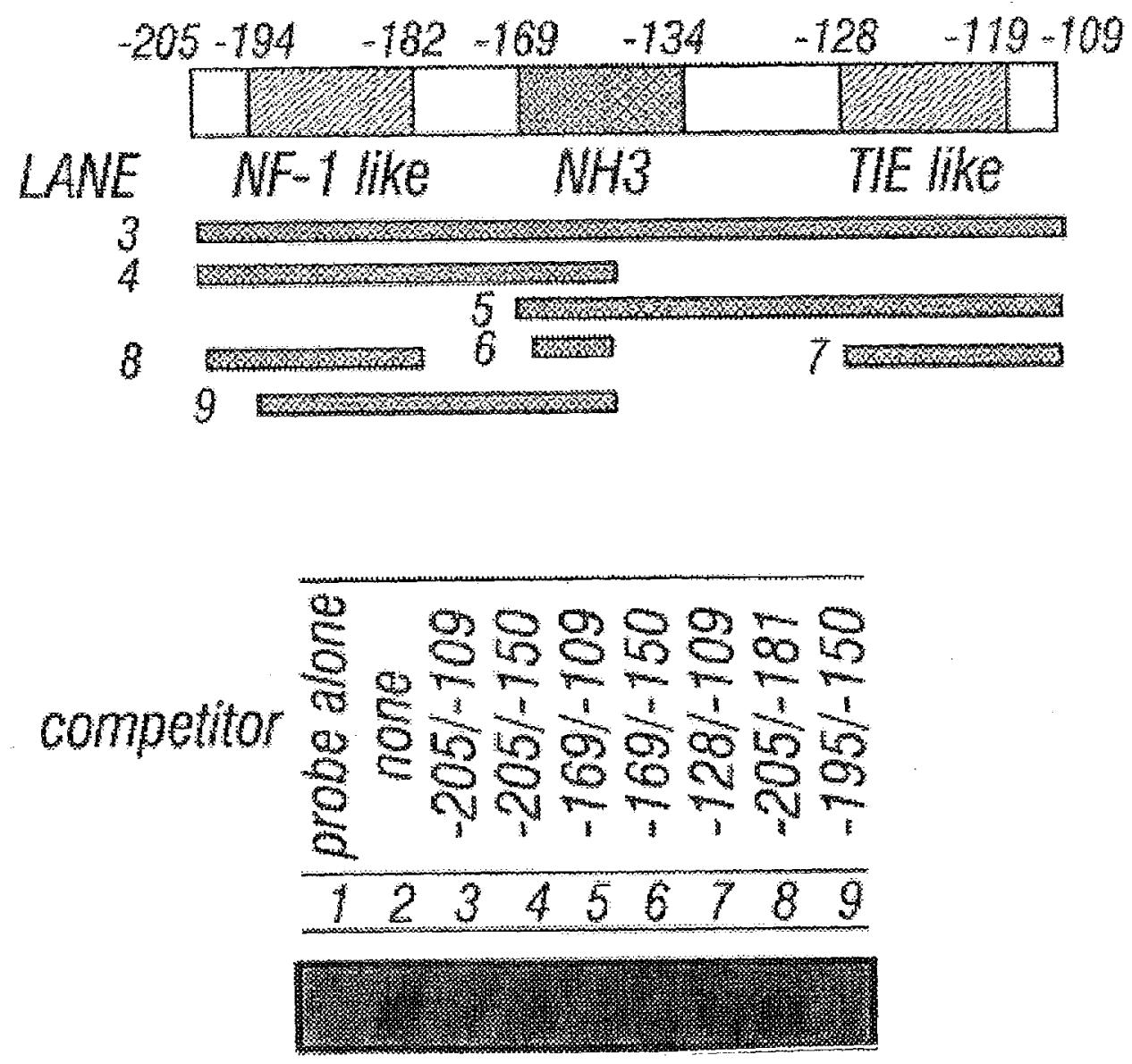

FIG. 4 
U.S. Patent Jun. 10, 2008 Sheet 9 of 15

US 7,384,634 B2
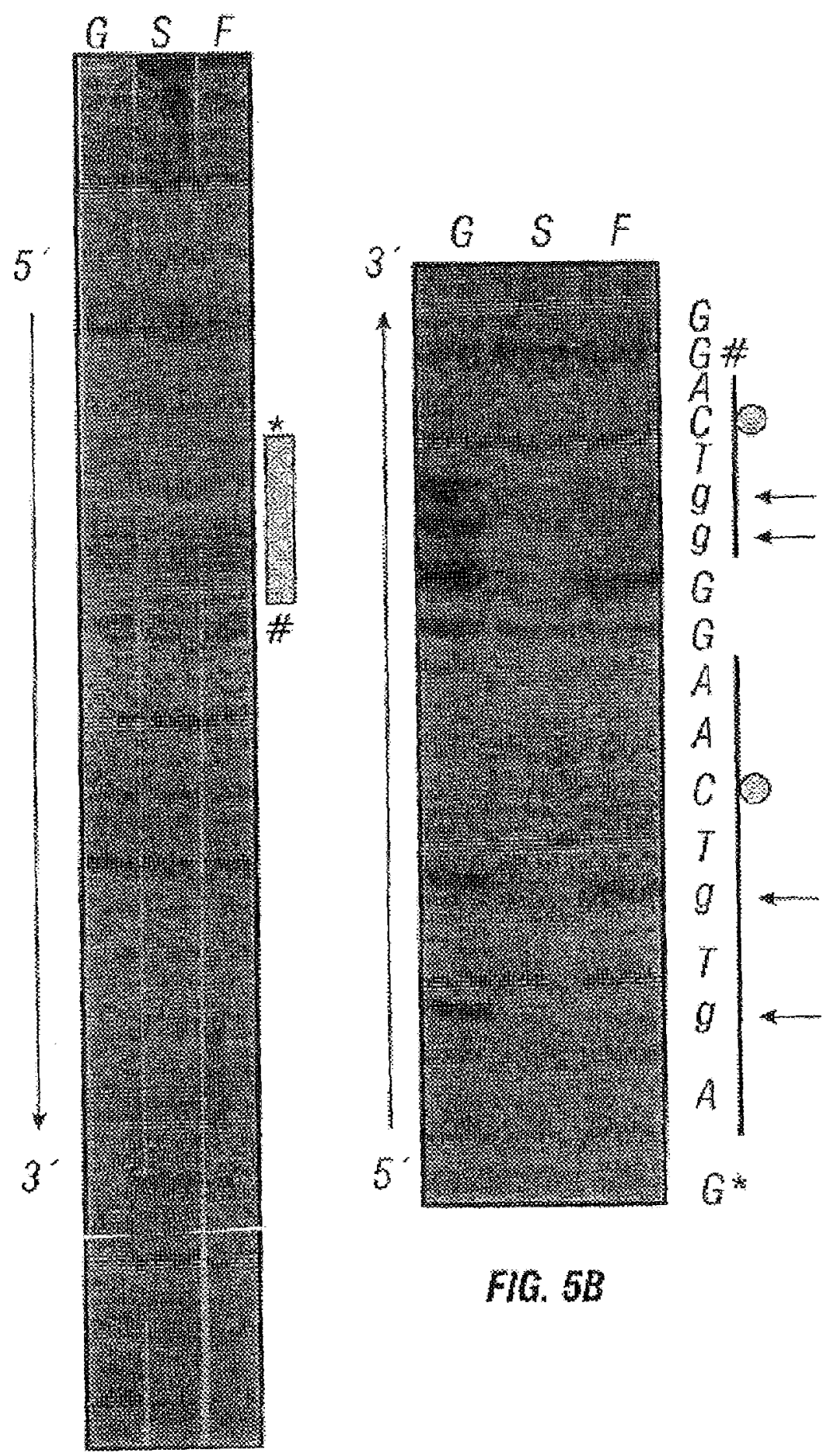

FIG. $5 B$

FIG. 5 A 


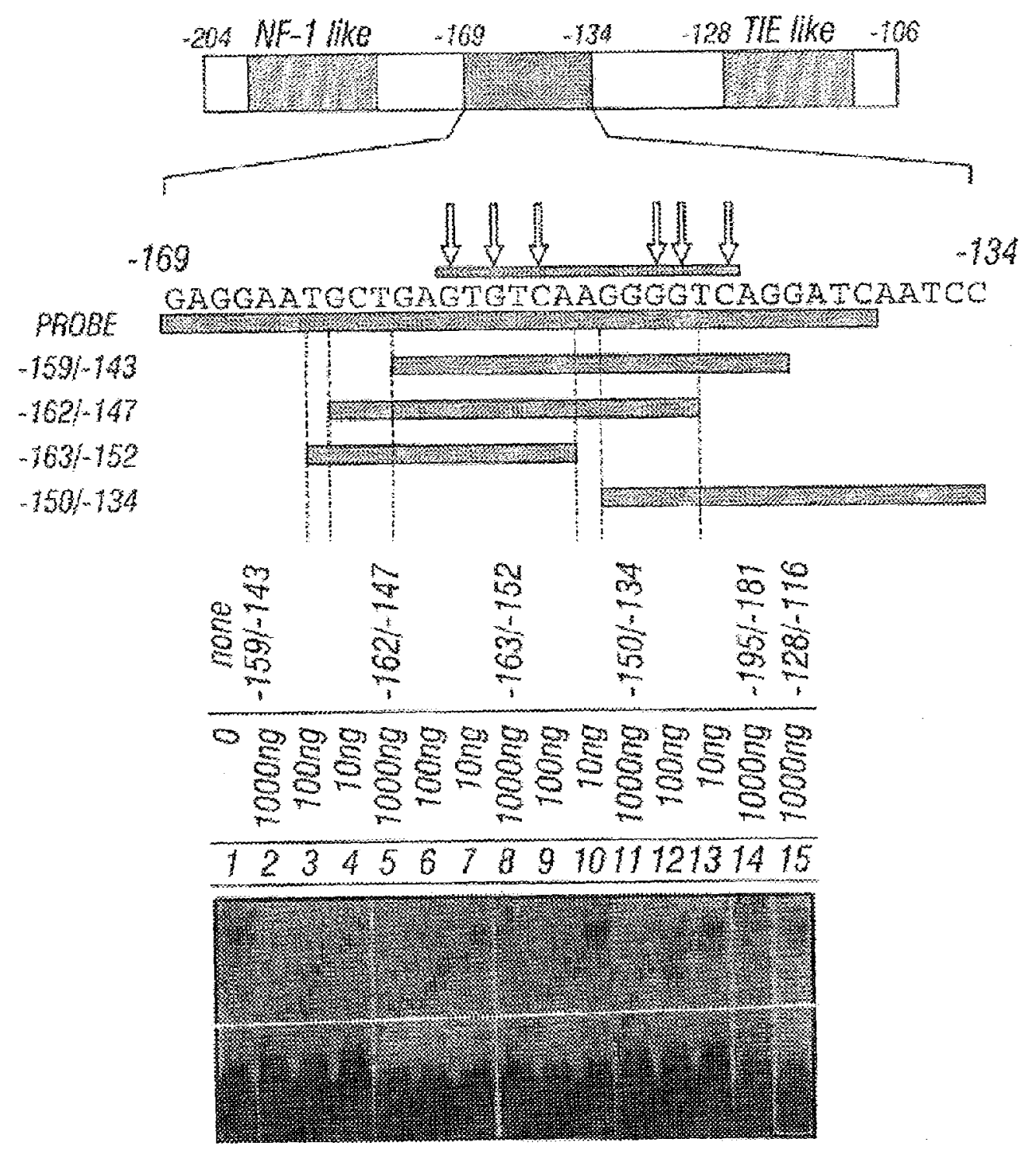

FIO. 6 

U.S. Patent
Jun. 10, 2008
Sheet 11 of 15
US 7,384,634 B2

LUCIFERASE EXPRESSION (Photons $\times 10^{-6}$ )

SEQUENCE USED
\begin{tabular}{|c|c|c|c|}
\hline $\begin{array}{c}\text { NATIVE } \\
\text { GTGTCAAGGGGTC }\end{array}$ & $0.42 \pm 0.01$ & $28.0 \pm 0.9$ & $66.7(100)$ \\
\hline GTGTCAAGGTGTC & $0.41 \pm 0.05$ & $5.7 \pm 0.3$ & $13.9(14)$ \\
\hline GTGTtAAGGGGTC & $0.36 \pm 0.03$ & $13.2 \pm 1.1$ & $36.8(55)$ \\
\hline
\end{tabular}

$* * \star \star * * * *$ BASES MAPPED BY METHYLATION INTERFERENCE

FIG. 7 
U.S. Patent Jun. 10, 2008 Sheet 12 of $15 \quad$ US 7,384,634 B2

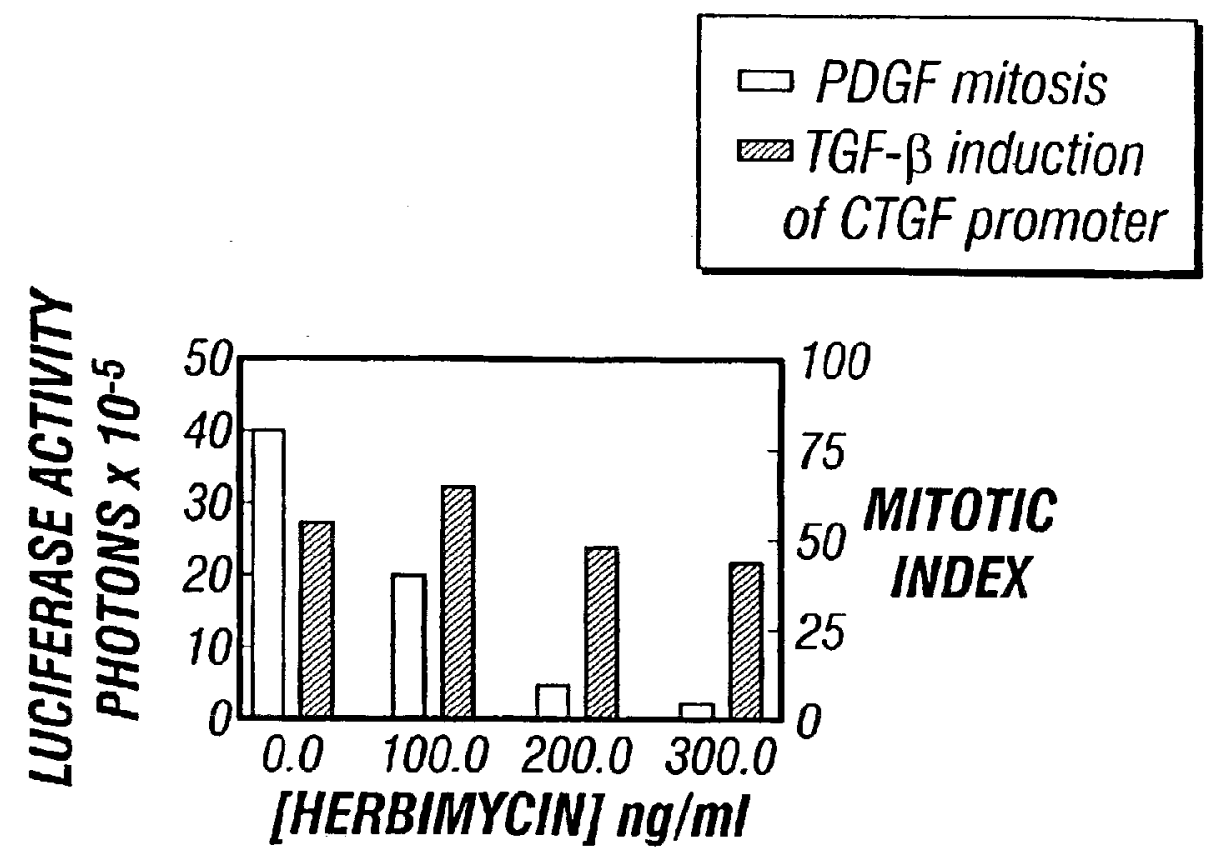

FIG. $8 A$

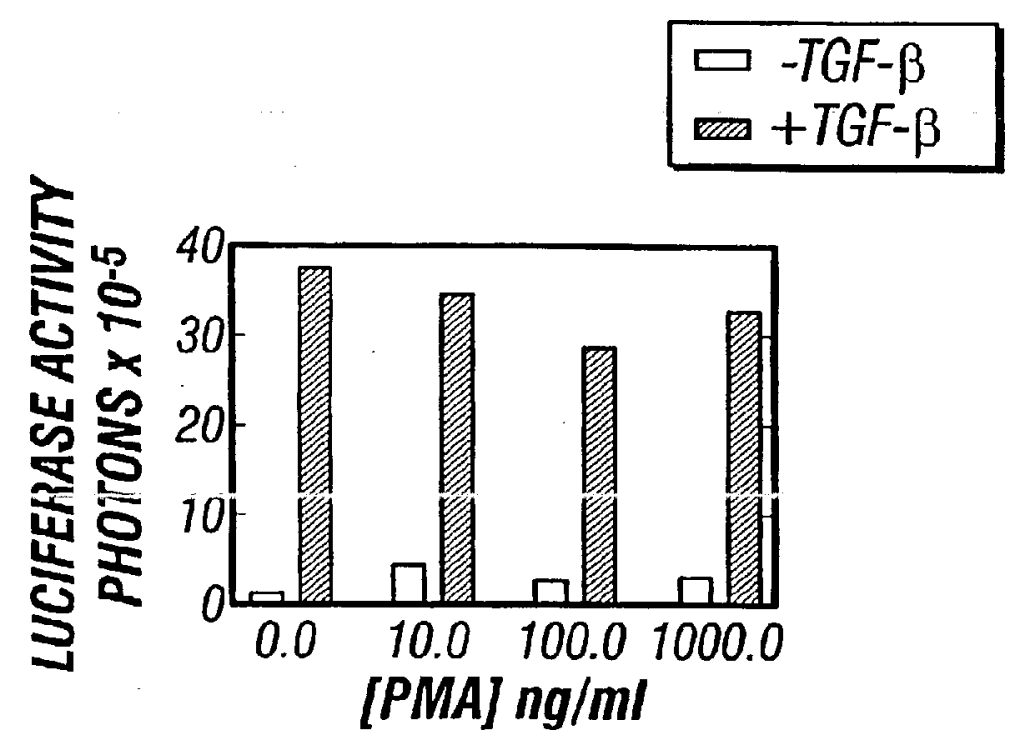

FIG. $8 B$ 


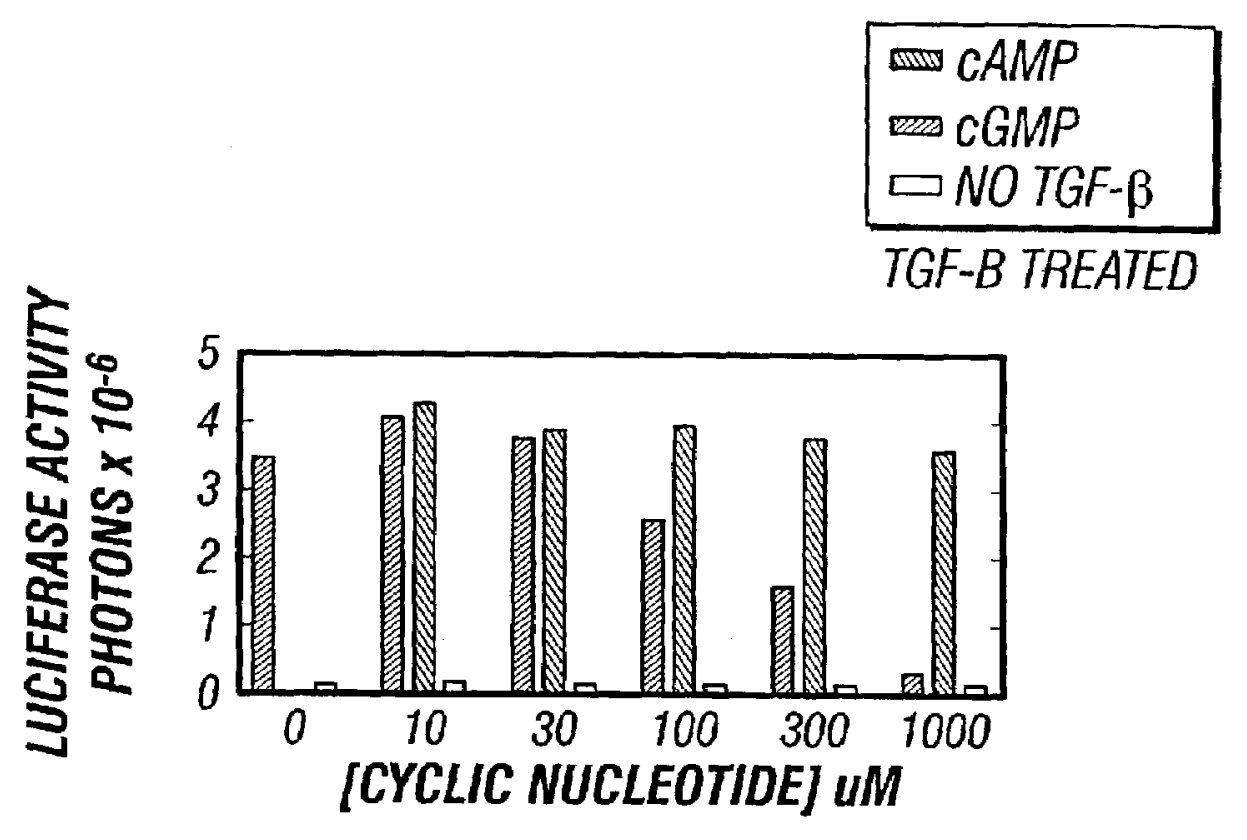

FIG. $8 \mathrm{C}$

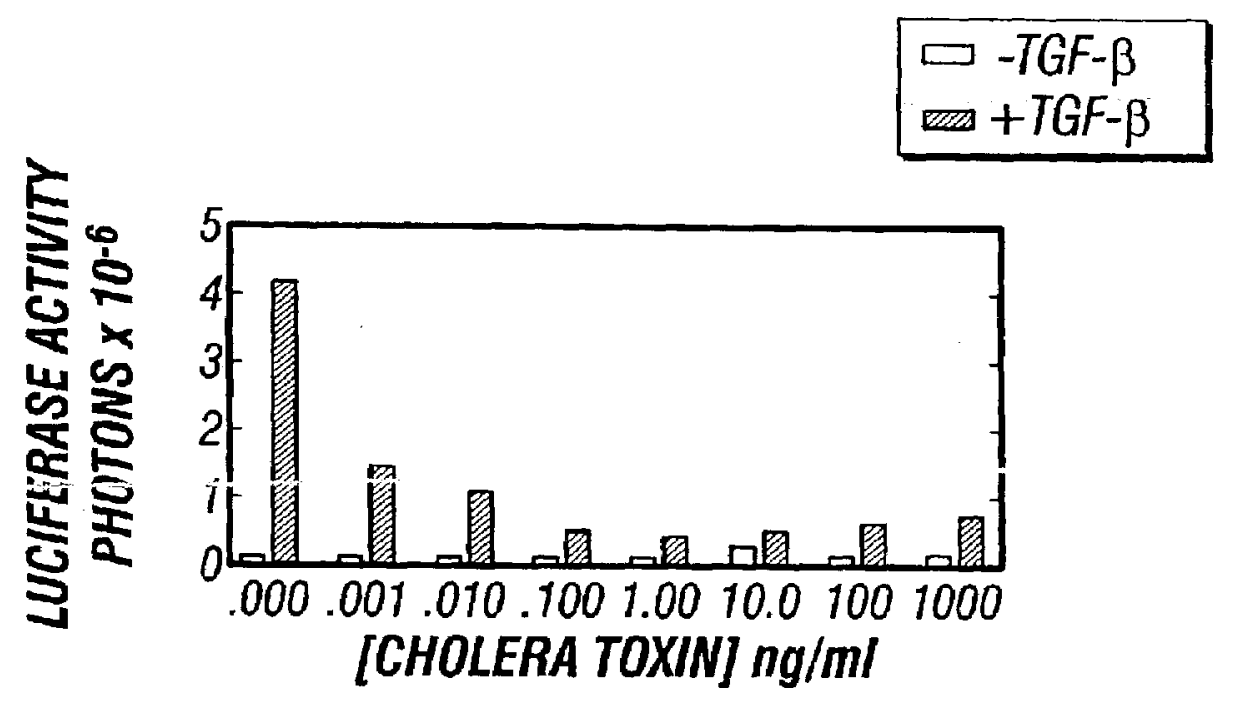

FIG. $8 D$ 


\section{U.S. Patent Jun. 10, $2008 \quad$ Sheet 14 of $15 \quad$ US 7,384,634 B2}

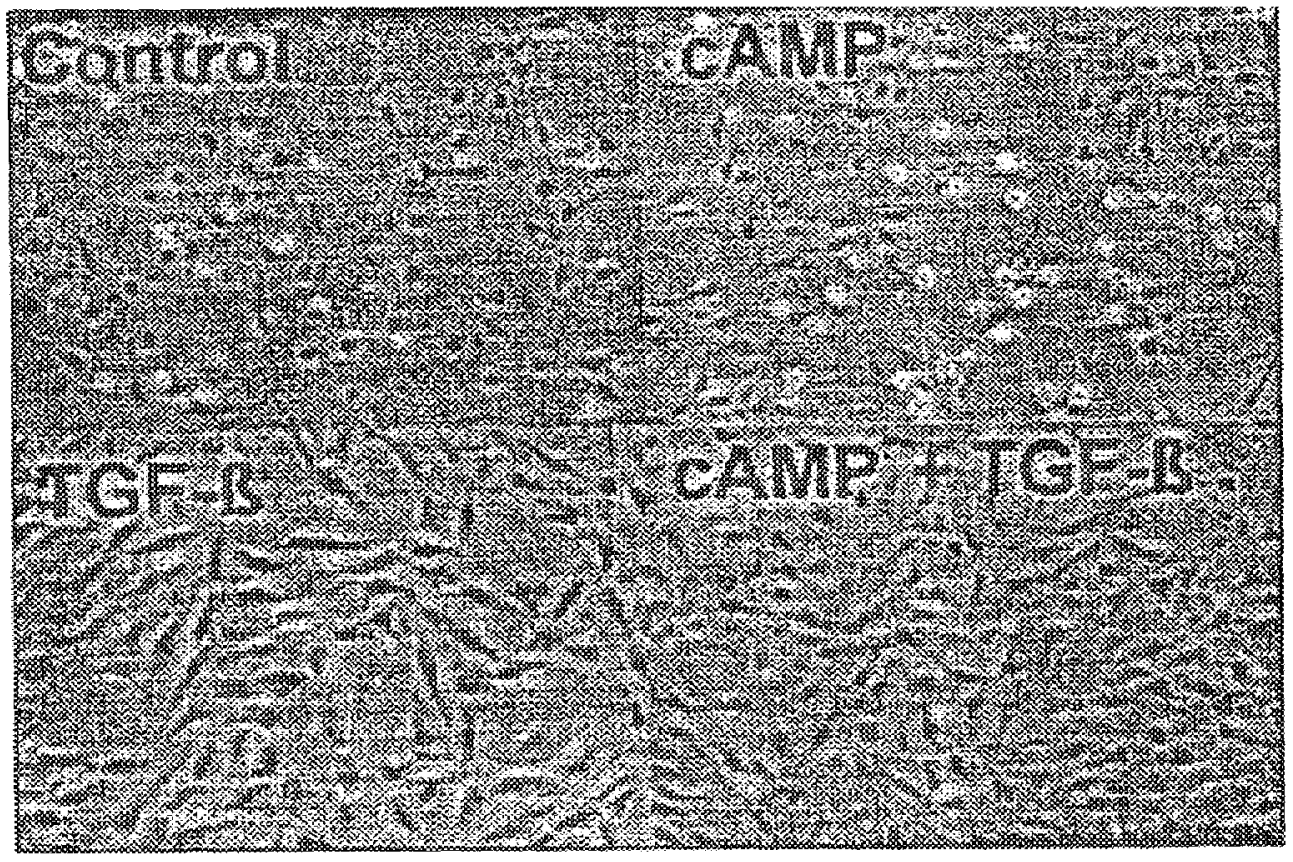

Fro 

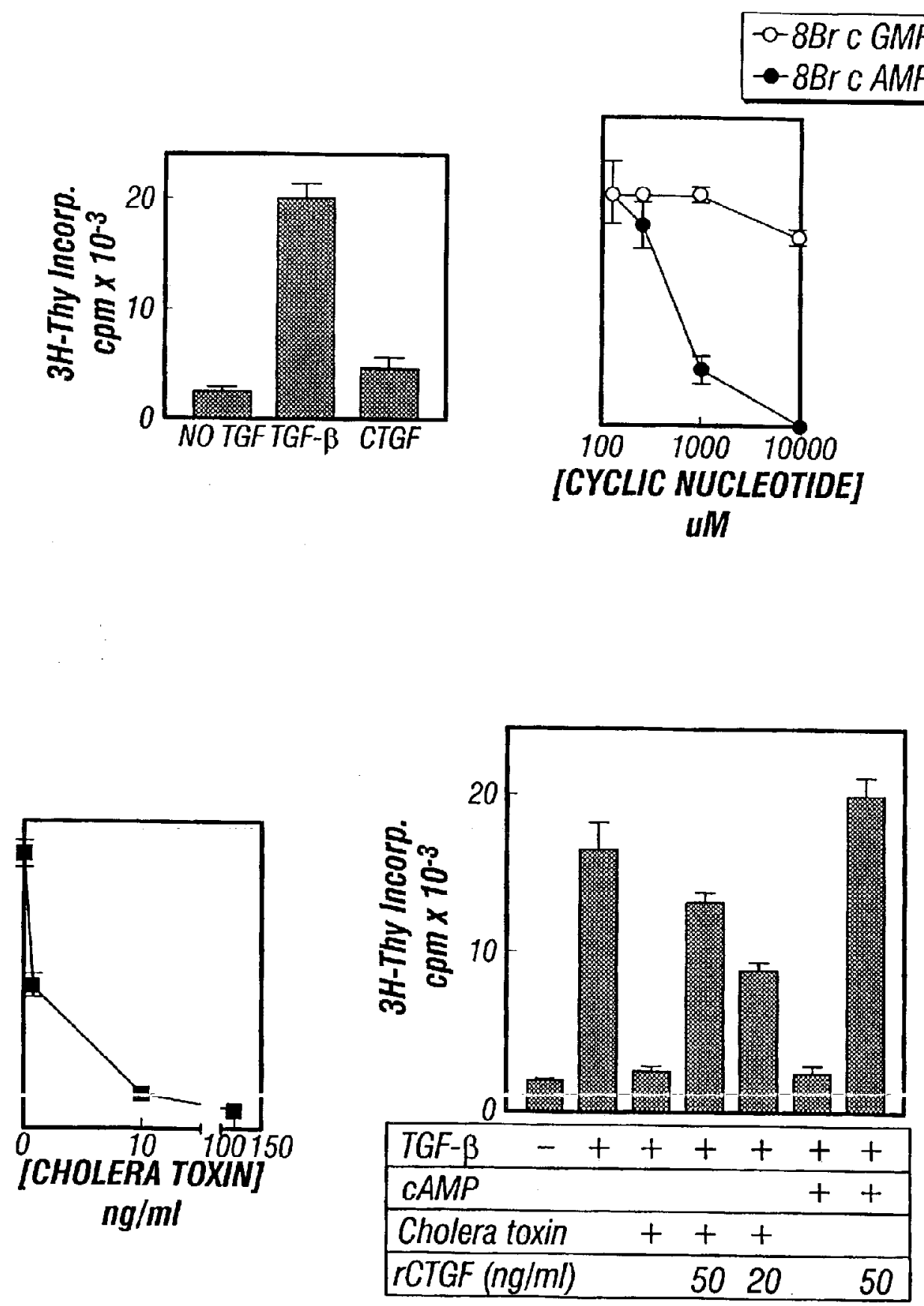

FIG. $8 F$ 
1

\section{CONNECTIVE TISSUE GROWTH FACTOR}

This application is a continuation of prior U.S. application Ser. No. 09/054,363 filed Apr. 2, 1998, now abandoned; which is divisional application of prior U.S. application Ser. No. 08/459,717 filed Jun. 2, 1995, now issued as U.S. Pat. No. $5,770,209$; which is a continuation-in-part application of prior U.S. application Ser. No. 08/386,680 filed Feb. 10, 1995, now issued as U.S. Pat. No. 5,585,270; which is a divisional application of prior U.S. application Ser. No. 08/167,628 filed Dec. 14, 1993, now issued as U.S. Pat. No. $5,408,040$; which is a continuation application of prior U.S. application Ser. No. 07/752,427 filed Aug. 30, 1991, now abandoned. The disclosure of each of the prior applications is considered part of and is incorporated by reference in the 1 disclosure of this application.

This invention was made with Government support from grant no. GM 37223, awarded by the National Institutes of Health. The Government has certain rights in this invention.

\section{BACKGROUND OF THE INVENTION}

1. Field of the Invention

This invention relates generally to the field of growth factors and specifically to Connective Tissue Growth Factor (CTGF). The invention provides novel polynucleotides encoding CTGF, polynucleotides that regulate CTGF expression, diagnostic methods for using CTGF, etc. The invention also provides agents that modulate CTGF and therapeutic methods for using the agents, and assays for identifying additional agents that affect CTGF expression.

2. Related Art

Growth factors are a class of secreted polypeptides that stimulate target cells to proliferate, differentiate and organize in developing tissues. The action of growth factors is dependent on their binding to specific receptors which stimulates a signalling event within the cell. Examples of some wellstudied growth factors include platelet-derived growth factor (PDGF), insulin-like growth factor (IGF-I), transforming growth factor beta (TGF- $\beta$ ), transforming growth factor alpha 40 (TGF- $\alpha$ ), epidermal growth factor (EGF), and fibroblast growth factor (FGF).

PDGF is a cationic, heat-stable protein found in the alphagranules of circulating platelets and is known to be a mitogen and a chemotactic agent for connective tissue cells such as fibroblasts and smooth muscle cells. Because of the activities of this molecule, PDGF is believed to be a major factor involved in the normal healing of wounds and pathologically contributing to such diseases as atherosclerosis and fibrotic diseases. PDGF is a dimeric molecule consisting of an A chain and a $B$ chain. The chains form heterodimers or homodimers and all combinations isolated to date are biologically active.

Studies on the role of various growth factors in tissue regeneration and repair have led to the discovery of PDGFlike proteins. These proteins share both immunological and biological activities with PDGF and can be blocked with antibodies specific to PDGF.

These new growth factors may play a significant role in the normal development, growth, and repair of human tissue. 60 Therapeutic agents derived from these molecules may be useful in augmenting normal or impaired growth processes involving connective tissues in certain clinical states, e.g., wound healing. When these growth factors are involved pathologically in diseases, therapeutic developments from these proteins may be used to control or ameliorate uncontrolled tissue growth.

\section{2}

The formation of new and regenerating tissue requires the coordinate regulation of various genes that produce both regulatory and structural molecules which participate in the process of cell growth and tissue organization. Transforming growth factor beta (TGF- $\beta$ ) appears to be a central regulatory component of this process. TGF- $\beta$ is released by platelets, macrophages and neutrophils which are present in the initial phases of the repair process. TGF- $\beta$ can act as a growth stimulatory factor for mesenchymal cells and as a growth 10 inhibitory factor for endothelial and epithelial cells. The growth stimulatory action of TGF- $\beta$ appears to be mediated via an indirect mechanism involving autocrine growth factors such as PDGF BB or PDGF AA or connective tissue growth factor (CTGF).

Several members of the TGF- $\beta$ superfamily possess activities suggesting possible applications for the treatment of cell proliferative disorders, such as cancer. In particular, TGF- $\beta$ has been shown to be potent growth inhibitor for a variety of cell types (Massague, Cell 49:437, 1987), MIS has been

20 shown to inhibit the growth of human endometrial carcinoma tumors in nude mice (Donahoe et al., Ann Surg 194:472, 1981), and inhibin a has been shown to suppress the development of tumors both in the ovary and in the testis (Matzuk et al., Nature 360:313, 1992).

Many of the members of the TGF- $\beta$ family are also important mediators of tissue repair. TGF- $\beta$ has been shown to have marked effects on the formation of collagen and causes of striking angiogenic response in the newborn mouse (Roberts et al, Proc Natl Acad Sci USA 83:4167, 1986). The bone morphogenic proteins (BMPs) can induce new bone growth and are effective for the treatment of fractures and other skeletal defects (Glowacki et al., Lancet 1:959, 1981; Ferguson et al., Clin Orthoped Relat Res 227:265, 1988; Johnson et al., Clin Orthoped Relat Res 230:257, 1988).

The isolation of growth factors and the genes encoding them is important in the development of diagnostics and therapeutics for various connective tissue-related disorders. The present invention provides such an invention.

\section{SUMMARY OF THE INVENTION}

The present invention provides a novel growth factor, termed Connective Tissue Growth Factor (CTGF). In a first aspect, CTGF is a polypeptide growth factor for connective 45 tissue cells. In one embodiment, the CTGF polypeptide is a mitogenic agent and a chemotactic agent for cells. In another embodiment, CTGF is characterized as a protein (1) existing as a monomer of approximately $36-38 \mathrm{kD}$ molecular weight, and (2) capable of binding to a PDGF receptor. In another embodiment, CTGF comprises the polypeptide of SEQ ID NO:2.

In a second aspect, the present invention provides a polynucleotide encoding a connective tissue growth factor. In one particular embodiment, the polynucleotide comprises the 55 sequence of SEQ ID NO:1.

In a further aspect, the invention provides a method for accelerating wound healing in a subject by applying to the wound an effective amount of a composition which contains CTGF.

In yet another aspect, the invention provides a method of diagnosing pathological states in a subject suspected of having pathology characterized by a cell proliferative disorder which comprises, (1) obtaining a sample suspected of containing CTGF from the subject, (2) determining the level of CTGF in the sample, and (3) comparing the level of CTGF in the sample to the level of CTGF in normal tissues. In one embodiment, the pathology is selected from the group con- 
3

sisting of pulmonary fibrosis, kidney fibrosis, tumor formation and growth, and glaucoma.

In still another aspect, a method of ameliorating diseases characterized by a cell proliferative disorder, by treating the site of the disease with an effective amount of a CTGF reactive agent is also provided.

The present invention identifies polynucleotides that regulate expression of CTGF. In one aspect, the polynucleotides comprise a consensus sequence representing the CTGF promoter from residue -210 to +17 (SEQ ID NO:8). In particular exemplary embodiments, the polynucleotides comprise a sequence selected from SEQ ID NO:6 or 7. In additional embodiments, the polynucleotides comprise at least one sequence selected from the group consisting of SEQ ID NO:9-12.

In another aspect, the polynucleotide is a TGF- $\beta$ responsive or regulatory element (T $\beta R E)$ in the $5^{\prime}$ untranslated nucleotides of the CTGF gene (about -154 to -145 ). In one particular embodiment, the TGF- $\beta$ responsive element comprises SEQ ID NO:11.

Based on the identification of the polynucleotide regulatory elements, the invention provides a method for identifying an agent which affects CTGF expression comprising incubating the agent with a host cell transfected with a reporter construct comprising at least one regulatory element operably linked to a polynucleotide encoding a reporter protein, and measuring the effect of the agent on reporter protein expression. In one embodiment, the regulatory element comprises the sequence of SEQ ID NO:8. In another embodiment, the regulatory element comprises a sequence selected from SEQ ID NO:6 or SEQ ID NO:7. In yet another embodiment, the regulatory element comprises at least one sequence selected from the group consisting of SEQ ID NO:9-12. Thus, the invention provides a means for drug discovery for treatment of cell proliferative disorders associated with CTGF including, e.g., pulmonary fibrosis, kidney fibrosis, tumor formation and growth, and glaucoma.

\section{BRIEF DESCRIPTION OF THE DRAWINGS}

FIG. 1A shows the structural organization of the CTGF gene. Exons are indicated by boxed regions, with solid areas in the gene corresponding to the open reading frame.

FIG. 1B shows a comparison of nucleotide sequences between CTGF promoter (SEQ ID NO:6) and fisp-12 promoter (SEQ ID NO:7). Identical nucleotides are marked with asterisks. The TATA box and other consensus sequences are indicated and shaded. The site of transcriptional initiation is indicated at position number +1 .

FIG. 1C shows the complete nucleotide and deduced amino acid sequence (SEQ ID NOS 1 and 2) for the CTGF structural gene and $5^{\prime}$ and 3 'untranslated sequences.

FIGS. 2A-C show a Northern blot analysis. Panel (A) shows prolonged induction of CTGF mRNA by short term TGF- $\beta$. Confluent cultures of human skin fibroblasts were incubated with DMEM-ITS containing $5 \mu \mathrm{g} / \mathrm{ml}$ of Insulin, 5 $\mu \mathrm{g} / \mathrm{ml}$ of Transferrin and $5 \mathrm{ng} / \mathrm{ml}$ of Selenium for 24 hours prior to the addition of TGF- $\beta$. After the treatment with 10 $\mathrm{ng} / \mathrm{ml}$ of TGF- $\beta$ for 1 hour, cells were washed with PBS and incubated with DMEM-ITS for indicated time periods. Panel (B) shows the effect of cycloheximide (CHX) on induction of CTGF mRNA. Lane A and $\mathrm{H}$ are non-treated control cells at 4 hours and 24 hours, respectively. Lane B, 4 hrs. Cycloheximide $(10 \mu \mathrm{g} / \mathrm{ml})$; Lane C, $4 \mathrm{hrs}$ TGF- $\beta$ present for 1 hour during hour 1 of 2 of cycloheximide exposure; Lane E, same as B with RNA prepared 24 hours after addition of cycloheximide; Lane f, 24 hours TGF- $\beta(10 \mu \mathrm{g} / \mathrm{ml})$; Lane G, same as D

\section{4}

with RNA prepared 24 hours after addition of cycloheximide and 22 hours after removal of TGF- $\beta$. Panel (C) shows the effect of protein synthesis inhibitors on induction of CTGF mRNA. Cells were treated with puromycin or anisomycin for 4 hours. TGF- $\beta$ was added 1 hour after the addition of protein synthesis inhibitor and cells were incubated for 3 hours prior to isolation of total RNA. CTGF transcripts were analyzed by Northern blot as described in the EXAMPLES.

FIG. 3A shows deletion analysis of CTGF promoter-lu10 ciferase constructs. Known consensus sequences are indicated. NIH/3T3 fibroblasts were transfected with the constructs and $10 \mathrm{ng} / \mathrm{ml}$ of TGF- $\beta$ was added for activation of the cells and cell extracts were prepared 24 hours later. Relative induction is indicated as fold above non-induced control cells

15 and normalized using the $\beta$-galactosidase activity from control plasmids that were cotransfected with the CTGF constructs. These studies were repeated 6 times with similar results. Data represent the average of duplicate transfections with the indicated construct performed in a single set of 20 experiments.

FIG. 3B shows TGF- $\beta$ response of an SV40 enhancerless promoter element-luciferase reporter construct containing the TGF- $\beta$ region of the CTGF promoter. The indicated regions of the CTGF promoter were cloned in both orientations upstream from an SV40 enhancerless promoter. Cells were treated with $10 \mathrm{ng} / \mathrm{ml}$ of TGF- $\beta$ for $24 \mathrm{hrs}$ prior to assay for luciferase activity. These experiments were repeated 4 times with similar results. Data represents the average of duplicate transfections of the indicated construct from a single experimental set.

FIG. 4 shows competitive gel shift assays to delineate $\mathrm{TGF}-\beta$ response element (T $\beta \mathrm{RE}$ ) in the -205 to -109 region of the CTGF promoter. A nucleotide fragment consisting of the region from -205 to -109 of the CTGF promoter was end 35 labeled with $[32 \mathrm{P}]$ and used in competitive gel shifts with the indicated oligonucleotides. The specific gel shifted band is indicated by the arrow. A diagram of the sequences used indicates the position of these corresponding to the NF-1 and TIE like elements. The numbered fragments in the diagram 40 indicate the lane number in the competitive gel shift assay with the specific nucleotide sequence indicated above the lane (i.e. $3,-205 /-150$ ). Unlabeled competitors were used at a 250 fold molar excess over the labeled fragment. Only oligonucleotides containing the region from -169 to -150 acted as 45 specific competitors. Neither the NF-1 (SEQ ID NO:9) or TIE-like (SEQ ID NO:10) regions competed in this assay.

FIGS. 5A and $\mathrm{B}$ show a methylation interference assay of the -205 to -109 region of the CTGF promoter. FIG. 5A shows a sequence analysis of the region from -205 to -109 . Sequence from -200 to -113 is shown. Lane $G$ is the $G$ sequence of the intact labeled probe, Lane $S$ is the sequence of the shifted band and Lane $F$ is the sequence of the non-shifted free probe from the same sample. The only region containing mission $\mathrm{G}$ residues is from positions -157 to -145 (SEQ ID NO:11).

FIG. 5B shows a sequence analysis of the region -159 to -142 using a smaller fragment of the promoter (-169 to 193). Lanes are the same as in $A$. Competed $G$ residues in this sequence are indicated by arrows. Solid circles indicate $G$ 60 residues detected in analysis of complementary strand (data not shown). Symbols * and \# are for orientation with sequence in $\mathrm{A}$.

FIG. 6 shows competitive gel shift titration assay of oligonucleotides in the T $\beta R E$. Overlapping and non-overlapping oligonucleotides containing portions of the -159 to -143 region of the CTGF promoter were tested in the competitive gel shift assay using a $\left[{ }^{32} \mathrm{P}\right]$-end labeled human CTGF pro- 


\section{US 7,384,634 B2}

5

moter fragment $(-205$ to -109$)$. The intact fragment $(-159$ to -143) exhibits the highest affinity with complete competition at $10 \mathrm{ng}$. All other fragments, which contain only a portion of this sequence, are less effective with the -150 to -134 region being the least effective. Lanes $\mathbf{1 4}$ and 15 are the NF-1 and TIE like elements respectively and show no competition at 5000-fold molar excess of labeled probe.

FIG. 7 shows point mutations in the T $\beta$ RE decreases induction of the CTGF promoter by TGF- $\beta$ (SED ID NOS 11,15 and 16).

FIGS. 8A-D show the effect of herbimycin $(8 \mathrm{~A})$, phorbol ester (8B), cAMP (8C), and cholera toxin (8D) on TGF- $\beta$ induced CTGF expression as measured in a luciferase assay.

FIG. 8E shows photomicrographs of NIH/3T3 cells either untreated, treated with TGF- $\beta$, cAMP ( 8 bromo cyclic adenosine monophosphate; $8 \mathrm{Br}$ cAMP), or cAMP and TGF$\beta$.

FIG. 8 F shows the results of inhibition of anchorage independent growth by $8 \mathrm{Br} \mathrm{cAMP}$ and cholera toxin, and reversal of cAMP or cholera toxin inhibition of TGF- $\beta$ induced anchorage independent growth by CTGF.

\section{DETAILED DESCRIPTION OF THE INVENTION}

The present invention discloses a novel protein growth factor called Connective Tissue Growth Factor (CTGF). This protein may play a significant role in the normal development, growth and repair of human tissue. The discovery of the CTGF protein and cloning of the cDNA encoding this molecule is significant in that it is a previously unknown growth factor having mitogenic and chemotactic activities for connective tissue cells. The biological activity of CTGF is similar to that of PDGF, however, CTGF is the product of a gene unrelated to the A or B chain genes of PDGF. Since CTGF is produced by endothelial and fibroblastic cells, both of which are present at the site of a wound, it is probable that CTGF functions as a growth factor in wound healing.

Pathologically, CTGF may be involved in diseases in which there is an overgrowth of connective tissue cells, such as cancer, tumor formation and growth, fibrotic diseases (e.g., pulmonary fibrosis, kidney fibrosis, glaucoma) and atherosclerosis. The CTGF polypeptide is useful as a therapeutic in cases in which there is impaired healing of skin wounds or there is a need to augment the normal healing mechanisms. Additionally, antibodies to CTGF polypeptide or fragments could be valuable as diagnostic tools to aid in the detection of diseases in which CTGF is a pathological factor. Therapeutically, antibodies or fragments of the antibody molecule could also be used to neutralize the biological activity of CTGF in diseases where CTGF is inducing the overgrowth of tissue.

The primary biological activity of CTGF polypeptide is its mitogenicity, or ability to stimulate target cells to proliferate. The ultimate result of this mitogenic activity in vivo, is the growth of targeted tissue. CTGF also possesses chemotactic activity, which is the chemically induced movement of cells as a result of interaction with particular molecules. Preferably, the CTGF of this invention is mitogenic and chemotactic for connective tissue cells, however, other cell types may be responsive to CTGF polypeptide as well.

The CTGF polypeptide of the invention is characterized by existing as a monomer of approximately $36-38 \mathrm{kD}$ molecular weight. CTGF is secreted by cells and is active upon interaction with a receptor on a responsive cell. CTGF is antigenically related to PDGF although there is little if any peptide sequence homology. Anti-PDGF antibody has high affinity to the non-reduced forms of the PDGF isomers and the CTGF molecule and ten-fold less affinity to the reduced forms of

\section{6}

these peptides, which lack biological activity. This suggests that there are regions of shared tertiary structure between the PDGF isomers and the CTGF molecule, resulting in common antigenic epitopes.

The term "substantially pure" as used herein refers to CTGF which is substantially free of other proteins, lipids, carbohydrates or other materials with which it is naturally associated. The substantially pure polypeptide will yield a single major band on a non-reducing polyacrylamide gel. The 10 purity of the CTGF polypeptide can also be determined by amino-terminal amino acid sequence analysis. CTGF polypeptide includes functional fragments of the polypeptide, so long as the mitogenic and chemotactic activities of CTGF are retained. Smaller peptides containing the biologi15 cal activity of CTGF are included in the invention. Additionally, more effective CTGF molecules produced, for example, through site directed mutagenesis of the CTGF cDNA are included.

The invention provides an isolated polynucleotide encod20 ing the CTGF protein. The term "isolated" as used herein refers to a polynucleotide which is substantially free of other polynucleotides, proteins, lipids, carbohydrates or other materials with which it is naturally associated. These polynucleotides include DNA, cDNA and RNA sequences which encode connective tissue growth factor. It is understood that all polynucleotides encoding all or a portion of CTGF are also included herein, so long as they encode a polypeptide with the mitogenic and chemotactic activity of CTGF. Such polynucleotides include naturally occurring forms, such as allelic variants, and intentionally manipulated forms, for example, mutagenized polynucleotides, as well as artificially synthesized polynucleotides. For example, CTGF polynucleotide may be subjected to site-directed mutagenesis. The polynucleotides of the invention include sequences that are degen5 erate as a result of the genetic code. There are only 20 natural amino acids, most of which are specified by more than one codon. Therefore as long as the amino acid sequence of CTGF is functionally unchanged, all degenerate nucleotide sequences are included in the invention.

The term "polynucleotide" also denotes DNA, cDNA and RNA which encode untranslated sequences which flank the structural gene encoding CTGF. For example, a polynucleotide of the invention includes $5^{\prime}$ regulatory nucleotide sequences and $3^{\prime}$ untranslated sequences associated with the 45 CTGF structural gene. The polynucleotide of the invention which includes the $5^{\prime}$ and $3^{\prime}$ untranslated region is illustrated in FIG. 1C. The $5^{\prime}$ regulatory region, including the promoter, is illustrated in FIG. 1B (SEQ ID NO:6, CTGF; and SEQ ID) NO:7; fisp-12).

50 The sequence of the cDNA for CTGF contains an open reading frame of 1047 nucleotides with an initiation site at position 130 and a TGA termination site at position 1177 and encodes a peptide of 349 amino acids. There is only a $40 \%$ sequence homology between the CTGF eDNA and the 55 CDNA for both the A and B chains of PDGF.

The present invention provides CTGF promoter nucleotides -823 to +74 as well as a TGF- $\beta$ regulatory element (T $\beta R E$ ) located between positions -162 and -128 of the CTGF promoter sequence. Methylation interference and 60 competition gel shift assays map a unique 13-nucleotide sequence between positions -157 and -145 delineating a novel TGF- $\beta$ cis-regulatory element (SEQ ID NO:11).

The CTGF open reading frame encodes a polypeptide which contains 39 cysteine residues, indicating a protein with multiple intramolecular disulfide bonds. The amino terminus of the peptide contains a hydrophobic signal sequence indicative of a secreted protein and there are two N-linked glyco- 
7

sylation sites at asparagine residues 28 and 225 in the amino acid sequence. CTGF is a member of a protein family that includes serum induced immediate early gene products such as Cyr61 (O'Brien et al., Mol Cell Biol 10:3569, 1990) and Fisp12 (Ryseck et a1., Cell Growth Diff 2:225, 1991)/BigM2 (Brunner et al., DNA Cell Biol 10:293, 1991); a v-src induced peptide (CEF-10)(Simmons et al., Proc Nati Acad Sci USA $86: 1178,1989)$ and aputative oncoprotein (nov)(Joliot etal., Mol Cell Biol 12:10, 1992). Twisted gastrulation (tsg), a gene that functions to control the induction of medial mesodermal elements in the dorsal/ventral patterning of Drosophila embryogenesis is more distantly related to CTGF (Mason et al., Genes Devel 8:1489, 1994). There is a $45 \%$ overall sequence homology between the CTGF polypeptide and the polypeptide encoded by the CEF-10 mRNA transcript (Simmons et al, Proc Natl Acad Sci USA 86:1178, 1989); the homology reaches $52 \%$ when a putative alternative splicing region is deleted.

DNA sequences of the invention can be obtained by several methods. For example, the DNA can be isolated using hybridization procedures which are well known in the art. These include, but are not limited to: 1) hybridization of probes to genomic or cDNA libraries to detect shared nucleotide sequences and 2) antibody screening of expression libraries to detect shared structural features.

Screening procedures which rely on nucleic acid hybridization make it possible to isolate any gene sequence from any organism, provided the appropriate probe is available. For example, oligonucleotide probes, which correspond to a part of the sequence encoding the protein in question, can be synthesized chemically. This requires that short, oligopeptide, stretches of amino acid sequence must be known. The DNA sequence encoding the protein can be deduced from the genetic code, however, the degeneracy of the code must be taken into account. It is possible to perform a mixed addition reaction when the sequence is degenerate. This includes a heterogeneous mixture of denatured double-stranded DNA. For such screening, hybridization is preferably performed on either single-stranded DNA or denatured double-stranded DNA. Hybridization is particularly useful in the detection of 40 cDNA clones derived from sources where an extremely low amount of mRNA sequences relating to the polypeptide of interest are present. In other words, by using stringent hybridization conditions directed to avoid non-specific binding, it is possible, for example, to allow the autoradiographic visualization of a specific CDNA clone by the hybridization of the target DNA to that single probe in the mixture which is its complete complement (Wallace et al., Nucleic Acid Res 9:879, 1981).

A cDNA expression library, such as lambda gt11, can be screened indirectly for CTGF peptides having at least one epitope, using antibodies specific for CTGF or antibodies to PDGF which cross react with CTGF. Such antibodies can be either polyclonally or monoclonally derived and used to detect expression product indicative of the presence of CTGF cDNA.

DNA sequences encoding CTGF can be expressed in vitro by DNA transfer into a suitable host cell. "Host cells" are cells in which a vector can be propagated and its DNA expressed. The term also includes any progeny of the subject host cell. It is understood that all progeny may not be identical to the parental cell since there may be mutations that occur during replication. However, such progeny are included when the term "host cell" is used.

DNA sequences encoding CTGF can be expressed in vivo 65 in either prokaryotes or eukaryotes. Methods of expressing DNA sequences having eukaryotic coding sequences in

\section{8}

prokaryotes are well known in the art. Hosts include microbial, yeast and mammalian organisms.

Biologically functional viral and plasmid DNA vectors capable of expression and replication in a host are known in the art. Such vectors are used to incorporate DNA sequences of the invention. In general, expression vectors containing promotor sequences which facilitate the efficient transcription of the inserted eukaryotic genetic sequence are used in connection with the host. The expression vector typically 10 contains an origin of replication, a promoter, and a terminator, as well as specific genes which are capable of providing phenotypic selection of the transformed cells.

In addition to expression vectors known in the art such as bacterial, yeast and mammalian expression systems, bacu5 lovirus vectors may also be used. One advantage to expression of foreign genes in this invertebrate virus expression vector is that it is capable of expression of high levels of recombinant proteins, which are antigenically and functionally similar to their natural counterparts. Baculovirus vectors 20 and the appropriate insect host cells used in conjunction with the vectors will be known to those skilled in the art.

The term "recombinant expression vector" refers to a plasmid, virus or other vehicle known in the art that has been manipulated by insertion or incorporation of the CTGF 25 genetic sequences. Such expression vectors contain a promoter sequence which facilitates the efficient transcription of the inserted genetic sequence of the host. The expression vector typically contains an origin of replication, a promoter, as well as specific genes which allow phenotypic selection of 30 the transformed cells. Vectors suitable for use in the present invention include, but are not limited to the T7-based expression vector for expression in bacteria (Rosenberg et al., Gene 56:125, 1987), the pMSXND expression vector for expression in mammalian cells (Lee and Nathans, J Biol Chem 5 263:3521, 1988) and baculovirus-derived vectors for expression in insect cells. The DNA segment can be present in the vector operably linked to regulatory elements, for example, a promoter (e.g., T7, metallothionein I, or polyhedrin promoters).

The vector may include a phenotypically selectable marker to identify host cells which contain the expression vector. Examples of markers typically used in prokaryotic expression vectors include antibiotic resistance genes for ampicillin $(\beta$-lactamases), tetracycline and chloramphenicol (chloram45 phenicol acetyltransferase). Examples of such markers typically used in mammalian expression vectors include the gene for adenosine deaminase (ADA), aminoglycoside phosphotransferase (neo, G418), dihydrofolate reductase (DHFR), hygromycin-B-phosphotransferase (HPH), thymidine kinase

50 (TK), and xanthine guanine phosphoribosyltransferse (XGPRT, gpt).

The isolation and purification of host cell expressed polypeptides of the invention may be by any conventional means such as, for example, preparative chromatographic 55 separations and immunological separations such as those involving the use of monoclonal or polyclonal antibody.

Transformation of the host cell with the recombinant DNA may be carried out by conventional techniques well known to those skilled in the art. Where the host is prokaryotic, such as 60 E. coli, competent cells which are capable of DNA uptake can be prepared from cells harvested after exponential growth and subsequently treated by the $\mathrm{CaCl}_{2}$ method using procedures well known in the art. Alternatively, $\mathrm{MgCl}_{2}$ or $\mathrm{RbCl}$ could be used.

Where the host used is a eukaryote, various methods of DNA transfer can be used. These include transfection of DNA by calcium phosphate-precipitates, conventional mechanical 
9

procedures such as microinjection, insertion of a plasmid encased in liposomes, or the use of virus vectors. Eukaryotic cells can also be cotransformed with DNA sequences encoding the polypeptides of the invention, and a second foreign DNA molecule encoding a selectable phenotype, such as the herpes simplex thymidine kinase gene. Another method is to use a eukaryotic viral vector, such as simian virus 40 (SV40) or bovine papilloma virus, to transiently infect or transform eukaryotic cells and express the protein. (Eukaryotic Viral Vectors, Cold Spring Harbor Laboratory, Gluzman ed., 1982). Examples of mammalian host cells include COS, BHK, 293, and CHO cells.

Eukaryotic host cells may also include yeast. For example, DNA can be expressed in yeast by inserting the DNA into appropriate expression vectors and introducing the product into the host cells. Various shuttle vectors for the expression of foreign genes in yeast have been reported (Heinemann et al., Nature 340:205, 1989; Rose et al., Gene 60:237, 1987).

The invention provides antibodies which are specifically reactive with CTGF polypeptide or fragments thereof. Although this polypeptide is cross reactive with antibodies to PDGF, not all antibodies to CTGF will also be reactive with PDGF. Antibody which consists essentially of pooled monoclonal antibodies with different epitopic specificities, as well as distinct monoclonal antibody preparations are provided. Monoclonal antibodies are made from antigen containing fragments of the protein by methods well known in the art (Kohler et al., Nature 256:495, 1975; Current Protocols in Molecular Biology, Ausubel et al., ed., John Wiley \& Sons, New York, 1989). Monoclonal antibodies specific for CTGF can be selected, for example, by screening for hybridoma culture supernatants which react with CTGF, but do not react with PDGF.

Antibody which consists essentially of pooled monoclonal antibodies with different epitopic specificities, as well as distinct monoclonal antibody preparations are provided. Monoclonal antibodies are made from antigen containing fragments of the protein by methods well known in the art (Kohler et al, Nature 256:495, 1975; Ausubel, supra).

The term "antibody" as used in this invention includes intact molecules as well as fragments thereof, such as Fab, $\mathrm{F}(\mathrm{ab})_{2}$, and $\mathrm{Fv}$ which are capable of binding the epitopic determinant. These antibody fragments retain some ability to selectively bind with its antigen or receptor and are defined as follows:

(1) Fab, the fragment which contains a monovalent antigenbinding fragment of an antibody molecule can be produced by digestion of whole antibody with the enzyme papain to yield an intact light chain and a portion of one heavy chain;

(2) Fab', the fragment of an antibody molecule can be obtained by treating whole antibody with pepsin, followed by reduction, to yield an intact light chain and a portion of the heavy chain; two Fab' fragments are obtained per antibody molecule;

(3) $\left(\mathrm{Fab}^{\prime}\right)_{2}$, the fragment of the antibody that can be obtained by treating whole antibody with the enzyme pepsin without subsequent reduction; $F\left(a b^{\prime}\right)_{2}$ is a dimer of two Fab' fragments held together by two disulfide bonds;

(4) Fv, defined as a genetically engineered fragment containing the variable region of the light chain and the variable region of the heavy chain expressed as two chains; and

(5) Single chain antibody ("SCA"), defined as a genetically engineered molecule containing the variable region of the light chain, the variable region of the heavy chain, linked 65 by a suitable polypeptide linker as a genetically fused single chain molecule.
10

Methods of making these fragments are known in the art. (See for example, Harlow and Lane, Antibodies: A Laboratory Manual, Cold Spring Harbor Laboratory, New York (1988), incorporated herein by reference).

As used in this invention, the term "epitope" means any antigenic determinant on an antigen to which the paratope of an antibody binds. Epitopic determinants usually consist of chemically active surface groupings of molecules such as amino acids or sugar side chains and usually have specific 10 three dimensional structural characteristics, as well as specific charge characteristics.

Antibodies which bind to CTGF polypeptide of the invention can be prepared using an intact polypeptide or fragments containing small peptides of interest as the immunizing antigen. The polypeptide or a peptide used to immunize an animal can be derived from translated CDNA or chemical synthesis which can be conjugated to a carrier protein, if desired. Such commonly used carriers which are chemically coupled to the peptide include keyhole limpet hemocyanin (KLH), thyro20 globulin, bovine serum albumin (BSA), and tetanus toxoid. The coupled peptide is then used to immunize the animal (e.g., a mouse, a rat, or a rabbit).

If desired, polyclonal or monoclonal antibodies can be further purified, for example, by binding to and elution from 25 a matrix to which the polypeptide or a peptide to which the antibodies were raised is bound. Those of skill in the art will know of various techniques common in the immunology arts for purification and/or concentration of polyclonal antibodies, as well as monoclonal antibodies (See for example, Coli30 gan et al., Unit 9, Current Protocols in Immunology, Wiley Interscience, 1994, incorporated herein by reference).

It is also possible to use the anti-idiotype technology to produce monoclonal antibodies which mimic an epitope. For example, an anti-idiotypic monoclonal antibody made to a first monoclonal antibody will have a binding domain in the hypervariable region which is the "image" of the epitope bound by the first monoclonal antibody.

The invention provides a method for accelerating wound healing in a subject, e.g., a human, by applying to the wound 40 an effective amount of a composition which contains CTGF, preferably purified. PDGF and PDGF-related molecules, such as CTGF, are involved in normal healing of skin wounds. The CTGF polypeptide of this invention is valuable as a therapeutic in cases in which there is impaired healing of skin

45 wounds or there is a need to augment the normal healing mechanisms, e.g., bums. One important advantage to using CTGF protein to accelerate wound healing is attributable to the molecule's high percentage of cysteine residues. CTGF, or functional fragments thereof, is more stable and less sus50 ceptible to protease degradation than PDGF and other growth factors known to be involved in wound healing.

CTGF is produced by endothelial cells and fibroblastic cells, both of which are present at the site of a skin wound. Therefore, agents which stimulate the production of CTGF 55 can be added to a composition which is used to accelerate wound healing. Preferably, the agent of this invention is transforming growth factor beta (TGF- $\beta$ ), however, it is likely that other TGF- $\beta$ family members will also be useful in accelerating wound healing by inducing CTGF. The composition of the invention aids in healing the wound, in part, by promoting the growth of connective tissue. The composition is prepared by combining, in a pharmaceutically acceptable carrier substance, e.g., inert gels or liquids, the purified CTGF and TGF- $\beta$.

The term "cell proliferative disorder" refers to pathological states characterized by the continual multiplication of cells resulting in an overgrowth of a cell population within a tissue. 


\section{1}

The cell populations are not necessarily transformed, tumorigenic or malignant cells, but can include normal cells as well. For example, CTGF may be involved pathologically by inducing a proliferative lesion in the intimal layer of an arterial wall, resulting in atherosclerosis. Instead of trying to reduce risk factors for the disease, e.g., lowering blood pressure or reducing elevated cholesterol levels in a subject, CTGF inhibitors or antagonists of the invention would be useful in interfering with the in vivo activity of CTGF associated with atherosclerosis. CTGF antagonists are useful in treating other disorders associated with overgrowth of connective tissues, such as various fibrotic diseases, including scleroderma, arthritis, alcoholic liver cirrhosis, keloid, and hypertropic scar.

The present invention provides a method to detect the presence of elevated levels of CTGF to be used diagnostically to determine the presence of pathologies characterized by a cell proliferative disorder. For example, a sample suspected of containing CTGF is obtained from a subject, the level of CTGF determined and this level is compared with the level of CTGF in normal tissue. The level of CTGF can be determined by immunoassays using anti-CTGF antibodies, for example. Other variations of such assays which are well known to those skilled in the art, such as radioimmunoassay (RIA), ELISA and immunofluorescence can also be used to determine CTGF levels in a sample. Alternatively, nucleic acid probes can be used to detect and quantitate CTGF mRNA for the same purpose.

The invention also discloses a method for ameliorating diseases characterized by a cell proliferative disorder by treating the site of the disease with an effective amount of a CTGF reactive agent. The term "ameliorate" denotes a lessening of the detrimental effect of the disease-inducing response in the patient receiving therapy. Where the disease is due to an overgrowth of cells, an antagonist of CTGF polypeptide is effective in decreasing the amount of growth factor that can bind to a CTGF specific receptor on a cell. Such an antagonist may be a CTGF specific antibody or functional fragments thereof (e.g., Fab, $\mathrm{F}\left(\mathrm{ab}^{\prime}\right)_{2}$ ). Alternatively, a polynucleotide containing the T $\beta R E$ region of the promoter may be used as a CTGF reactive agent by acting as a competitor for TGF- $\beta$. The treatment requires contacting the site of the disease with the antagonist. Where the cell proliferative disorder is due to a diminished amount of growth of cells, a CTGF reactive agent which is stimulatory is contacted with the site of the disease. For example, TGF- $\beta$ is one such reactive agent. Other agents will be known to those skilled in the art.

When a cell proliferative disorder is associated with the expression of CTGF, a therapeutic approach which directly interferes with the translation of CTGF messages into protein is possible. For example, antisense nucleic acid or ribozymes could be used to bind to the CTGF mRNA or to cleave it. Antisense RNA or DNA molecules bind specifically with a targeted gene's RNA message, interrupting the expression of that gene's protein product. The antisense binds to the messenger RNA forming a double stranded molecule which cannot be translated by the cell. Antisense oligonucleotides of about 15-25 nucleotides are preferred since they are easily synthesized and have an inhibitory effect just like antisense RNA molecules. In addition, chemically reactive groups, such as iron-linked ethylenediaminetetraacetic acid (EDTA$\mathrm{Fe}$ ) can be attached to an antisense oligonucleotide, causing cleavage of the RNA at the site of hybridization. These and other uses of antisense methods to inhibit the in vitro translation of genes are well known in the art (Marcus-Sakura, Anal Biochem 172:289, 1988).

\section{2}

Antisense nucleic acids are DNA or RNA molecules that are complementary to at least a portion of a specific mRNA molecule (Weintraub, Scientific American 262:40, 1990). In the cell, the antisense nucleic acids hybridize to the corresponding mRNA, forming a double-stranded molecule. The antisense nucleic acids interfere with the translation of the mRNA, since the cell will not translate an mRNA that is double-stranded. Antisense oligomers of about 15 nucleotides are preferred, since they are easily synthesized and are 10 less likely to cause problems than larger molecules when introduced into the target CTGF producing cell. The use of antisense methods to inhibit the in vitro translation of genes is well known in the art (Marcus-Sakura, Anal Biochem 172: 289, 1988).

15 Use of an oligonucleotide to stall transcription is known as the triplex strategy since the oligomer winds around doublehelical DNA, forming a three-strand helix. Therefore, these triplex compounds can be designed to recognize a unique site on a chosen gene (Maher et al., Antisense Res Dev 1(3):227, 20 1991; Helene, Anticancer Drug Design 6(6):569, 1991), for example, the T $\beta R E$ region of the CTGF promoter.

Ribozymes are RNA molecules possessing the ability to specifically cleave other single-stranded RNA in a manner analogous to DNA restriction endonucleases. Through the 25 modification of nucleotide sequences which encode these RNAs, it is possible to engineer molecules that recognize specific nucleotide sequences in an RNA molecule and cleave it (Cech, Amer Med Assn 260:3030, 1988). A major advantage of this approach is that, because they are sequence30 specific, only mRNAs with particular sequences are inactivated.

There are two basic types of ribozymes namely, tetrahymena-type (Hasselhoff, Nature 334:585, 1988) and "hammerhead"-type. Tetrahymena-type ribozymes recognize 35 sequences which are four bases in length, while "hammerhead"-type ribozymes recognize base sequences 11-18 bases in length. The longer the recognition sequence, the greater the likelihood that the sequence will occur exclusively in the target mRNA species. Consequently, hammerhead-type 40 ribozymes are preferable to tetrahymena-type ribozymes for inactivating a specific mRNA species and 18-based recognition sequences are preferable to shorter recognition sequences.

The identification of the promoter element of the CTGF 45 gene and specifically, the TGF- $\beta$ responsive/regulatory element (T $\beta$ RE) (5'-GTGTCAAGGGGTC-3' (SEQ ID NO:11); nucleotides -157 to -145 ), provides a source for a screening method for identifying compounds or compositions which affect the expression of CTGF. Thus, in another embodiment, 50 the invention provides a method for identifying a composition which affects CTGF expression comprising incubating components comprising the composition and a TGF- $\beta$ responsive element of the CTGF promoter, wherein the incubating is carried out under conditions sufficient to allow the compo5 nents to interact; and measuring the effect of the composition on CTGF expression. The method further comprises adding TGF- $\beta$, or a TGF- $\beta$ family member reactive with the T $\beta$ RE, to the reaction mixture. Therefore, the method allows identification of TGF- $\beta$ inhibitors, or anti-fibrotic compounds. Pref60 erably, the promoter region used in the screening assays described herein includes nucleotides -823 to +74 , however, smaller regions that include the TGF- $\beta$ responsive element would also be useful in the method of the invention (e.g., -162 to -128 or -154 to -145 ).

The observed effect on CTGF expression may be either inhibitory or stimulatory. For example, the increase or decrease of CTGF activity can be measured by a biological 
13

assay for CTGF, as described in the examples herein (e.g., EXAMPLES 1 and 2). Alternatively, a polynucleotide encoding both the regulatory (promoter) and structural region of CTGF may be inserted into an expression vector and the effect of a composition on transcription of CTGF can be measured, for example, by Northern blot analysis. A radioactive compound is added to the mixture of components, such as $\left[{ }^{32} \mathrm{P}\right]-\mathrm{ATP}$, and radioactive incorporation into CTGF mRNA is measured.

Alternatively, a composition which affects the expression of CTGF can be identified by operably linking a reporter gene with the TGF- $\beta$ responsive region of the promoter of CTGF, incubating the components including the composition being tested, the reporter gene construct and TGF- $\beta$ and assaying for expression of the reporter gene. Such reporter genes will be known to those of skill in the art, and include but are not limited to a luciferase gene, chloramphenicol acetyl transferase gene (CAT assay) or $\beta$-galactosidase gene.

The inducer of the T $\beta \mathrm{RE}$ can be added prior to or following the addition of the composition to be tested. Preferably, it is added after the composition is added. An inducer of this region in the CTGF promoter is preferably TGF $-\beta$, however, it is likely that other members of the TGF- $\beta$ family will also be useful for induction from this element. Other such family members or factors will be known to those of skill in the art.

The method of the invention is preferably performed in an indicator cell. An "indicator cell" is one in which activation of CTGF or the reporter gene can be detected. Examples of mammalian host indicator cells include the pre-B cell line, 70Z/3, Jurkat T, COS, BHK, 293, CHO, HepG2, and HeLa cells. Other cell lines can be utilized as indicator cells, as long as the level of reporter gene can be detected. The cells can be recombinantly modified to contain an expression vector which encodes one or more additional copies of the T $\beta R E$ binding motif, preferably operatively linked to a reporter gene. The cells can also be modified to express CTGF, as described above.

The reporter gene is a phenotypically identifiable marker for detection of stimulation or inhibition of CTGF activation. Markers preferably used in the present invention include the 40 LUC gene whose expression is detectable by a luciferase assay. Examples of markers typically used in prokaryotic expression vectors include antibiotic resistance genes for ampicillin ( $\beta$-lactamases), tetracycline and chloramphenicol (chloramphenicol acetyltransferase). Examples of such markers typically used in mammalian expression vectors, which are preferable for the present invention, include the gene for adenosine deaminase (ADA), aminoglycoside phosphotransferase (neo, G418), dihydrofolate reductase (DHFR), hygromycin-B-phosphotransferase (HPH), thymidine kinase (TK), xanthine guanine phosphoribosyltransferse (XGPRT, gpt) and $\beta$-galactosidase $(\beta$-gal).

In yet another embodiment, the invention provides a method of treating a subject having a cell proliferative disorder associated with CTGF gene expression in a subject, comprising administering to a subject having the disorder a therapeutically effective amount of an agent which modulates CTGF gene expression, thereby treating the disorder. The term "modulate" refers to inhibition or suppression of CTGF expression when CTGF is overexpressed, and induction of expression when CTGF is underexpressed. The term "therapeutically effective" means that amount of CTGF agent which is effective in reducing the symptoms of the CTGF associated cell proliferative disorder.

The agent which modulates CTGF gene expression may be a polynucleotide for example. The polynucleotide may be an antisense, a triplex agent, or a ribozyme, as described above.
14

For example, an antisense may be directed to the structural gene region or to the promoter region of CTGF.

The agent also includes a polynucleotide which includes the T $\beta R E$ of the invention. Preferably this region corresponds to nucleotides -162 to -128 of the CTGF regulatory polypeptide illustrated in FIG. 1B. More specifically, the T $\beta$ RE region corresponds to about -154 to -145 in FIG. 1B (SEQ ID NO:11). These polynucleotides are useful as competitive inhibitors or pseudosubstrates for TGF- $\beta$ or other growth 10 factors which bind to the T $\beta \mathrm{RE}$ and induce CTGF transcription.

Delivery of antisense, triplex agents, ribozymes, competitive inhibitors and the like can be achieved using a recombinant expression vector such as a chimeric virus or a colloidal dispersion system. Various viral vectors which can be utilized for gene therapy as taught herein include adenovirus, herpes virus, vaccinia, or, preferably, an RNA virus such as a retrovirus. Preferably, the retroviral vector is a derivative of a murine or avian retrovirus. Examples of retroviral vectors in 20 which a single foreign gene can be inserted include, but are not limited to: Moloney murine leukemia virus MoMuLV), Harvey murine sarcoma virus (HaMuSV), murine mammary tumor virus (MuMTV), and Rous Sarcoma Virus (RSV). A number of additional retroviral vectors can incorporate mul5 tiple genes. All of these vectors can transfer or incorporate a gene for a selectable marker so that transduced cells can be identified and generated. By inserting a polynucleotide sequence of interest into the viral vector, along with another gene which encodes the ligand for a receptor on a specific 30 target cell, for example, the vector is now target specific. Retroviral vectors can be made target specific by inserting, for example, a polynucleotide encoding a sugar, a glycolipid, or a protein. Preferred targeting is accomplished by using an antibody to target the retroviral vector. Those of skill in the art 5 will know of, or can readily ascertain without undue experimentation, specific polynucleotide sequences which can be inserted into the retroviral genome to allow target specific delivery of the retroviral vector containing the antisense polynucleotide.

40 Since recombinant retroviruses are defective, they require assistance in order to produce infectious vector particles. This assistance can be provided, for example, by using helper cell lines that contain plasmids encoding all of the structural genes of the retrovirus under the control of regulatory 45 sequences within the LTR. These plasmids are missing a nucleotide sequence which enables the packaging mechanism to recognize an RNA transcript for encapsidation. Helper cell lines which have deletions of the packaging signal include but are not limited to $\Psi 2, \mathrm{PA} 317$ and PA12, for 50 example. These cell lines produce empty virions, since no genome is packaged. If a retroviral vector is introduced into such cells in which the packaging signal is intact, but the structural genes are replaced by other genes of interest, the vector can be packaged and vector virion produced.

Alternatively, NIH 3T3 or other tissue culture cells can be directly transfected with plasmids encoding the retroviral structural genes gag, pol and env, by conventional calcium phosphate transfection. These cells are then transfected with the vector plasmid containing the genes of interest. The resulting cells release the retroviral vector into the culture medium.

Another targeted delivery system for antisense polynucleotides a colloidal dispersion system. Colloidal dispersion systems include macromolecule complexes, nanocapsules, 5 microspheres, beads, and lipid-based systems including oilin-water emulsions, micelles, mixed micelles, and liposomes. The preferred colloidal system of this invention is a liposome. 


\section{US 7,384,634 B2}

15

Liposomes are artificial membrane vesicles which are useful as delivery vehicles in vitro and in vivo. It has been shown that large unilamellar vesicles (LUV), which range in size from $0.2-4.0 \mu \mathrm{m}$ can encapsulate a substantial percentage of an aqueous buffer containing large macromolecules. RNA, DNA and intact virions can be encapsulated within the aqueous interior and be delivered to cells in a biologically active form (Fraley et al., Trends Biochem Sci 6:77, 1981). In addition to mammalian cells, liposomes have been used for delivery of polynucleotides in plant, yeast and bacterial cells. In order for a liposome to be an efficient gene transfer vehicle, the following characteristics should be present: (1) encapsulation of the genes of interest at high efficiency while not compromising their biological activity; (2) preferential and substantial binding to a target cell in comparison to non-target cells; (3) delivery of the aqueous contents of the vesicle to the target cell cytoplasm at high efficiency; and (4) accurate and effective expression of genetic information (Mannino et al., Biotechniques 6:682, 1988).

The composition of the liposome is usually a combination of phospholipids, particularly high-phase-transition-temperature phospholipids, usually in combination with steroids, especially cholesterol. Other phospholipids or other lipids may also be used. The physical characteristics of liposomes depend on $\mathrm{pH}$, ionic strength, and the presence of divalent cations.

Examples of lipids useful in liposome production include phosphatidyl compounds, such as phosphatidylglycerol, phosphatidylcholine, phosphatidylserine, phosphatidylethanolamine, sphingolipids, cerebrosides, and gangliosides. Particularly useful are diacylphosphatidylglycerols, where the lipid moiety contains from 14-18 carbon atoms, particularly from 16-18 carbon atoms, and is saturated. Illustrative phospholipids include egg phosphatidylcholine, dipalmitoylphosphatidylcholine and distearoylphosphatidylcholine.

The targeting of liposomes has been classified based on anatomical and mechanistic factors. Anatomical classification is based on the level of selectivity, for example, organspecific, cell-specific, and organelle-specific. Mechanistic targeting can be distinguished based upon whether it is pas- 40 sive or active. Passive targeting utilizes the natural tendency of liposomes to distribute to cells of the reticulo-endothelial system (RES) in organs which contain sinusoidal capillaries. Active targeting, on the other hand, involves alteration of the liposome by coupling the liposome to a specific ligand such as 45 a monoclonal antibody, sugar, glycolipid, or protein, or by changing the composition or size of the liposome in order to achieve targeting to organs and cell types other than the naturally occurring sites of localization.

The surface of the targeted delivery system may be modi- 50 fied in a variety of ways. In the case of a liposomal targeted delivery system, lipid groups can be incorporated into the lipid bilayer of the liposome in order to maintain the targeting ligand in stable association with the liposomal bilayer. Various linking groups can be used for joining the lipid chains to the targeting ligand. In general, the compounds bound to the surface of the targeted delivery system will be ligands and receptors which will allow the targeted delivery system to find and "home in" on the desired cells. A ligand may be any compound of interest which will bind to another compound, such as a receptor. The agent which modulates CTGF gene expression in the method of the invention includes agents which cause an elevation in cyclic nuclotides in the cell. For example, agents such as cholera toxin or 8Br-cAMP are preferably administered to a subject having a cell proliferative disorder associated with CTGF gene expression. Preferably, the cyclic nucleotide that is elevated after treatment in the
16

method of the invention is cAMP or a cAMP analog, either functional or structural, or both. Those of skill in the art will know of other agents which induce cAMP or similar analogs in a cell and which are useful in the method of the invention.

The therapeutic agents useful in the method of the invention can be administered parenterally by injection or by gradual perfusion over time. Administration may be intravenously, intraperitoneally, intramuscularly, subcutaneously, intracavity, or transdernally.

Preparations for parenteral administration include sterile aqueous or non-aqueous solutions, suspensions, and emulsions. Examples of non-aqueous solvents are propylene glycol, polyethylene glycol, vegetable oils such as olive oil, and injectable organic esters such as ethyl oleate. Aqueous carriers include water, alcoholic/aqueous solutions, emulsions or suspensions, including saline and buffered media. Parenteral vehicles include sodium chloride solution, Ringer's dextrose, dextrose and sodium chloride, lactated Ringer's intravenous vehicles include fluid and nutrient replenishers, electrolyte

replenishers (such as those based on Ringer's dextrose), and the like. Preservatives and other additives may also be present such as, for example, antimicrobials, anti-oxidants, chelating agents and inert gases and the like.

The invention also includes a pharmaceutical composition comprising a therapeutically effective amount of CTGF in a pharmaceutically acceptable carrier. Such carriers include those listed above with reference to parenteral administration.

The present Examples (see EXAMPLE 10) demonstrate that TGF- $\beta$ induction of CTGF is cell type specific (e.g., fibroblast). Consequently, the CTGF promoter region, including the $\mathrm{T} \beta \mathrm{RE}$, is useful for the expression of a structural gene specifically in connective tissue cells. It is envisioned that any gene product of interest can be specifically produced in a connective tissue cell, once operably linked to the T $\beta R E$,

35 and in the presence of TGF- $\beta$. For example, it may be desirable to operably link PDGF or another growth factor to a polynucleotide containing T $\beta \mathrm{RE}$, thereby specifically producing PDGF or another factor in a connective tissue cell. Alternatively, in cases where the level of CTGF or other factor 40 produced is elevated, it may be desirable to introduce an antisense for CTGF, for example, under control of T $\beta R E$, thereby decreasing the production of CTGF in the cell.

The following examples are intended to illustrate but not limit the invention. While they are typical of those that might be used, other procedures known to those skilled in the art may alternatively be used.

\section{EXAMPLE 1}

\section{Identification And Partial Purification Of Mitogen} From HUVE Cells PDGF-Immunorelated

\section{Cells}

Human umbilical vein endothelial (HOVE) cells were isolated from fresh human umbilical cords by collagenase perfusion (Jaffe et al., Human Pathol 18:234, 1987) and maintained in medium 199 with $20 \% \mathrm{FCS}, 0.68 \mathrm{mM} \mathrm{L}$-glutamine, $20 \mu \mathrm{g} / \mathrm{ml}$ Gentamicin, $90 \mu \mathrm{g} / \mathrm{mI}$ porcine heparin (Sigma, St. 60 Louis Mo.), and $50 \mu \mathrm{g} / \mathrm{ml}$ Endothelial Cell Growth Supplement (Sigma). Cells used for media collection were third passage cells. Cells were identified as endothelial cells by their non-overlapping cobblestone morphology and by positive staining for Factor-VIII related antigen. NRK cells were 5 obtained from American Type Culture Collection (ATCC, Manassas Va.); NIH-3T3 cells were a gift from S. Aaronson (NCI, Bethesda $\mathrm{Md}$.), and both cell lines were maintained in 
17

DMEM, $10 \% \mathrm{FCS}, 20 \mu \mathrm{g} / \mathrm{ml}$ Gentamicin. Fetal bovine aortic smooth muscle cells were obtained from tissue explants as previously described (Grotendorst et al., Proc Natl Acad Sci USA, 78:3669, 1981) and maintained in DMEM, 10\% FCS, $20 \mu \mathrm{g} / \mathrm{ml}$ Gentamicin, and used in assays at second or third passage.

Growth Factors and Antibodies

Human PDGF was purified to homogeneity from platelets as described previously (Grotendorst, Cell 36:279, 1984). Recombinant $\mathrm{AA}, \mathrm{BB}$, and $\mathrm{AB}$ chain dimeric PDGF molecules were obtained from Creative Biomolecules (Hopkinton Mass.). FGF was obtained from Sigma. Purified PDGF or synthetic peptides containing the amino and carboxyl sequences of the mature PDGF $A$ and $B$ chain molecules were used to raise antibodies in goats. Goats were immunized with $20 \mu \mathrm{g}$ of purified PDGF or $50 \mu \mathrm{g}$ of synthetic peptide in Freunds complete adjuvant by multiple intradermal injections. Immune sera were collected seven days after the fourth rechallenge (in Freunds incomplete adjuvant) and subsequent rechallenges. The anti-PDGF antibody did not show any cross-reactivity to TGF- $\beta$, EGF, or FGF in immunoblot analysis. The anti-peptide antibodies were sequence specific and did not cross-react with other synthetic peptide sequences or with recombinant PDGF peptides which did not contain the specific antigenic sequence. This was determined by Western blot and dot blot analysis.

\section{Antibody Affinity Column}

Goat anti-human PDGF IgG (150 mg) was covalently bound to $25 \mathrm{mls}$ of Affi-Gel 10 support (Bio-Rad, Hercules Calif.) according to the manufacturers instructions with a final concentration of $6 \mathrm{mg} \mathrm{IgG/ml} \mathrm{gel.} \mathrm{The} \mathrm{column} \mathrm{was}$ incubated with agitation at $4^{\circ} \mathrm{C}$. for 18 hours with 1 liter of HUVE cell media which had been conditioned for 48 hours. The gel was then poured into a column $(5 \times 1.5 \mathrm{~cm})$, washed with four volumes of $0.1 \mathrm{~N}$ acetic acid made $\mathrm{pH} 7.5$ with ammonium acetate, and the antibody-bound PDGF immunoreactive proteins eluted with IN acetic acid. Peak fractions were determined by biological assays and immunoblotting and the fractions pooled.

Initial studies of the PDGF-related growth factors secreted by HVE cells were done by removing the serum containing growth media from confluent cultures of cells and replacing it with serum-free media. Aliquots of this media were removed periodically and the proteins immunoblotted using an antibody specific for human platelet PDGF. This antibody does not cross-react with any other known growth factors and is able to detect less than 500 picograms of dimeric PDGF or 10 nanograms of reduced, monomeric $\mathrm{A}$ or $\mathrm{B}$ chain peptide on irnmunoblots. HUVE cells were grown to confluence in 6 well plates. The growth media was removed, cells washed with PBS and $1 \mathrm{ml}$ of serum-free media was added to each well. The media was removed after conditioning for the period of time from 6-48 hours, dialyzed against $1 \mathrm{~N}$ acetic acid and lyophilized. The samples were then run on $12 \%$ PAGE, electroblotted to nitrocellulose and visualized with the anti-human PDGF antibody. Five nanograms of purified platelet PDGF was run as reference.

The results indicated constitutive secretion of several species of molecules which are immunologically similar to platelet PDGF but are of higher relative molecular weight (36-39 $\mathrm{kD}$ ) than the expected $30-32 \mathrm{kD}$ MW of platelet PDGF or $\mathrm{A}$ chain or B chain homodimers. Chemotactic and mitogenic assays performed with this serum-free conditioned media indicated the total biological activity present was equivalent to $15 \mathrm{ng} / \mathrm{ml}$ of platelet PDGF after a 48 hour conditioning period. Incubation of the media with $30 \mu \mathrm{g} / \mathrm{ml}$ of anti-human
18

PDGF IgG neutralized approximately $20-30 \%$ of the mitogenic activity and similar amount of the chemotactic activity.

The presence in HUVE culture media of several species of PDGF immunoreactive molecules was unexpected, particularly molecules of higher molecular weight than those of the $A$ and $B$ chain dimeric molecules anticipated to be produced and secreted by endothelial cells (Collins et al., Nature 328: 621-624, 1987; Sitaras et al., Cell Physiol 132:376-380, 1987). In order to obtain greater amounts of the PDGF-like 10 proteins for further analysis, the HUVE cells had to be kept in media containing $20 \%$ fetal calf serum, since the cells begin to die after 24 hours in serum-free or low serum media. The PDGF immunoreactive proteins were partially purified from the serum containing media by use of an antibody affinity 5 column made with the anti-human PDGF IgG and an Affi-Gel 10 support (Bio-Rad). Mitogenic assays were performed using NRK cells as target cells $\mathrm{PDGF} B \mathrm{BB}=5 \mathrm{ng} / \mathrm{ml}$, PDGF $\mathrm{AA}=10 \mathrm{ng} / \mathrm{ml}$ ). HUVE media was $250 \mu \mathrm{l}$ of HUVE cell serum-free conditioned media (48 hours) which was dialyzed 20 against $1 \mathrm{~N}$ acetic acid, lyophilized, and resuspended in DMEM before addition to test wells. Affinity purified fraction was $5 \mu 1 / \mathrm{ml}$ of combined, concentrated major pool from AffiGel 10 affinity column. Anti-PDGF IgG or non-immune IgG $(30 \mu \mathrm{g} / \mathrm{ml})$ was added to the samples and incubated 18 hours at $4^{\circ} \mathrm{C}$. prior to testing in the mitogenic assay. The mean of triplicate samples was determined and the standard deviation was less than $5 \%$. The experiments were repeated at least three times with similar results.

When aliquots of the partially purified proteins were 30 assayed for chemotactic and mitogenic activity, all biological activity could be neutralized by prior incubation of the proteins with the anti-human PDGF antibody. This indicated that the only biologically active molecules present in the partially purified media proteins were PDGF immunorelated mol5 ecules.

Aliquots of the partially purified proteins were immunoblotted using the same anti-PDGF antibody and the data indicated the presence of the higher MW molecules observed in the serum-free conditioned media. The major species 40 secreted migrates on polyacrylamide gels at $36 \mathrm{kD}$ and comprises at least $50 \%$ of the total immunoreactive protein purified from conditioned media. The immunoreactive species migrating at 37 and $39 \mathrm{kD}$ constitute most of the remaining immunoreactive protein. A similar pattern was seen with 45 proteins labeled with $\left[{ }^{35} \mathrm{~S}\right]$-cysteine and affinity purified with the anti-PDGF $\operatorname{IgG}$ immunoaffinity column. Less than $15 \%$ of the total affinity purified proteins co-migrated with purified platelet PDGF or recombinant PDGF isoforms.

Prior incubation of the antibody with purified PDGF (300 $50 \mathrm{ng}$ PDGF/2 $\mu \mathrm{g} \operatorname{IgG}$ ) blocked antibody binding to all of the molecules, indicating shared antigenic determinants with dimeric platelet PDGF. Interestingly, when the antibody was blocked with recombinant $\mathrm{AA}, \mathrm{BB}$, or $\mathrm{AB}$ dimers, antibody binding to the HUVE secreted proteins was inhibited equally 55 by all three dimeric forms, suggesting that the antibody recognizes common epitopes present on all three PDGF dimers and the HWE secreted molecules. In order to insure that none of the antibody binding molecules detected on Western blots was derived from fetal calf serum or other additives in the culture media, a new, unused antibody affinity column was made and media which was never conditioned by cells was processed exactly as the conditioned media. No PDGF inmrunoreactive molecules were detected in the fractions from this column by immunoblot and no biological activity was detected. When platelet PDGF or the recombinant dimers are reduced with $200 \mathrm{mM}$ dithiothreitol (DTT), monomeric A chain $(17 \mathrm{kD})$ and $B$ chain $(14 \mathrm{kD})$ peptides are observed on 
19

immunoblots. Treating the HWE molecules in a $100 \mathrm{mM}$ DTT sample buffer resulted in slower migration of the major immunoreactive peptides on polyacrylamide gels. Most of the immunoreactive molecules migrated at $38-39 \mathrm{kD}$ and less intense bands were observed at 25 and $14 \mathrm{kD}$. It was necessary to run at least 10 times as much reduced protein as nonreduced in order to detect the reduced molecules. This is consistent with the affinity of the antibody for monomeric forms of the PDGF A and B chain peptides. These data indicate that the major species in the PDGF-related affinity purified proteins from conditioned media of HUVE cells was monomeric peptide which migrates on acrylamide gels at an apparent molecular weight of $36 \mathrm{kD}$ nonreduced and $38 \mathrm{kD}$ when reduced.

\section{EXAMPLE 2}

\section{Biological Assays}

Chemotactic activity was determined in the Boyden chamber chemotaxis assay with NIH 3T3 or bovine aortic smooth muscle (BASM) cells as described (Grotendorst et al., Proc Natl Acad Sci USA 78:3669-3672, 1981; Grotendorst et al., Meth Enzymol 147:144-152, 1987). Mitogenic assays were performed using 96 well plates and normal rat kidney (NRK) fibroblasts or NIH 3T3 cells as target cells. The cells were plated in DMEM, 10\% FCS; NRK cell cultures were used 10-14 days after confluence and $3 \mathrm{~T} 3$ cells made quiescent by incubation for 2 days in serum-free DMEM, $0.2 \mathrm{mg} / \mathrm{ml} \mathrm{BSA}$ before use. Sample proteins and dilutions of known standards were added to the wells and the plates incubated at $37^{\circ} \mathrm{C}$. in $10 \% \mathrm{CO}_{2}, 90 \%$ air for 18 hours, after which $\left[{ }^{3} \mathrm{H}\right]$-thymidine at a final concentration of $5 \mathrm{uCi} / \mathrm{mi}$ was added and incubated for an additional 2 hours. The media was removed, the cells washed and DNA synthesis determined from the $\left[{ }^{3} \mathrm{H}\right]$-thymidine incorporation into trichloroacetic acid precipitable material by scintillation counting.

Gel Electrophoresis and Immunoblotting

Electrophoresis was performed on $12 \%$ polyacrylamide gels containing SDS (Laemmli, Nature 227:680-685, 1970) unless otherwise stated. Irnmunoblotting was performed by electroblotting the proteins to a nitrocellulose membrane and incubating the membrane in $50 \mathrm{mM}$ Tris- $\mathrm{HCl}, \mathrm{pH} 7.4,100$ $\mathrm{mM} \mathrm{NaCl}$ (TBS) with $5 \%$ non-fat dry milk at $25^{\circ} \mathrm{C}$. for 1 hour to block non-specific antibody binding. The blocking solution was removed and the antibody $(15 \mu \mathrm{g} / \mathrm{ml})$ added in TBS containing $0.5 \%$ non-fat dry milk and $1 \mu \mathrm{g} / \mathrm{ml}$ sodium azide and incubated overnight at $25^{\circ} \mathrm{C}$. The membranes were washed 5 times in TBS, $0.5 \%$ milk for 10 minutes each wash and then incubated with alkaline phosphatase conjugated affinity purified rabbit anti-goat IgG (KPL, Gaithersburg Md.) at a $1: 1000$ dilution in TBS containing $0.5 \%$ milk at $25^{\circ}$ C. for 1 hour. The filters were washed with TBS five times, 10 minutes each time, and the blot developed using an alkaline phosphatase substrate solution $(0.1 \mathrm{M}$ Tris- $\mathrm{HCl}, \mathrm{pH} 9,0.25$ $\mathrm{mg} / \mathrm{ml}$ nitro blue tetrazolium, $0.5 \mathrm{mg} / \mathrm{ml} 5$ bromo-4-chloro3-indolyl phosphate).

Major Chemotactic and Mitogenic Activity is Produced by 36 kD Peptide and Not PDGF Peptides

In order to determine if the chemotactic and mitogenic activities observed in the partially purified media proteins were from molecules containing the PDGF $\mathrm{A}$ and $\mathrm{B}$ chain peptides or were the products of molecules which do not contain these sequences, biological assays were performed with serial dilutions of the affinity purified media proteins and serial dilutions of recombinant $\mathrm{PDGF} A \mathrm{~A}$ and $\mathrm{BB}$
20

homodimers and the $\mathrm{AB}$ heterodimer. Sufficient quantities of the samples were prepared to perform the mitogenic and chemotactic assays and the immunoblots with aliquots of each dilution sample. The mitogenic activity of the HUVE affinity purified factors observed was comparable to the activity elicited by all three recombinant PDGF dimers. The chemotactic activity was comparable to the $\mathrm{AB}$ heterodimer, producing less response than the $\mathrm{BB}$ homodimer and greater response than the AA homodimer. When the biological activ10 ity of the samples was compared with immunoblots of equivalent amounts of the same samples, no A chain nor B chain molecules were detected in the test samples. These data demonstrate the major biological activity present in the antiPDGF affinity purified fraction cannot be accounted for by

15 PDGF A or B chain containing molecules and imply that the major PDGF-immunoreactive protein species! present in these samples (the $36 \mathrm{kD}$ peptide) is biologically active and does not contain amino acid sequences found in the amino and carboxy terminals of the PDGF A or B chain peptides.

\section{EXAMPLE 3}

\section{Receptor Competition Assays}

25 Assays were performed using confluent cultures of NIH $3 \mathrm{~T} 3$ cells in 24 well plates (Corning Costar, Acton Mass.) grown in DMEM, $10 \%$ fetal calf serum, $10 \mu \mathrm{g} / \mathrm{ml}$ Gentamicin. The growth media was removed and the cells washed twice with serum-free DMEM, $0.2 \mathrm{mg} / \mathrm{ml} \mathrm{BSA}$ and the plates 30 placed on ice for 30 minutes in serum-free DMEM, $0.2 \mathrm{mg} / \mathrm{ml}$ BSA. Test samples and controls were made up in serum-free DMEM, $0.2 \mathrm{mg} / \mathrm{ml}$ BSA containing $5-10 \mathrm{ng} / \mathrm{ml}$ of HUVE affinity purified proteins and a serial dilution of one of the recombinant $\mathrm{PDGF}$ isoforms in a concentration range of 300 $35 \mathrm{ng} / \mathrm{ml}$ to $16 \mathrm{ng} / \mathrm{ml}$. One milliliter aliquots of the samples were placed into wells of the 24 well plates and incubated on ice on a platform rocker for two hours. After the incubation period, the cells were washed three times for 10 minutes each on ice with PBS. The proteins bound to the surface of the cells were 40 eluted with $5 \mu 1$ of IN acetic acid for 10 minutes. The acetic acid elution samples were lyophilized, resuspended in $5 \mathrm{mM}$ HCL, run on $12 \%$ polyacrylamide gels and immunoblotted to nitrocellulose using the anti-PDGF antibody.

In order to substantiate the binding of the endothelial cell 45 molecules to the PDGF cell surface receptors, competitive receptor binding assays were performed. Because immunoblots of the affinity purified HUVE cell secreted proteins indicated the presence of multiple PDGF immunoreactive molecules, $\left[{ }^{125} \mathrm{I}\right]$-labeled PDGF competition assays could not be 50 used since this would not indicate which molecules in this mixture were competing for binding of the labeled PDGF for the receptors on the target cells. Since the isoforms of PDGF and the major PDGF immunorelated protein secreted by HUVE cells are of different molecular weights, receptor 55 binding competition was demonstrated on immunoblots. Direct binding of the anti-PDGF immunoreactive peptides to NIH 3 T3 cells was demonstrated by incubating monolayers of the $3 \mathrm{~T} 3$ fibroblasts with the anti-PDGF affinity purified proteins $(10 \mathrm{ng} / \mathrm{ml})$ for 2 hours at $4^{\circ} \mathrm{C}$. Bound peptides were 60 released by washing of the cell layer with $1 \mathrm{~N}$ acetic acid and quantitated by immunoblot analysis using anti-PDGF IgG. This data show that the $36 \mathrm{kD}$ immunoreactive peptide binds to cell surface of NIH 3 T3 cells. This binding can be competed by increasing concentrations of recombinant $\mathrm{PDGF} B \mathrm{BB}$ 65 added to the binding media. These data suggest that the CTGF peptide binds to specific cell surface receptors on NIH $3 \mathrm{~T} 3$ cells and that PDGF BB can compete with this binding. 
21

RNA Isolation and Northern Blotting

Total RNA was isolated from cells in monolayer culture cells. Lyophilized RNA was resuspended in gel loading buffer containing $50 \%$ formamide and heated at $95^{\circ} \mathrm{C}$. for two minutes before loading ( $20 \mu \mathrm{g}$ per lane total RNA) onto $2.2 \mathrm{M}$ formaldehyde, $1 \%$ agarose gels and run at 50 volts. Integrity of RNA was determined by ethidium bromide staining and visualization of $18 \mathrm{~S}$ and $28 \mathrm{~S}$ rRNA bands. After electrophoresis the RNA was transferred to nitrocellulose by blotting overnight with $10 \times \mathrm{SSC}$ buffer. The nitrocellulose was air dried and baked at $80^{\circ} \mathrm{C}$. for 2 hours in a vacuum oven. Hybridization was performed overnight at $46^{\circ} \mathrm{C}$. with the addition of $5 \times 10^{5} \mathrm{CPM}$ per $\mathrm{ml}$ of $\left[{ }^{32} \mathrm{P}\right]$-labeled probe. Normally for Northern blots, the entire plasmid was labeled and used as a probe. Labeling was done with a random primer labeling kit from Boehringer Mannheim. After hybridization, membranes were washed twice in $2 \times \mathrm{SSC}, 0.1 \%$ SDS for 15 minutes each at room temperature, once for 15 minutes in $0.1 \times \mathrm{SSC}, 0.1 \% \mathrm{SDS}$, room temperature and a final $15 \mathrm{~min}-$ utes wash in $0.1 \times \mathrm{SSC}, 0.1 \% \mathrm{SDS}$ at $46^{\circ} \mathrm{C}$. Blots were autoradiographed at $-70^{\circ} \mathrm{C}$. on Kodak X-omat film.

\section{EXAMPLE 4}

\section{Library Screening, Cloning, And Sequencing}

Standard molecular biology techniques were used to subclone and purify the various DNA clones (Sambrook et al., Molecular Cloning: A Laboratory Manual, Second edition, Cold Spring Harbor Laboratory Press, Cold Spring Harbor N.Y., 1989). Clone DB60 was picked from a lambda gt11 HUVE cell cDNA library by induction of the fusion proteins and screening with anti-PDGF antibody. Plaques picked were rescreened and positive clones replated at low titer and isolated.

The EcoR I insert from clone DB60 was cloned into the M13 phage vector and single-stranded DNA obtained for clones with the insert in opposite orientations. These M13 clones were then sequenced by the dideoxy method using the Sequenase kit (U.S. Biochemical, Cleveland Ohio) and $\left[{ }^{35} \mathrm{~S}\right]-$ dATP (DuPont, Newton Mass.). Both strands of DNA for this clone were completely sequenced using primer extension and both GTP and ITP chemistry. Aliquots of the sequencing reactions were run on both $6 \%$ acrylamide (16 hours) and $8 \%$ acrylamide ( 6 hours) gels, vacuum dried and autoradiographed for at least 18 hours.

The cDNA fragment from clone DB60 was $\left[{ }^{32} \mathrm{P}\right]-\mathrm{CTP}$ labeled and used to rescreen the HUVE cell cDNA lambda gt11 library. Several clones were picked and the largest, the 2100 bp clone designed DB60R32, was subcloned into BLUESCRIPT phagemid (Stratagene, La Jolla Calif.). Subclones were made of PstI, KpnI, and EcoRI/KpnI restriction fragments also in BLUESCRIPT phagemid (Stratagene). These subdiones were sequenced by double-stranded plasmid DNA sequencing techniques using Sequenase as described above. The $1458 \mathrm{bp}$ Eco RI/KpnI clone containing the open reading frame was subcloned into M13 mp 8 and M113 mp 19 and both strands of DNA were completely sequenced using single-stranded DNA sequencing techniques with primer extension and both GTP and ITP chemistry.

Cloning Expression and Sequencing of the cDNA for Connective Tissue Growth Factor

In order to further characterize these PDGF related molecules, sufficient quantities of the CTGF protein for amino acid sequencing was needed. However, the low concentrations of CTGF in the conditioned media of HUVE cell cul-
22

tures and the costly and time consuming techniques involved in obtaining and culturing these cells made protein purification to homogeneity and amino acid sequencing impractical. Therefore, the anti-PDGF antibody was used to screen an HUVE cell CDNA library made in the expression vector lambda gt11. Over 500,000 recombinant clones were screened. Several clones which gave strong signals with the anti-PDGF antibody in the screening process were purified and subcloned into the M13 phage vector and partial 10 sequence data obtained by single-stranded DNA sequencing. A search of the GenBank DNA sequence data base indicated that two of the clones picked contained fragments of the PDGF B chain CDNA open reading frame sequence. One of these clones was similar to a $1.8 \mathrm{~kb}$ insert previously isolated 5 by Collins et al. (Nature 316:748-750, 1985) using a c-sis CDNA probe. A third clone of 500 bp was completely sequenced and no match was found in a homology search of all nucleotide and amino acid sequences in GenBank (CEF 10 sequence was not available at that time). This clone was 20 designated DB60. Anti-PDGF antibody binding to the fusion protein produced by the clone DB60 was completely blocked by the affinity purified proteins. A $\left[{ }^{32} \mathrm{P}\right]$-labeled probe was made of DB60 and used on a Northern blot of $20 \mu \mathrm{g}$ of total RNA isolated from HUVE cells. The blot indicated probe

25 hybridization with an mRNA of 2.4 kilobases, which is a message of sufficient size to produce the proteins in the $38 \mathrm{kD}$ molecular weight range seen on the immunoblots of the affinity purified proteins. The DB60 clone was used to rescreen the HUVE cell cDNA lambda gt11 library and the largest clone isolated contained a 2100 base pair insert designated DB60R32. A probe made with the $2100 \mathrm{bp}$ Eco RI insert of clone DB60R 32 also hybridized with a single $2.4 \mathrm{~kb}$ message in a Northern blot of total RNA from HUVE cells.

\section{EXAMPLE 5}

In Vitro Transcription And Translation

In vitro transcription reactions were done using the 2100 40 bp cDNA clone DB60R32 in the BLUESCRIPT KS vector (Stratagene). The plasmid was cut with Xho I which cuts the plasmid once in the multiple cloning site of the vector 3 to the cDNA insert. The T7 promoter site located 5 ' to the cDNA insert was used for transcription. The in vitro transcriptions 45 were done with a kit supplied with the BLUESCRIPT vector (Stratagene).

In vitro translation reactions were done using nuclease treated rabbit reticulocyte lysate and $\left[{ }^{35} \mathrm{~S}\right]$-cysteine in a cysteine-free amino acid mix for labeling of the peptide 50 (Promega, Madison Wis.). The reactions were done in a final volume of $50 \mu 1$ containing $\left[{ }^{35} \mathrm{~S}\right]$-cysteine $1 \mathrm{mCi} / \mathrm{ml}(1200$ $\mathrm{Ci} / \mathrm{mMole}$, DuPont), and serial dilutions of mRNA from the in vitro transcription reactions in concentrations ranging from 50 to 500 nanograms per reaction tube. The reactions were 55 incubated at $30^{\circ} \mathrm{C}$. for 60 minutes. Aliquots of the reactions were run on reduced or nonreduced $12 \%$ polyacrylamide electrophoresis gels, dried, and autoradiographed.

Bacterial expression of immunoreactive CTGF peptide was accomplished by subcloning clone DB60R32 into the 60 Eco RI site of the pET 5 expression vector (Studier et al., Methods Enzymol 185, 60-89, 1990) in both sense and inverse orientations (as determined by restriction enzyme digest analysis). Cultures of E. coli HMS174 cells were grown in M9 media to an OD 600 of 0.7 and the media made $650.4 \mathrm{mM}$ IPTG and incubation continued for 2 hours. The cells were pelleted, lysed, inclusion bodies removed by centrifugation and aliquots of the pellet extracts run on $12 \%$ poly- 
23

acrylamide gels and immunoblotted using the anti-PDGF antibody. The protein produced by clone DB60R32 in the sense orientation produced anti-PDGF immunoreactive peptides in the $36-39 \mathrm{kD}$ MW range while the anti-sense control produced no immunoreactive peptides. The recombinant peptides produced in the $E$. coli system completely blocked the anti-PDGF reaction with the CTGF peptides present in conditioned media.

\section{Expression of CTGF in Xenopus}

For expression in Xenopus oocytes, mature $X$. laevis females were obtained from Nasco (Fort Atkinson Wis.) and maintained at room temperature. Frogs were anesthetized by hypothermia and the ovarian tissue was surgically removed. Ovarian tissue was minced and digested the $0.2 \%$ collagenase (Type II; Sigma) in OR-2 without calcium (Wallace et al., Exp Zool 184:321-334, 1973) for 2-3 hours. Unblemished stage VI oocytes (Dumont, Morphol 136:153-180, 1972), $1.3 \mathrm{~mm}$ diameter, were then carefully selected and microinjected.

Stage VI oocytes (5-10 at a time) were placed on a hollowed plexiglass platform and drained of excess OR-2 solution. Approximately $50 \mathrm{nl}$ of sample containing $10 \mathrm{ng}$ of RNA was injected into the animal pole just above the oocyte equator using a LEITZ MICROINJECTOR system (Leica Microsystems Inc., Bannockburn Ill.). Following injection, oocytes were returned to OR-2 buffer with $0.1 \%$ BSA and incubated for 24 hours at $25^{\circ} \mathrm{C}$. Viable oocytes were then pooled and extracted by homogenization in $100 \mathrm{~mm} \mathrm{NaCl}, 10 \mathrm{~mm}$ Tris $\mathrm{pH} 7.5$ with ten strokes of a Dounce homogenizer $(20 \mu 1 / \mathrm{oo}-$ cyte). The homogenate was then mixed with an equal volume of freon to remove pigment and lipid and centrifuged at $10,000 \mathrm{rpm}$ for 30 seconds to separate the phases. The top aqueous phase was removed and tested for chemotactic activity using NIH 3 T3 cells as described above.

Injection of Xenopus oocytes with $10 \mathrm{ng}$ of RNA preparations derived by in in vitro transcription of the DB60 R32 clone resulted in the production of a fibroblast chemotactic activity. Control injected cells did not produce this activity. These results indicate that the open reading frame of the DB60 R32 clone encodes a protein with chemotactic activity for fibroblastic cells as does CTGF.

\section{EXAMPLE 6}

\section{Sequence Analysis of CTGF}

The $2100 \mathrm{bp}$ insert of clone DB60R32 was sequenced initially by subcloning of PstI and KpnI restriction fragments into Bluescript and using double-stranded dideoxy methods. This indicated an open reading frame of 1047 base pairs and oriented the DB60 insert to the larger cDNA. An Eco RI/KpnI fragment containing the entire open reading frame was inserted into M13 mp 18 and M13 mp 19 and both strands of the DNA were sequenced with single-stranded dideoxy methods by primer extension using both GTP and the GTP analog ITP. The cDNA nucleotide sequence of the open reading frame encoded a $38,000 \mathrm{MW}$ protein, confirming the cell-free translation results and matching the size of the immunopurified peptides. A new search of the GenBank data base revealed that this cDNA had a $50 \%$ nucleotide sequence homology with CEF-10 mRNA, one of the immediate early genes induced in v-src transformed chicken embryo fibroblasts (Simmons et al., Proc Natl Acad Sci USA 86:1178$1182,1989)$. The translated cDNA for human CTGF and avian CEF-10 have a $45 \%$ overall homology and a $52 \%$ homology if the putative alternative splicing region is deleted. This region is between amino acids 171 (aspartic acid) and 199 (cysteine) in the CTGF sequence.

\section{4}

EXAMPLE 7

\section{Analysis Of CTGF Promoter Region}

5 Cell Cultures

Human skin fibroblasts were grown from explants of skin biopsy specimens. NIH/3T3 cells and Cos 7 cells were obtained from the ATCC. All cells were cultured in Dulbecco's modified eagle's medium (DMEM) contained $10 \%$ fetal calf serum (FCS) at $37^{\circ} \mathrm{C}$. in an atmosphere of $10 \% \mathrm{CO}_{2}$ and $90 \%$ air. Human skin fibroblasts were used prior to the sixth passage.

Growth Factors

TGF- $\beta 1$ was a gift from Richard Assoian (University of Miami). Recombinant PDGF BB was obtained from Chiron (Emeryville Calif.). Purified murine EGF was purchased from Sigma.

RNA Isolation and Northern Blotting

Total RNA was isolated from cultured cells by acid guanidium thiocyanate-phenolchloroform extraction as reported previously (Chomczynski et al., Birchem 162:156$159,1987)$. Total RNA was electrophoresed on a $1.5 \%$ agarose/formaldehyde gel and transferred to nitrocellulose. The CTGF probe as $1.1 \mathrm{~kb}$ fragment representing the CTGF open reading frame obtained by $\mathrm{PCR}$ reaction using specific primers HO1 5'-CGGAATTCGCAGTGCCAACCATGACC-3' (SEQ ID NO:3) and HO2 5'-CCGAATTCTTAATGTCTCTCACTCTC-3' (SEQ ID NO:4). Hybridizations were performed using $1 \times 10^{6} \mathrm{cpm} / \mathrm{ml}$ of these probes labeled with $\left[\alpha-{ }^{32} \mathrm{P}\right] \mathrm{dCTP}$ by using a Random Primer DNA Labeling Kit (Boehringer Mannheim Biochemicals, Indianapolis Ind.). Autoradiography was performed at $-70^{\circ} \mathrm{C}$. for 6 to 72 hours by using $\mathrm{X}$-ray films and intensifying screens.

Isolation of Genomic Clones and Sequence Analysis

Genomic DNA was isolated from human skin fibroblasts as described previously (Sambrook et al., supra, 9:14-19). Using $4 \mu \mathrm{g}$ of genomic DNA as a template, a fragment of the CTGF 40 gene was amplified by $\mathrm{PCR}$ using primers $\mathrm{HO} 2$ and $\mathrm{HO} 3$ 5'-CGGAATTCCTGGAAGACACGTTTGGC-3' (SEQ ID NO:5). PCR products were digested with EcoR1 and subcloned into M13. Sequence analysis by the dideoxy chain termination method (Sanger et al., Proc Natl Acad Sci USA

45 74:5463-5467, 1977) using the SEQUENASE kit (U.S. Biochemical Corp) demonstrated $900 \mathrm{bp}$ fragment which had a $387 \mathrm{bp}$ intron in the middle portion. Using a Human Genomic Library in the Lambda FIX II vector (Stratagene) we screened approximately $1 \times 10^{6}$ recombinant phages with $\left[{ }^{32} \mathrm{P}\right]$-labeled 50900 bp genomic DNA fragment as probe and isolated 3 phage clones that contained the CTGF gene.

Luciferase Reporter Gene Assays

A fragment of the CTGF promoter containing nucleotides -823 to +74 from one of the human genomic clones was first cloned in the SacI-Xho1 cloning site of GL2-Basic vector (Promega). This construct (PO) was used as a template for PCR and deletion mutants were made with specific primers as follows: P1 contained nucleotides from -638 to +74 , $\mathrm{P} 2$ from -363 to $+74, \mathrm{P} 3$ from -276 to +74 , and $\mathrm{P} 4$ from -128 to +74 .

60 All deletion fragments were sequenced to insure no mutations had been introduced in the promoter fragments. NIH/3T3 cells were transfected in a 6-well plate with LIPOFECTIN reagent (Invitrogen Corp., Carlsbad Calif.) for 6 hours. Each transfection included $2 \mu \mathrm{g}$ of $\mathrm{pSV}-\beta$-Galactosidase vector 65 (Promega). Cells were incubated in serum-free DMEM with ITS (Collaborative Biomedical Products, Bedford Mass.) for 24 hours after transfection followed by the incubation with 
25

growth factors for 4 hours or 24 hours. Luciferase activity was measured by using Luciferase Assay System (Promega) and a LS6000SC scintillation counter (Beckman Coulter, Fullerton Calif.) using it in single photon monitor mode. To normalize for differences in transfection efficiency $\beta$-galactosidase activity was measured using a chemiluminescent assay using GALACTO-LIGHT (Tropix Inc., Bedford Mass.).

Preparation of Nuclear Extracts

Nuclear extracts were prepared as described by Abmayr and Workman (Current Protocols in Molecular Biology, vol 2, pp 12.1.1-12.1.9, Ausubel et al., Greene Publ and Wiley Interscience, New York, N.Y.). Briefly, cells were treated with hypotonic buffer (10 mM HEPES pH 7.9, $1.5 \mathrm{mM} \mathrm{MgCl}_{2}, 10$ $\mathrm{mM} \mathrm{KCl,} 0.2 \mathrm{mM}$ PMSF, 0.5 mMDTT), homogenized with 10 strokes of a glass dounce homogenizer and nuclei were isolated by centrifugation at $3300 \times \mathrm{g}$ for 15 minutes. Nuclear proteins were extracted by suspending the nuclei in an equal volume of extraction buffer ( $20 \mathrm{mM}$ HEPES pH7.9, 25\% glycerol, $1.5 \mathrm{mM} \mathrm{MgCl}_{2}, 0.8 \mathrm{M} \mathrm{KCl}, 0.2 \mathrm{mM}$ EDTA, $0.2 \mathrm{mM}$ PMSF and $0.5 \mathrm{mMDTT}$ ). The extract was dialyzed against 20 mM HEPES pH 7.9, 20\% glycerol, $100 \mathrm{mM} \mathrm{KCl,} 0.2 \mathrm{mM}$ EDTA, $0.2 \mathrm{mM}$ PMSF and $0.5 \mathrm{mM}$ DTT before use. Protein concentration was determined using the BCA protein assay regent (Pierce, Rockford I11.).

\section{Gel Mobility Shift Assays}

Fragments of the CTGF promoter were prepared by PCR or restriction endonuclease digestion of the promoter fragment. Double stranded oligonucleotides were prepared by annealing complementary single stranded oligonucleotides. All oligonucleotides and fragments were checked by electrophoresis in agarose gels or polyacrylamide gels. Radiolabeled fragments of the CTGF promoter were prepared by end-labeling with Klenow enzyme (Boehringer Manheim) and polynucleotide kinase (Boehringer Manheim). Labeled fragments were purified by electrophoresis in $2 \%$ agarose gels or $20 \%$ polyacrylamide gel before use in gel mobility shift assay. The binding reaction mixture contained $1 \mathrm{~g}$ of nuclear extract protein in $20 \mu \mathrm{l}$ of $10 \mathrm{mM}$ HEPES $\mathrm{pH} 7.9,5$ mM Tris, $50 \mathrm{mM} \mathrm{KCl}, 0.1 \mathrm{mM}$ EDTA, $1 \mu \mathrm{g}$ poly(dI-dC).poly (dI-dC) (Pharmacia, Peapack N.J.), 10\% glycerol, $300 \mu \mathrm{g} / \mathrm{ml}$ $\mathrm{BSA}$, and $10,000 \mathrm{cpm}\left[{ }^{32} \mathrm{P}\right]$ labeled DNA probe. Unlabeled competitor DNA was added and incubated at $4^{\circ} \mathrm{C}$. for 2 hours prior to adding the labeled probe. The labeled probe was incubated for one hour at $4^{\circ} \mathrm{C}$ in the reaction mixture. Electrophoresis was performed using $5 \%$ polyacrylamide gel with $50 \mathrm{mM}$ Tris, $0.38 \mathrm{M}$ glycine and $2 \mathrm{mM}$ EDTA.

Methylation Interference Assay

End-labeled fragments of double stranded oligonucleotides were prepared as described for the gel mobility shift assay. The oligonucleotides were methylated by dimethyl sulfate (Fisher Scientific) for 5 minutes at room temperature. DNA-protein binding and gel mobility shift assay were performed as described above using large amounts of labeled probe $(100 \mathrm{~K} \mathrm{cpm})$ and nuclear protein $(20 \mu \mathrm{g})$. DNA from shifted and non-shifted bands was purified and cleaved with piperidine (Fisher Scientific, Pittsburgh $\mathrm{Pa}$.), and the samples were electrophoresed on a polyacrylamide DNA sequencing gel. The sequences of the shifted and non-shifted fragments were compared with the intact probe sequenced using the same methods.

\section{EXAMPLE 8}

\section{Prolonged Induction Of CTGF mRNA By Short Term TGF- $\beta$ Exposure}

Most immediate early genes, such as c-fos and c-myc, that are induced by growth factors exhibit a short burst of expres-

\section{6}

sion even though the growth factor remains present in the media. In contrast, CTGF transcripts remain at high levels for over 24 hours after activation of the cells with TGF- $\beta$ (Igarashi et al., Mol Biol Cell 4:637-645, 1993). This example examines whether the long term elevation of CTGF transcripts was dependent on the continuous presence of TGF- $\beta$.

Confluent human skin fibroblasts were cultured in serum free DMEM supplemented by insulin, transferrin, and selenium (DMEM-ITS) for 24 hours prior to adding of TGF- $\beta$. After 1 hour exposure to TGF- $\beta$, cells were washed in PBS and replaced with DMEM-ITS followed by different periods of incubation. Specifically, confluent cultures of human skin fibroblasts were incubated with DMEM-ITS containing 5 $\mu \mathrm{g} / \mathrm{ml}$ of insulin, $5 \mu \mathrm{g} / \mathrm{ml}$ of transferrin and $5 \mathrm{ng} / \mathrm{ml}$ of selenium for 24 hours prior to the addition of TGF- $\beta$. After the treatment with $10 \mathrm{ng} / \mathrm{ml}$ of TGF- $\beta$ for 1 hour, cells were washed with PBS and incubated with DMEM-ITS for indicated time periods. Northern blot analysis revealed CTGF mRNA was strongly induced from 4 hours to 30 hours after TGF- $\beta$ removal (FIG. 2A).

The ability of TGF- $\beta$ to induce the CTGF transcript in the presence of several protein synthesis inhibitors was examined. FIG. 2B shows the effect of cycloheximide on induction of CTGF mRNA. Lane A and $\mathrm{H}$ are non-treated control cells at 4 hours and 24 hours, respectedly. Lane B. 4 hrs. Cyclo25 heximide (CHX) $(10 \mu \mathrm{g} / \mathrm{ml})$; Lane C, 4 hrs TGF- $\beta$ present for 1 hour during hour 1 of 2 of cycloheximide exposure; Lane E, same as B with RNA prepared 24 hours after addition of cycloheximide; Lane F, 24 hours TGF- $\beta(10 \mu \mathrm{g} / \mathrm{ml})$; Lane $\mathrm{G}$, same as D with RNA prepared 24 hours after addition of cycloheximide and 22 hours after removal of TGF- $\beta$.

As shown in FIG. 2B, a 1 hour stimulation by TGF- $\beta$ in the presence of cycloheximide was sufficient to induce CTGF mRNA 4 hours later as well as 24 hours later. Cycloheximide alone was able to increase CTGF mRNA 4 hours later, suggesting the possibility of mRNA stabilization as has been reported for cycloheximide induction of other transcripts such as c-fos and c-myc (Greenberg et al., Nature 311:433438, 1984; Kruijer et al., Nature 312:711-716, 1984). However, a report by Edwards and Mahadevan (EMBO J 11:24152424,1992 ) indicated that the protein synthesis inhibitors 40 cycloheximide and anisomycin, but not puromycin, could act to stimulate transcription of the c-fos and c-jun genes, therefore message stabilization is not the only possible mechanism of action for these compounds.

The ability of anisomycin and puromycin to inhibit TGF- $\beta$ 45 induction of CTGF transcripts was compared with that of cycloheximide as to the ability to elevate CTGF transcripts. FIG. 2C shows the effect of protein synthesis inhibitors on induction of CTGF mRNA. Cells were treated with puromycin or anisomycin for 4 hours. TGF- $\beta$ was added 1 hour after 50 the addition of protein synthesis inhibitor and cells were incubated for 3 hours prior to isolation of total RNA. CTGF transcripts were analyzed by northern blot.

Puromycin did not induce the CTGF mRNA at any of the concentrations tested up to $100 \mathrm{ttg} / \mathrm{mi}$, which is 10 fold higher than that needed to completely block protein synthesis in these cells. Even at this high concentration it had no effect on the ability of TGF- $\beta$ to induce the CTGF mRNA. In contrast, anisomycin did elevate CTGF transcripts (FIG. 2C) as was seen with cycloheximide although TGF- $\beta$ treatment still raised the level of CTGF mRNA in the presence of anisomy$60 \mathrm{cin}$.

These findings are similar to those reported by Edwards and Mahadevan (supra) where both c-fos and c-jun were induced by anisomycin or cycloheximide by themselves, but not by puromycin alone. These data strongly suggest TGF- $\beta$

65 directly regulates CTGF gene expression via a mechanism that is independent of protein synthesis and may be primarily acting at the level of transcription. 
EXAMPLE 9

\section{Isolation Of The Human CTGF Gene}

To elucidate the structure of the CTGF gene, a fragment of 5 the CTGF gene was first obtained using PCR. Four micrograms of genomic DNA prepared from human skin fibroblasts was used as a template and oligonucleotides, $\mathrm{HO} 2$ and HO3, were used as primers. After 30 cycles of reaction, a 900 $\mathrm{bp}$ fragment was recovered that was $390 \mathrm{bp}$ longer than pre- 1 dicted from the cDNA sequence. Nucleotide sequence analysis of this fragment (HO900) revealed the presence of a 387 bp intron in the middle portion of the fragment. Using HO900 as a probe, 3 phage clones were from the human genomic library that contained a $4.3 \mathrm{~kb}$ Xbal fragment which represented the entire coding sequence of the CTGF gene and a large portion of the putative promoter region. As shown in FIG. 1A, the CTGF gene has 5 exons and 4 introns. A TATA sequence is present 24 nucleotides upstream of the mRNA cap site, determined by oligonucleotide primer extension. The consensus sequence of a CArG box, which is the inner core of the serum response element (SRE) characterized by $\mathrm{CC}(\mathrm{A} / \mathrm{T})_{6} \mathrm{GG}$ (SEQ ID NO:14), is present between nucleotide position -380 to -390 . Other potential regulatory elements are also present including a CAT box, two $\mathrm{Sp} 1$ sites and two AP-1 sites. Furthermore, the CTGF promoter has a NF-1 like site, (TGGN 6 GCCAA) (SEQ ID NO:13), between positions -194 and -182 , and TGF- $\beta$ inhibitory element like sequence (GNNTTGGTGA) (SEQ ID NO:12) between positions -119 and -128 . Both of these elements have single base differences from the reported consensus sequences (Edwards and Heath, Molecular Aspects of Cellular Regulation: Hormonal Control Regulation of Gene Transcription, Cohen and Foulkes, eds. Elsevier/North Holland Biomedical Press, Amsterdam, 16: pp 333-347, 1991). DNA sequence comparison showed that the human CTGF promotor has an $80 \%$ sequence identity to the murine fisp- 12 promoter in the region 300 nucleotides 5 'of the transcription start site (FIG. 1B). Further upstream regions exhibit much less similarity in DNA sequence.

\section{EXAMPLE 10}

\section{Studies on the CTGF Promoter}

To test whether the $5^{\prime}$ nontranslated region of CTGF gene 45 functions as a TGF- $\beta$ inducible promoter, a fusion gene was constructed containing the CTGF promoter (nucleotides -823 to +74 ) and the coding region of the firefly luciferase gene in the vector pGL2-basic. Luciferase activity was tested in a transient transfection assay using NIH/3T3 cells. This construct conferred a 15-30 fold induction of luciferase activity after 24 -hour stimulation by TGF- $\beta$ compared with control cultures. As seen at the level of the CTGF mRNA, other growth factors such as PDGF, EGF and FGF stimulated only a 2-3 fold induction of luciferase activity under identical conditions (Table 1).

TABLE 1

\begin{tabular}{|c|c|c|c|c|}
\hline \multicolumn{5}{|c|}{$\begin{array}{l}\text { CELL TYPE AND GROWTH FACTOR REGULATION OF } \\
\text { THE CTGF PROMOTER } \\
\text { RELATIVE FOLD INDUCTION OF LUCIFERASE ACTIVITY } \\
\text { AFTER GROWTH FACTOR TREATMENT }\end{array}$} \\
\hline CELL TYPE & TGF- $\beta$ & PDGF & FGF & $\mathrm{EGF}$ \\
\hline $\mathrm{NIH} / 3 \mathrm{~T} 3$ & 25.7 & 2.9 & 3.3 & 1.4 \\
\hline $\mathrm{HSF}$ & 9.2 & 2.4 & 3.1 & 2.2 \\
\hline VSMC & 9.8 & ND & $\mathrm{ND}$ & ND \\
\hline
\end{tabular}

TABLE 1-continued

\begin{tabular}{|c|c|c|c|c|}
\hline \multicolumn{5}{|c|}{$\begin{array}{l}\text { CELL TYPE AND GROWTH FACTOR REGULATION OF } \\
\text { THE CTGF PROMOTER } \\
\text { RELATIVE FOLD INDUCTION OF LUCIFERASE ACTIVITY } \\
\text { AFTER GROWTH FACTOR TREATMENT }\end{array}$} \\
\hline CELL TYPE & TGF- $\beta$ & PDGF & $\mathrm{FGF}$ & $\mathrm{EGF}$ \\
\hline HBL100 & 1.1 & ND & 1.3 & \\
\hline HEPG2 & 1.3 & ND & 1.4 & 1.8 \\
\hline \multicolumn{5}{|c|}{$\begin{array}{l}\text { ND Not Detemiined } \\
\text { HSF Human foreskin fibroblasts (primary) } \\
\text { VSMC Fetal bovine aortic smooth muscle cells (primary) } \\
\text { HBL } 100 \text { Human breast epithelial cell line (nontumorigenic) } \\
\text { HEP G2 Human Hepatic epithelial cell line (nontumorigenic) } \\
\text { (A CTGF gene fragment extending from nucleotides position }-823 \text { to }+74 \\
\text { was inserted in the pGL2basic vector. Plasmids were transfected with lipo- } \\
\text { fectin for } 6 \text { hours and cells were incubated in DMEMITS for } 16 \text { hours prior } \\
\text { to the addition of growth factors. After a } 24 \text { hour incubation cell extracts } \\
\text { were prepared and luciferase activity measured. Luciferase activities were } \\
\text { normalized by measuring galactosidase activity expressed from a cotrans- } \\
\text { fected lacZ expression vector, pSV } \beta \text { ctosidase activity expressed from a } \\
\text { cotransfected lacZ expression vector, pSVgalactosidase vector and compared } \\
\text { between growth factor treated cells and nontreated cells. These experiments } \\
\text { were repeated } 4 \text { times with similar observations. A representative experiment } \\
\text { is shown). }\end{array}$} \\
\hline
\end{tabular}

When this promoter fragment was cloned in the reverse orientation $(+74$ to -823$)$, only basal levels of luciferase activity were detected and this level was unaffected by TGF- $\beta$ or other growth factor treatment of the cells. The same pattern of growth factor induction was observed when human skin 30 fibroblasts were used instead of NIH3T3 cells (Table 1). $\mathrm{TGF}-\beta$ did not induce luciferase activity in several epithelial cell lines (Table 1 ), demonstrating that TGF- $\beta$ regulation of the CTGF gene is cell type specific. The lack of any response by the epithelial cells is not due to a lack of a TGF- $\beta$ response 35 as the growth of these cells is inhibited by TGF- $\beta(10 \mathrm{ng} / \mathrm{ml})$. The induction of luciferase activity under the control of the CTGF promoter only required a brief exposure of the cells to TGF- $\beta$ as a 1 hour treatment of the cells with TGF- $\beta$ gives nearly the same fold induction at 4 and 24 hours as cells

40 continuously exposed to TGF- $\beta$ (Table 2 ). These results confirm the data from the Northern blots described previously and demonstrate that transcriptional regulation plays a primary role in the control of CTGF gene expression by TGF- $\beta$.

\section{5}

TABLE 2

SHORT TERM TGF-B EXPOSURE STIMULATES LONG TERM CTGF PROMdTER ACTIVITY ${ }^{1}$

\section{0}

\begin{tabular}{lcc} 
& \multicolumn{2}{c}{ Luciferase Activity } \\
\cline { 2 - 3 } Duration of TGF- $\beta$ exposure & 4 Hours & 24 Hours \\
\hline Continuous & 3.8 & 21 \\
\#hour & 3.5 & 19 \\
\hline
\end{tabular}

${ }^{1}$ Fold induction of Luciferase activity determined as described in Table 1 legend and EXAMPLE 7.

NIH/3T3 cells were used for these experiments.

\section{Identification Of The Promoter Element Required For TGF- $\beta$ Induction}

65 To determine which region of the promoter sequence is responsible for the induction by TGF- $\beta$, deletion mutants of the CTGF promoter were constructed using PCR primers 
29

designed to delete the known transcription factor consensus elements. Regions of the promoter beginning at the most $5^{\prime}$ region and moving toward the transcription start site were systematically deleted (FIG. 3A). Removal of the region of the promoter down to base -363 which included an AP1 site and the CArG box had no significant effect on the TGF- $\beta$ induction of luciferase activity. Approximately a $30 \%$ reduction was seen when the second AP-1 was deleted ( -363 to $-276)$ although the fold induction by TGF- $\beta$ was still high (20 fold). Removal of the NF-1 like site in the P4 construct ( -276 to -128 ) eliminated the TGF- $\beta$ inducibility of the promoter suggesting that this region contained the TGF- $\beta$ response element. Taking advantage of two BsmI sites we deleted the nucleotides from -162 to -110 leaving the remaining portions of the promoter intact. This construct exhibited a complete loss of TGF- $\beta$ inducibility demonstrating that the sequence between positions -162 and -128 is essential for the TGF- $\beta$ induction of luciferase activity. This region contains the TGF- $\beta$ inhibitory element (TIE)-like site and is bordered by the NF-1 like site that others have reported plays a role in TGF- $\beta$ regulation of $\alpha 2(\mathrm{I})$ collagen gene expression (Oikarinen, Hatamochi, and De Crombrugghe, J Biol Chem 262:11064-11070, 1987) and type 1 plaminogen activator inhibitor (PAI-1) gene expression (Riccio et al., Mol Cell Biol 12:1846-1855, 1992).

A fusion gene was constructed placing the nucleotides from positions -275 to -106 of the CTGF promoter upstream from an SV40 enhancerless promoter controlling a luciferase gene to determine whether this region of the promoter was sufficient to confer TGF- $\beta$ inducibility (FIG. 3B). The SV40 enhancerless promoter was not regulated by TGF- $\beta$. However, the promoter containing the CTGF sequences -275 to -106 conferred a nearly 9 fold induction after TGF- $\beta$ treatment. Inversion of the fragment resulted in a little stimulation of luciferase activity after TGF- $\beta$ treatment. These data confirm that sites in the CTGF promoter between nucleotides -275 and -106 can act as TGF- $\beta$ regulator elements.

A series of competitive gel shift and methlylation interference assays were performed to delineate the region of this potion of the CTGF promoter that was binding to nuclear proteins. Initially competitive gel shifts were used to delineate which region of the sequence between positions -205 to -109 was a target for protein binding. A diagram of the probe 4 and the various competitor fragments is illustrated in (FIG. 4). The results of these studies demonstrate that any fragment that contained the NH3 region $(-169$ to -149$)$ acted as a specific competitor for the labeled promoter fragment containing bases -204 to -109 (FIG. 4). This region is located between the NF-1 like and TIE like sites. Oligonucleotide fragments that contained only the TIE like region or the NF-1 like region without the $\mathrm{NH} 3$ region did not compete in the gel shift assay.

To further delineate the regulatory element, methylation 5 interference assays were performed. A fragment of the promoter from positions -275 to -106 was used initially. The results of these studies indicate that neither the NF-1 like site of the TIE element appear to be interacting with any nuclear proteins present in either control or TGF- $\beta$ treated cells con- 6 firming the gel shift competition data. However, a region between these sites from positions -157 to -145 contained several $G$ residues that were not methylated in the shifted bands suggesting that this region was the nuclear proteinbinding site (FIG. 5A). A smaller fragment of the region (nucleotides -169 to -139 ) was then analyzed to give better resolution of the important $\mathrm{G}$ residues (FIG. 5B). The data
30

from this analysis confirmed that of the larger fragment and map $G$ residues that lie within the sequence determined by competition gel shifts.

To better characterize the actual TGF- $\beta$ reactive site, the ability of the intact sequence and several deletions to compete for protein binding was compared in the gel shift assay (FIG. 6). These data confirm the results of the methlylation interference assays and suggest that the region of the promoter from positions -159 to -143 contains at least a portion of the 0 cis regulator element involved in TGF- $\beta$ regulation of CTGF gene expression.

Point mutations were made in the region of the sequence believed to be involved in the TGF- $\beta$ induction and tested these promoters in our luciferase reporter construct (FIG. 7).

15 Two point mutations were tested and both reduced the inducibility of the gene by TGF- $\beta$. One mutation reduced the induction by $25 \%$ from control and the other by $80 \%$. Neither had any effect on basal level of expression compared to control native sequence.

Point mutations were constructed by synthesis of oligonucleotides containing the desired base change and taking advantage of the two BsmI sites in the CTGF promoter. All constructs were confirmed by nucleotide sequence analysis to demonstrate that only the desired base change occurred and that all of the other nucleotide sequence was identical to the normal promoter. Assays were performed as described above for other CTGF promoter-luciferase constructs using NIH/ $3 \mathrm{~T} 3$ cells as targets. The data presented in the Table in FIG. 7 is from a single experiment with duplicate assays for each 30 experimental condition. The experiment was run several times to confirm the results. These data demonstrate that a single mutation in this region of the promoter can reduce the TGF- $\beta$ induction by $85 \%$, to less than $15 \%$ of the normal gene. These data demonstrate that the sequence identified is essential for the TGF- $\beta$ induction of the CTGF gene.

\section{EXAMPLE 12}

TGF- $\beta$ Stimulates Anchorage Independent Growth Via A CTGF Dependent Pathway

Inhibition of TGF- $\beta$ Induced CTGF Gene Expression by Elevation of cAMP Levels

Both herbimycin and phorbol esters were utilized to determine if either tyrosine kinases or protein kinase $\mathrm{C}$ had any role in the regulation of CTGF gene expression induced by TGF- $\beta$. These studies were performed using the CTGF promoter $(-823$ to +74$)$ luciferase reporter construct transfected into NIH/3T3 cells.

$\mathrm{NIH} / 3 \mathrm{~T} 3$ cells were grown to $50 \%$ confluence in DMEM/ $10 \%$ FCS. They were all transfected with PO CTGF promoter (nucleotides position -823 to +74 ) driving the expression of the pGL2 basic vector firefly luciferase using LIPOFECTIN as described above in EXAMPLE 7. After 24 hours in DMEM/ITS media the inhibitors were added. All of the agents were added to the cultures 2 hours prior to the addition of $10 \mathrm{ng} / \mathrm{ml}$ TGF- $\beta$. The cells were incubated 24 hours and the luciferase activity determined using the Tropix luciferase assay kit and a Beckman scintillation counter equipped with a single photon monitor. In a related experiment PMA was added to the cells for 24 hours prior to TGF- $\beta$ to deplete protein kinase $C$. This also had no effect on the ability of TGF $-\beta$ to induce luciferase activity under the control of the CTGF promoter. Also, as a control experiment for the herbi65 mycin studies, the activity of this agent to inhibit PDGF induced cell division was examined. Confluent density arrested monolayers of NIH/3T3 cells were treated with the 
31

indicated concentrations of herbimycin for 2 hours prior to addition of recombinant PDGF BB. The number of cells was determined by trypsinization and counting 24 hours after the addition of PDGF. The mitotic index represents the percent of cells that underwent mitosis.

Neither of these compounds had any effect on the ability of TGF- $\beta$ to induce CTGF gene expression, nor did they modulate the basal level of CTGF gene expression in the target cells. However, both cholera toxin or $8 \mathrm{Br}$-c AMP were potent inhibitors of the TGF- $\beta$ induction of the CTGF gene (FIG. 8A).

These data indicate that neither tyrosine kinases or protein kinase $\mathrm{C}$ is part of the signal transduction pathway leading to CTGF gene induction controlled by TGF- $\beta$. Also, cyclic nucleotide regulated proteins do not appear to be a part of the TGF- $\beta$ pathway for regulation of CTGF gene expression. However, elevation of cAMP levels in the cell abolishes the TGF- $\beta$ induction of CTGF gene expression. In a related experiment we find that the $\mathrm{cAMP}$ or cholera toxin can be added up to 8 hours after addition of TGF- $\beta$ and it is still effective in blocking the expression of the CTGF gene. This suggests that the action of the cAMP is distal from the receptor and may be affecting transcription factor binding to the CTGF promoter.

cAMP Does Not Block All of the Actions of the TGF- $\beta$ on Fibroblastic Cells

The four panels shown in FIG. $8 \mathrm{~B}$ are photomicrographs of the NIH/3T3 cells used in the above experiments which were Control: No Additons; TGF- $\beta$ :TGF- $\beta$ (10 ng/ml); cAMP: $8 \mathrm{Br}$ cAMP $(1000 \mu \mathrm{M}) ; \mathrm{cAMP}+\mathrm{TGF}-\beta$ : $8 \mathrm{BrcAMP}(1000 \mu \mathrm{M})$ and TGF- $\beta(10 \mathrm{ng} / \mathrm{ml})$ prior to determination of luciferase activity. These data indicate that while cAMP causes dramatic changes in the morphological appearance of the NH13T3 cells, TGF- $\beta$ addition to these cells induces a morphological appearance in these cells which was similar, if not identical, to control cells treated with TGF- $\beta$. Thus, although cAMP can block TGF- $\beta$ induction of CTGF gene expression it has no effect on the biochemical events which regulate the observed changes in morphology seen in these monolayer cultures. These results demonstrate that there are multiple components in the action of TGF- $\beta$ on fibroblastic cells which can be differentially blocked by cAMP. No significant difference was detected in the culture with respect to total cellular protein content or expression of an SV40/ $\beta$-galactosidase control reporter gene indicating that the changes were not due to toxic effects of the cAMP. Cholera toxin treatment induced a morphology similar to that seen in the $8 \mathrm{Br}$ cAMP treated cells which was reversed by addition of TGF- $\beta$.

Inhibition of TGF- $\beta$ Induced Anchorage Independent Growth by cAMP and its Reversal by rCTGF

Because of the results of the previous studies, experiments were performed to determine whether cAMP would block TGF- $\beta$ induced anchorage independent growth. Initially the effects of $8 \mathrm{Br}$ cAMP, $8 \mathrm{Br}$ cGMP and cholera toxin on the ability of TGF- $\beta$ to induce anchorage independent growth of NRK cells were tested. Anchorage independent growth assays were performed essentially as described by Guadagna and Assoian (J Cell Biol 115:1419-1425, 1991). Briefly NRK cells normally maintained as monolayer cultures were plated on an agarose layer in DMEM $/ 10 \% \mathrm{FCS}$ containing $5 \mathrm{ng} / \mathrm{ml}$ EGF. TGF- $\beta$ or CTGF was added and the cells incubated for 72 hours. DNA synthesis is then determined by labeling for 24 hours with $\left[{ }^{3} \mathrm{H}\right]$-thymindine $(2 \mu \mathrm{Ci} / \mathrm{ml})$ the cells harvested and processed by TCA precipitation etc. Inhibitors were added at the same time as the growth factors and remained present for the duration of the experiment (FIG. 8C). (Abbreviations: Cholera toxin (CTX)).

As seen in FIG. 8C, both 8Br cAMP and cholera toxin were effective inhibitors of growth in this assay while $8 \mathrm{Br}$ cGMP
32

had no effect at concentrations up to $10 \mathrm{mM}$. Because expression of the CTGF gene was blocked by elevation of cAMP levels in the cells, an experiment was performed to determine whether rCTGF could overcome the inhibition. As seen in the left panel in FIG. 8B addition of rCTGF to NRK cells does not stimulate anchorage independent growth and therefore does not substitute for TGF- $\beta$. However, addition of the same amounts of rCTGF to cells treated with TGF- $\beta$ and inhibited with either $8 \mathrm{Br}$ cAMP or cholera toxin overcomes the inhibition and allows the cells to grow at a rate comparable to those treated with TGF- $\beta$ in the absence of cAMP or cholera toxin (far right panel). These studies suggest a direct link between the production of CTGF and the ability of NRK cells to grow in suspension. They also demonstrate that while $\mathrm{TGF}-\beta$ can induce certain effects in fibroblasts in the presence 5 of elevated levels of cAMP they are not sufficient to allow for anchorage independent growth. Also, since CTGF alone is not sufficient to stimulate this biological response it is not a substitute for all of TGF- $\beta$ 's actions on fibroblasts. These results demonstrate there are both CTGF dependent and 20 CTGF independent effects induced by TGF- $\beta$ in target cells (NRK) that act synergistically to allow for a specific cellular response (anchorage independent growth).

\section{EXAMPLE 13}

Inhibition Of TGF- $\beta$ Induced Granulation Tissue Formation By Agents That Elevate cAMP Levels

TGF- $\beta$ has been shown to induce fibrosis in several animal 30 model studies. For example, one group injected 400 to $800 \mathrm{ng}$ of TGF- $\beta$ into the subdermal space in the back of neonatal mice. When TGF- $\beta$ is injected once a day for three days in a row, a large area of fibrotic tissue forms (Roberts et al., Proc Natl Acad Sci USA 83:4167, 1986). The present example shows comparative studies with TGF- $\beta$ and CTGF and the results showed that CTGF induced the formation of connective tissue which is very similar, if not identical to that formed in response to TGF- $\beta$. Other growth factors such as PDGF or EGF do not induce tissue similar to TGF- $\beta$, indicating that CTGF may be responsible for the formation of the tissue 40 induced by TGF- $\beta$ injection.

Because the results in Example 12 showed that cAMP levels could block the induction of CTGF in the cultured cells, it was of interest to determine whether elevation of cAMP levels in cells in an animal could block the action of TGF- $\beta$ in 45 vivo. Using the injection model described above and in Roberts et al. (supra) the following experiment was performed. Neonatal mice were injected once a day for three days in a row with either: TGF- $\beta(400 \mathrm{ng})$; cholera toxin (100 ng); TGF- $\beta$ $(400 \mathrm{ng})$ and cholera toxin (100 ng); or saline. Three mice 50 were used in each group. After injected tissue was prepared using standard histological methods, the area of injection was examined by light microscopy after staining with hematoxylin and eosin.

As expected, saline injections had no effect on the type of ${ }_{55}$ tissue present in the murine skin and TGF- $\beta$ injections induced a large amount of new connective tissue which resembled granulation tissue. This tissue contained increased numbers of fibroblasts and increased amounts of collagen and other matrix components. Injection of cholera toxin alone caused no stimulation of granulation tissue formation. Co-

60 injection of TGF- $\beta$ and cholera toxin also showed no formation of granulation tissue demonstrating that the cholera toxin blocked the TGF- $\beta$ induced formation of granulation tissue. These results indicate the therapeutic utility of agents that block the production or action of CTGF for use as anti-fibrotic 65 drugs.

All references cited herein are hereby incorporated by reference in their entirety. 
US 7,384,634 B2

SEQUENCE LISTING

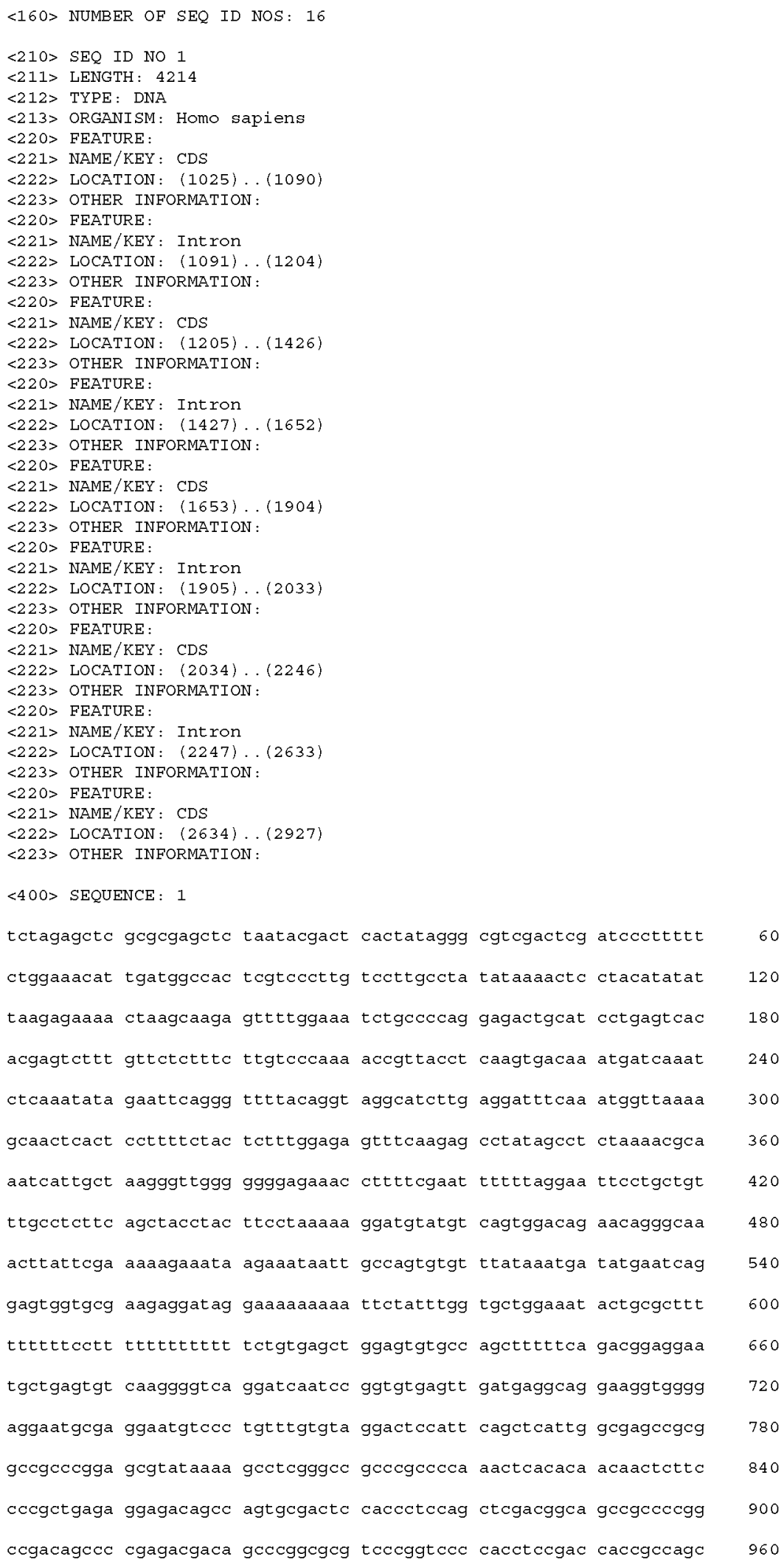




\section{US 7,384,634 B2}

- continued

getccaggec ecgegetece egetcgecge cacegegece tecgetcege ecgeagtgec

aacc atg acc gec gec agt atg gge ccc gtc cgc gtc gec ttc gtg gtc Met Thr Ala Ala Ser Met Gly Pro Val Arg Val Ala Phe Val Val

$105010 \quad 15$

ctc ctc gec etc tge age cgg gtaagcgecg ggagcceceg etgeggecgg

Leu Leu Ala Leu Cys Ser Arg 20

cggctgecag ggagggacte ggggecggec ggggagggeg tgegegcega cegagegecg

ctgaccgece tgtcetcect geag ecg gec gte gge cag aac tgc age ggg Pro Ala Val Gly Gln Asn Cys Ser Gly

25

ceg tgc cgg tgc ecg gac gag ecg geg ceg egc tgc ecg geg gge gtg Pro Cys Arg Cys Pro Asp Glu Pro Ala Pro Arg Cys Pro Ala Gly val
35
45

agc ctc gtg etg gac gge tgc gge tgc tgc cgc gtc tgc gcc aag cag Ser Leu Val Leu Asp Gly Cys Gly Cys Cys Arg Val Cys Ala Lys Gln 50 55 60

ctg ggc gag ctg tgc acc gag cgc gac $\mathrm{Ccc}$ tgc gac ccg cac aag ggc Leu Gly Glu Leu Cys Thr Glu Arg Asp Pro Cys Asp Pro His Lys Gly

$$
65070 \quad 75
$$

ctc ttc tgt gac ttc ggc tcc ccg gcc aac cgc aag atc ggc gtg tgc Leu Phe Cys Asp phe Gly Ser Pro Ala Asn Arg Lys Ile Gly Val Cys

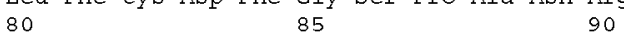

1020

1069

1120

1180

1231

1279

1327

1375

1423

1476

1536

1596

1655

1703

1799

1847

1895

1944

2004

2057

2105 


\section{US 7,384,634 B2}

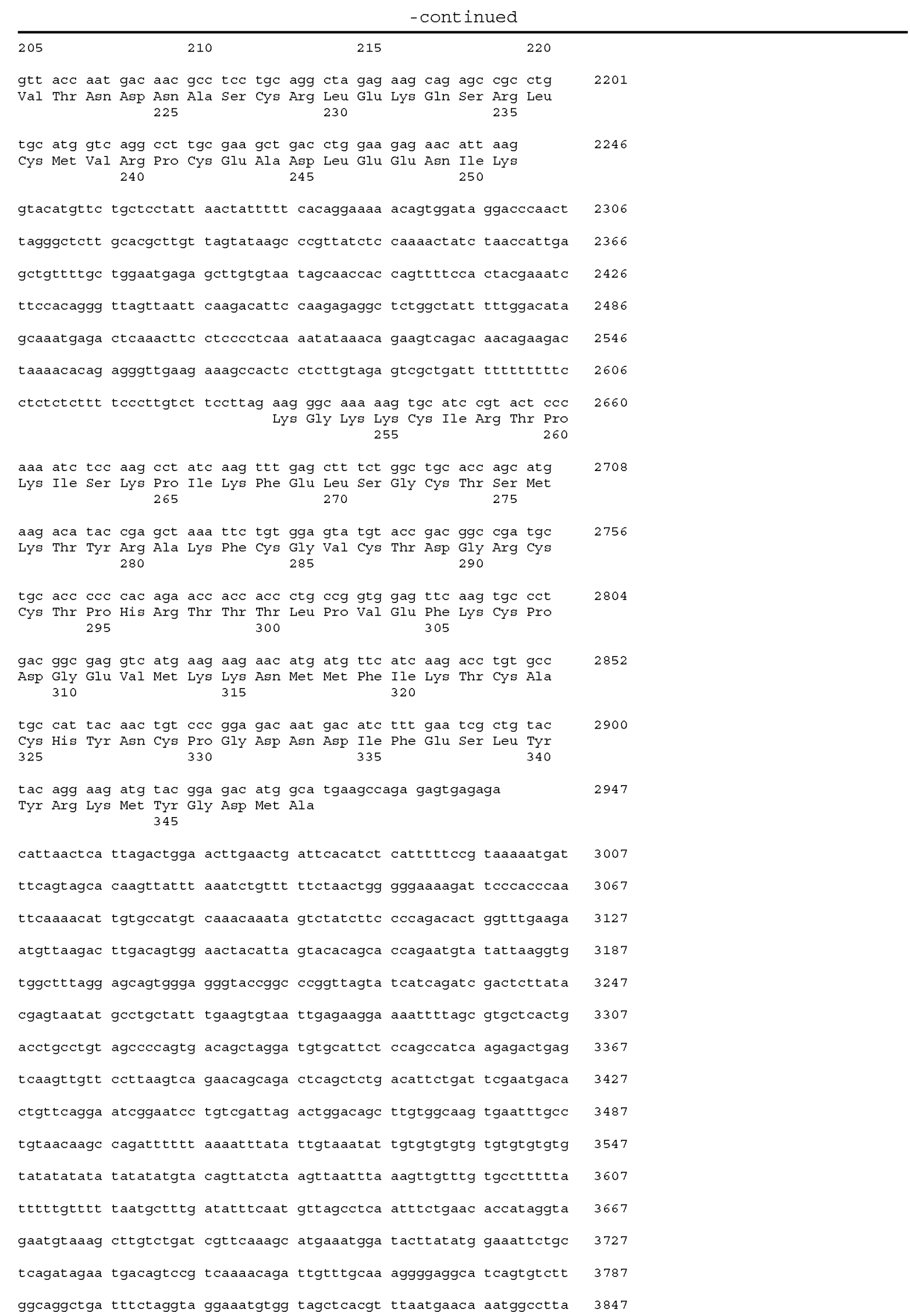


- continued

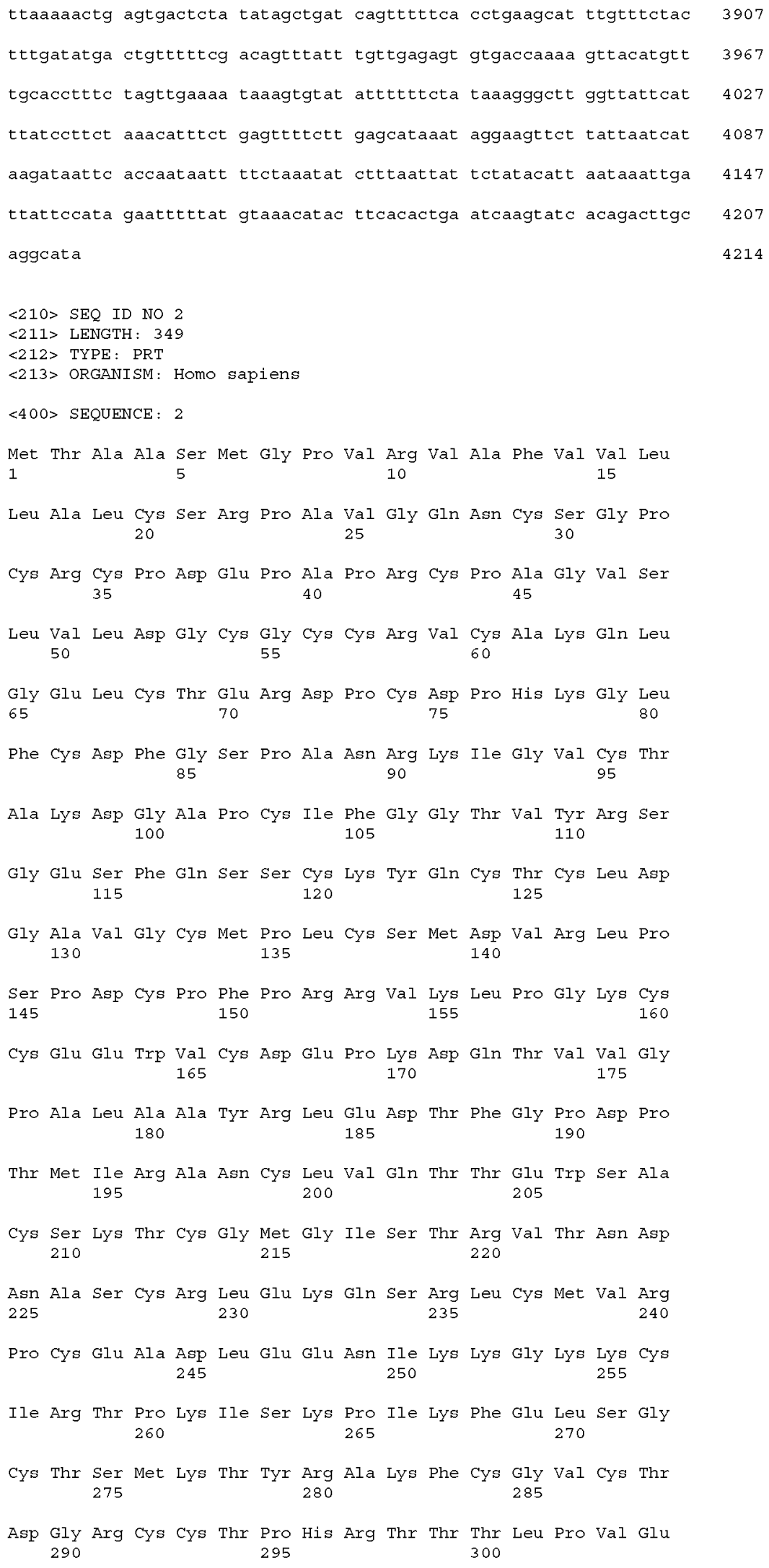




\section{US 7,384,634 B2}

- continued

Phe Lys Cys Pro Asp Gly Glu val Met Lys Lys Asn Met Met Phe Ile

$\begin{array}{llll}305 & 310 & 315 & 320\end{array}$

Lys Thr Cys Ala Cys His Tyr Asn Cys Pro Gly Asp Asn Asp Ile Phe

$325 \quad 330 \quad 335$

Glu Ser Leu Tyr Tyr Arg Lys Met Tyr Gly Asp Met Ala

$340 \quad 345$

$<210\rangle$ SEQ ID NO 3

$<211>$ LENGTH : 26

$<212>$ TYPE : DNA

$<213>$ ORGANISM: Artificial sequence

$<220>$ FEATURE:

$<223>$ OTHER INFORMATION: PCR primer

$<400>$ SEQUENCE : 3

cggattcge agtgccaacc atgacc

$<210>$ SEQ ID NO 4

$<211>$ LENGTH : 26

$<212>$ TYPE: DNA

$<213>$ ORGANISM: Artificial sequence

$<220\rangle$ FEATURE:

$<223>$ OTHER INFORMATION: PCR primer

$<400\rangle$ SEQUENCE: 4

cegaatete aatgtctetc actctc

$<210\rangle$ SEQ ID NO 5

$<211>$ LENGTH : 26

$<212>$ TYPE: DNA

$<213>$ ORGANISM: Artificial sequence

$<220\rangle$ FEATURE:

$<223>$ OTHER INFORMATION: PCR primer

$<400>$ SEQUENCE : 5

cggaattcct ggaagacacg tttggc

$<210\rangle$ SEQ ID NO 6

$<211>$ LENGTH : 840

$<212>$ TYPE: DNA

$<213>$ ORGANISM: Homo sapiens

$<400>$ SEQUENCE: 6

tctagagctc gegcgagctc taatacgact cactataggg cgtcgactcg atccettett

ctggaacat tgatggecac tcgtccettg tcctgceta tataaactc ctacatatat

taagagaaa ctaagcaaga gttttggaaa tctgccccag gagactgcat cetgagtcac

acgagtctt gttctcttc ttgtcccaa accgttacct cagtgacaa atgatcaat

ctcaatata gaattcaggg ttttacaggt aggcatcttg aggatttcaa atggttaaa

gcaactcact cetttctac tcttggaga gttcaagag cetatagcet ctaaacgca

aatcattgct aagggttggg ggggagaaac ctttcgaat tttttaggaa ttcctgctgt

tgcctctc agctacctac ttcctaaaa ggatgtatgt cagtggacag aacagggcaa

tgctgagtgt caaggggtca ggatcaatcc ggtgtgagtt gatgaggcag gaaggtgggg 


\section{US 7,384,634 B2}

- continued

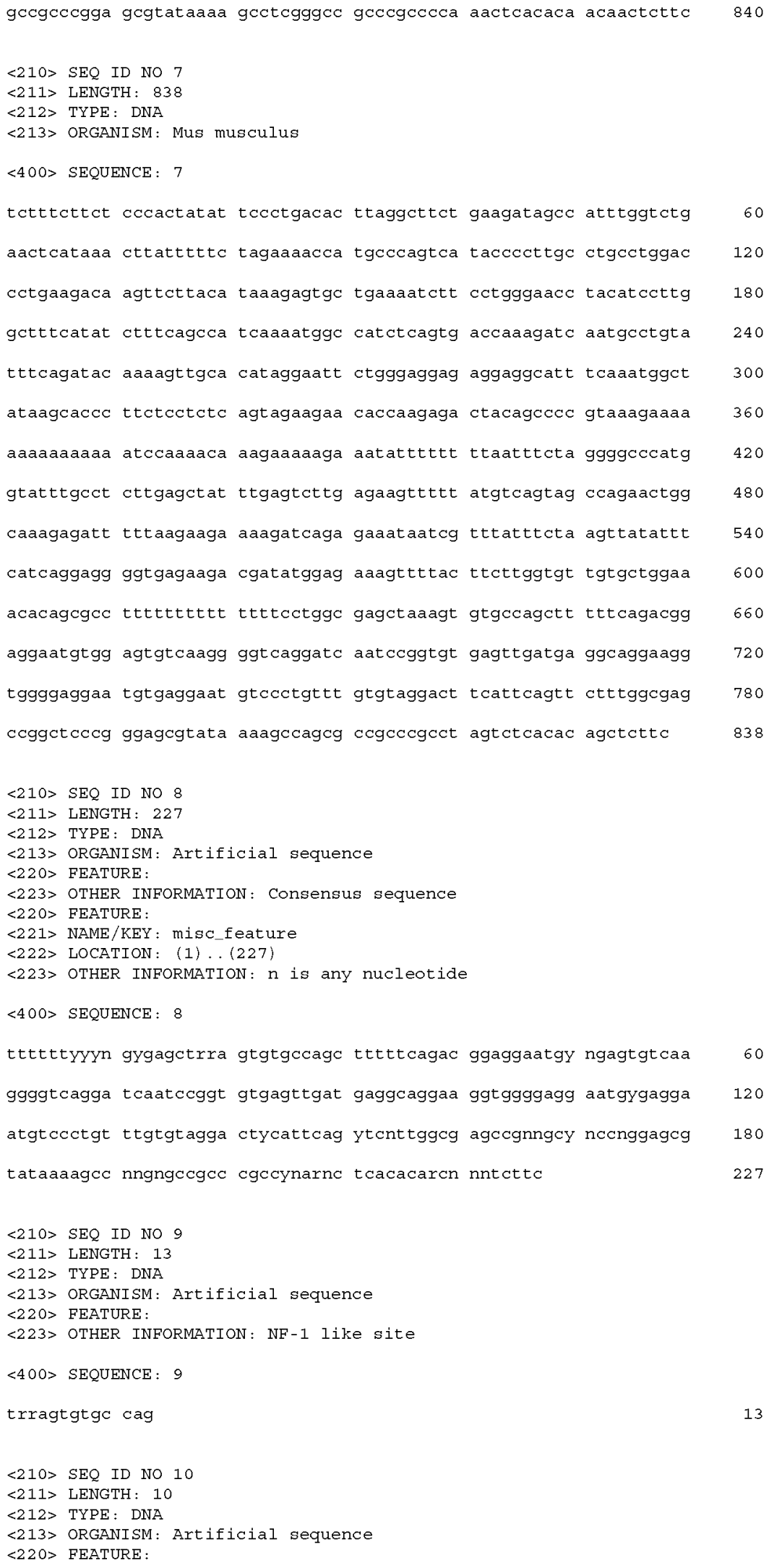


US 7,384,634 B2

- continued

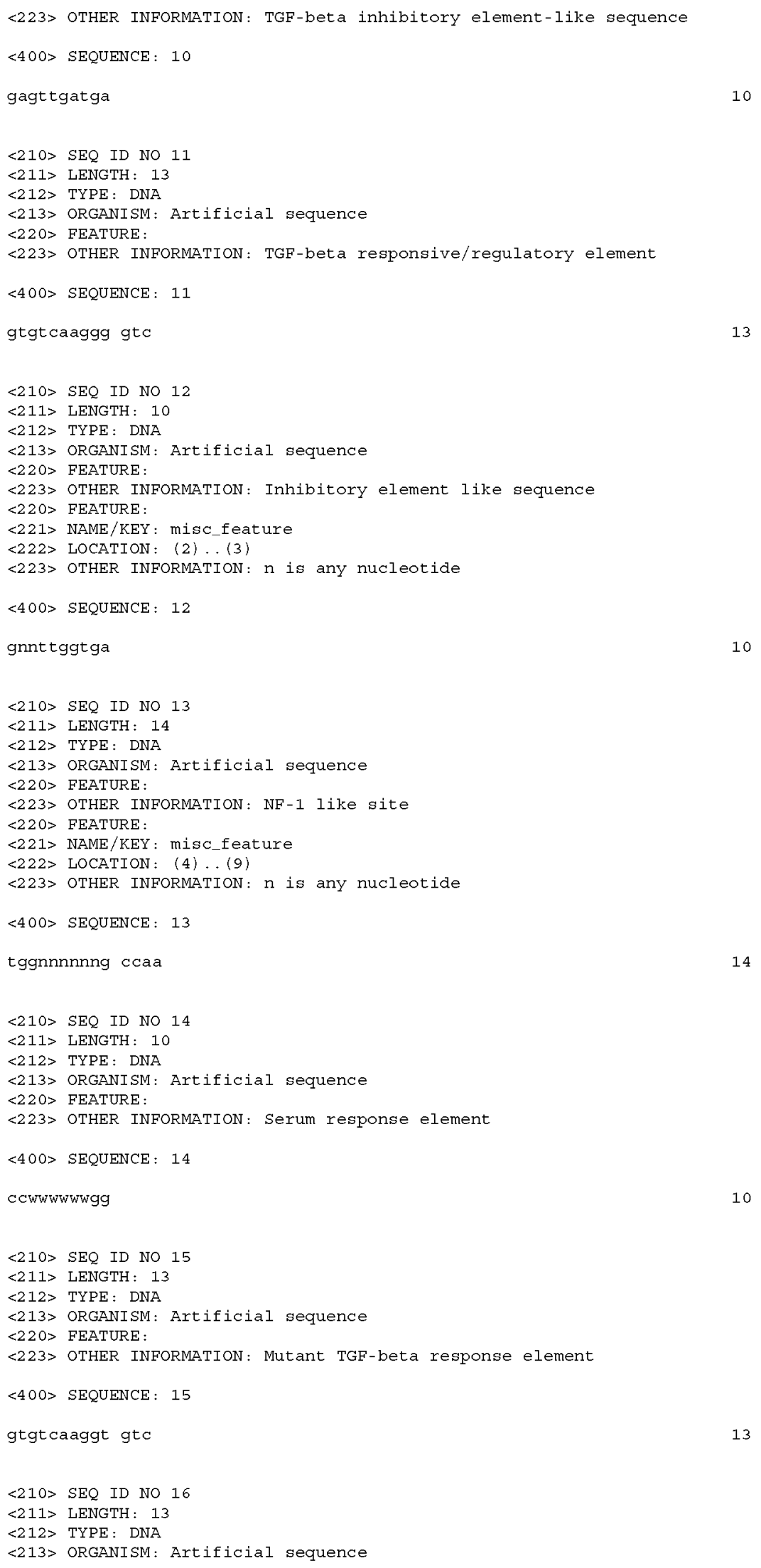


US 7,384,634 B2

- continued

$<220>$ FEATURE

$<223>$ OTHER INFORMATION: Mutant TGF-beta response element

$<400>$ SEQUENCE : 16

gtgttaaggg gtc

13

The invention claimed is:

1. A method of treating a disorder selected from the group consisting of pulmonary fibrosis, kidney fibrosis, tumor formation and growth, and glaucoma comprising administering a therapeutic amount of an agent that modulates CTGF level or activity to a subject in need thereof, wherein the agent is an antibody which selectively binds to CTGF and does not crossreact with $\mathrm{PDGF}$.

2. A method for ameliorating a disorder selected from the group consisting of pulmonary fibrosis, kidney fibrosis, tumor formation and growth, and glaucoma comprising treating a subject having the disorder, at the site of the disorder, with a CTGF reactive agent, wherein the reactive agent com-
10 prises an antibody which selectively binds to CTGF and does not cross-react with PDGF.

3. The method of claim $\mathbf{1}$ or $\mathbf{2}$, wherein the antibody is a monoclonal or a polyclonal.

5 4. The method of claim 1 or 2 , wherein the disorder is pulmonary fibrosis.

5. The method of claim $\mathbf{1}$ or $\mathbf{2}$, wherein the disorder is kidney fibrosis.

6. The method of claim 1 or $\mathbf{2}$, wherein the disorder is tumor formation and growth.

7. The method of claim $\mathbf{1}$ or $\mathbf{2}$, wherein the disorder is glaucoma. 